Cornell Law Library

Scholarship@Cornell Law: A Digital Repository

Cornell Law Faculty Publications

Faculty Scholarship

$1-1-1994$

\title{
Facial Challenges to State and Federal Statutes
}

Michael C. Dorf

Cornell Law School, michaeldorf@cornell.edu

Follow this and additional works at: http://scholarship.law.cornell.edu/facpub

Part of the Constitutional Law Commons

\section{Recommended Citation}

Dorf, Michael C., "Facial Challenges to State and Federal Statutes" (1994). Cornell Law Faculty Publications. Paper 110.

http://scholarship.law.cornell.edu/facpub/110

This Article is brought to you for free and open access by the Faculty Scholarship at Scholarship@Cornell Law: A Digital Repository. It has been accepted for inclusion in Cornell Law Faculty Publications by an authorized administrator of Scholarship@Cornell Law: A Digital Repository. For more information, please contact jmp8@cornell.edu. 
Content downloaded/printed from HeinOnline (http://heinonline.org) at Tue Nov 25 18:41:01 2008

Citation: 46 Stan. L. Rev. 1993-1994

From the HeinOnline License Agreement:

Licensees are granted a personal, non-exclusive, non-transferable, limited license to access the on-line, electronic archive of journals and other materials provided by HeinOnline (the 'Database'), and to download or print any portion or portions of content of the Database ('Materials'), primarily for your own use, according to the terms of this Agreement. This license includes:

(a) The right to electronically display Materials retrieved from the Database on your computer terminal;

(b) The right to download Materials by means of the download commands of the HeinOnline website and to store a single copy of Materials in a machine-readable form on your computer; and

(c) The right to print Materials by means of the printing commands of the HeinOnline website and to create a single print of Materials downloaded by means of the downloading commands of the HeinOnline website.

Except as specifically provided above, you are prohibited from downloading, storing, reproducing,transmitting, displaying, copying, distributing, or using any portion of the Database. Without limiting the preceding sentence, you shall not download or print an entire issue or issues of a publication or journal within the Database. You may contact HeinOnline by telephone or in writing in order to obtain a printed copy of one or more entire issues of such a publication or journal subject to payment of any applicable charge.

Other terms apply to this subscription. See the complete license at heinonline.org. 


\title{
Facial Challenges to State and Federal Statutes
}

\author{
Michael C. Dorf*
}

Courts can hold a statute unconstitutional either on its face or as-applied, and the standards courts use significantly affect the likelihood of a successful constitutional challenge. In this article, Professor Dorf analyzes the Supreme Court's facial challenge doctrine, which purports to restrict facial challenges to those cases in which a statute can be constitutionally applied in "no set of circumstances." Professor Dorf argues first that all persons have a right to be judged by a valid rule of law, and that the Court's current facial challenge doctrine can only be squared with this right if the Court is employing a presumption of severability-that unconstitutional aspects of a statute can be severed from constitutional ones by a process of judicial interpretation. Professor Dorf then discusses the limits imposed on this presumption of severability by both substantive constitutional law and institutional concerns. In analyzing the former, he argues that the First Amendment overbreadth doctrine, which the Court has recognized limits the applicability of the "no set of circumstances" test, should be and in fact has been applied outside the First Amendment context in a manner inconsistent with the facial challenge rule. He also argues that the facial challenge rule is inconsistent with principles of federalism, as it prevents federal courts from giving proper deference to state courts on issues of state law. Professor Dorf concludes that the Court's "no set of circumstances" test does not accurately refiect the Court's facial challenge doctrine, and recommends that the Court eschew categorizing constitutional challenges as either facial or as-applied, focusing instead on the underlying substantive and institutional issues.

INTRODUCTION ...................................... 236

I. The Salerno Principle, Severabiltty, and the Rule of LaW . 239

A. The Salerno Principle .......................... 239

B. The Right to Be Judged by a Constitutionally Valid Law ..... 242

1. Evidentiary considerations ...................... 244

2. A privileged-conduct-only rule .................. 244

3. Marbury v. Madison and the right to be judged by $a$ constitutionally valid rule of law.....................

* Assistant Professor of Law, Rutgers University (Camden). A.B., 1986, J.D., 1990, Harvard University. Sherry Colb, Russell Coonibs, Perry Dane, Jonathan Mallamud, Earl Maltz, Henry Monaghan, Allan Stein, and Laurence Tribe provided helpful comments and suggestions. Dean Roger Dennis furmished financial support. John Caldwell, Jeanne King, and Stuart Rudoler contributed tireless research assistance. 
4. The Supremacy Clause and the Constitution ........... 248

C. Severability Doctrine ............................ 249

II. Constitutional Barriers to the YazoO/SalerNo Presumption of SEVERABILITY . . . . . . . . . 251

A. Underinclusive Statutes and the Equal Protection Clause..... 251

1. Contrasting Orr v. Orr with the Salerno presumption ..... 253

2. R.A.V. and the underinclusive/overinclusive distinction ... 257

B. Overbreadth Doctrine and the Salerno Principle ........... 261

1. The special standing component to First Amendment overbreadth doctrine .............................. 261

2. Overbreadth doctrine and fundamental rights .......... 264

3. The scope of overbreadth doctrine ................. 268

4. The Court's privacy jurisprudence and the Salerno principle ................................... 271

5. The basis of overbreadth doctrine ................. 277

C. Impermissible Purpose and the Salerno Principle .......... 279

D. Concluding Remarks on Constitutional Barriers to the Salerno Presumption of Severability ....................... 281

III. Institutional Limits to the Presumption of SeVerability .... 283

A. Facial Challenges to State Statutes .................... 283

B. Facial Challenges to Federal Statutes................. 288

Conclusion ............................................. 294

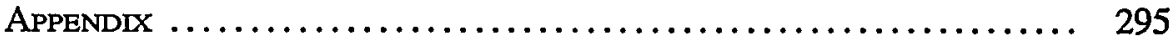

\section{INTRODUCTION}

Conventional wisdom holds that a court may declare a statute unconstitutional in one of two manners: (1) the court may declare it invalid on its face, or (2) the court may find the statute unconstitutional as applied to a particular set of circumstances. The difference is important. If a court holds a statute unconstitutional on its face, the state may not enforce it under any circumstances, unless an appropriate court narrows its application; in contrast, when a court holds a statute unconstitutional as applied to particular facts, the state may enforce the statute in different circumstances.

In recent years, the Supreme Court has purported to disfavor facial challenges. As the Court stated in United States v. Salerno, " "[a] facial challenge to a legislative Act is, of course, the most difficult challenge to mount successfully, since the challenger must establish that no set of circumstances exists under which the Act would be valid."2 However, as I illustrate with numerous cases decided both before and after Salerno, the Court has failed to apply this test. This discrepancy suggests that the Salerno "no set of circumstances" principle does not accurately characterize the standard for deciding facial challenges.

Justice Scalia's recent dissent from the denial of certiorari in Ada v. Guam

1. 481 U.S. 739 (1987) (holding that the Bail Reform Act of 1984 is not facially invalid).

2. Id. at 745 . 
Society of Obstetricians and Gynecologists ${ }^{3}$ demonstrates the significance of whether the Court uses the Salerno test. In Ada, the United States Court of Appeals for the Ninth Circuit rehed on Roe v. Wade 4 to invalidate a Guam law that prohibited all abortions except when two independent doctors confirm that the pregnancy would endanger the woman's life or seriously impair her health. ${ }^{5}$ After this ruling, the Supreme Court decided Planned Parenthood v. Casey, ${ }^{6}$ in which it reaffirmed "the essential holding of Roe v. Wade," including "the right of the woman to choose to have an abortion before viability and to obtain it without undue interference from the State."7 In denymg certiorari in Ada, the Court signaled the obvious: The Guam law was inconsistent with Roe and Casey and therefore unconstitutional. Yet Justice Scalia, joined by Chief Justice Rehnquist and Justice White, dissented, arguing that because the Guam statute could be constitutionally applied in some circuinstances, such as to postviability abortions, the court should have upheld the statute against a facial challenge under Salerno. ${ }^{8}$

Two Justices have expressly disagreed with Justice Scalia's approach in $A d a$, arguing that, at least as applied to abortion regulations, the Court's standard is one that invalidates laws deemed unconstitutional "in a large fraction of the cases," not necessarily in every case. ${ }^{9}$ In contrast, if courts were to measure a statute's facial validity by asking whether it can be constitutionally applied to anyone, as Salerno requires, they would have to find a statute facially valid that includes within its ambit any proscribable conduct, such as some third trimester

3. 113 S. Ct. 633 (1992) (Scalia, J., dissenting).

4. 410 U.S. 113 (1973).

5. Guam Soc'y of Obstetricians \& Gynecologists v. Ada, 962 F.2d 1366, 1368 n.1 (9th Cir.), cert. denied, 113 S. Ct. 633 (1992).

6. 112 S. Ct. 2791 (1992).

7. Id. at 2804.

8. Ada, 113 S. Ct. at 633-34 (Scalia, J., joined by Rehnquist, C.J., and White, J., dissenting). The three Ada dissenters had opposed the reaffirmance of Roe in Casey; their views about facial challenges may have been colored by their belief that those cases were wrongly decided. In fact, Justice Scalia avoided using the term "viability," referring instead to "abortions conducted after the point at which the child may live outside the womb." Id. at 634. Justice Thomas was the only Casey dissenter who did not join the Ada dissent. His failure to do so may not indicate his true beliefs, for had he voted with the Chief Justice and Justices White and Scalia, he would have becn the fourth vote necessary to grant certiorari. Justice Thomas may have recognized that granting certiorari would likely have resulted in an affirmance of the Ninth Circuit's ruling by the same 5-4 margin that decided Casey. (Ada came before the Court before Justice White announced his intention to retire at the end of the October 1992 Term). Hence, Justice Thomas' refusal to join the Ada dissent should not necessarily be read as a sign of disagreement with it.

9. Fargo Women's Health Org. v. Schafer, 113 S. Ct. 1668, 1668-69 (1993) (O'Connor, J., joined by Souter, J., concurring). In Fargo, the Court refused to issue a stay pending appeal of a district court ruling that upheld North Dakota's 24-hour waiting period for abortions. The district court had applied the reasoning of Justice Scalia's Ada dissent, holding that the plaintiffs "could not mount a successful facial challenge because they were unable to show 'that no set of circumstances exists under which the [challenged] provisions would be valid." II. at 1668 (quoting Solerno, 481 U.S. at 745). While Justices O'Connor and Souter ultimately agreed with the district court's judgment that a stay was not warranted, they emphasized that the district court's reliance on the Ada dissent was misplaced because the petitioners in Casey had not becn required "to show that the [spousal notification] provision would be invalid in all circumstances." Id. at 1669 . Instead, a law restricting abortions "is invalid, if, "in a large fraction of the cases in which [the law] is relevant, it will operate as a substantial obstacle to a woman's choice." Id. (quoting Casey, $112 \mathrm{~S}$. Ct. at 2830 (alterations in the original)). 
abortions. In short, Justice Scalia's application of the Salerno principle to Guam's abortion law is sound. If there is a flaw in his argument, it lies with Salerno itself.

This article argues that the Salerno principle is wrong. It neither accurately reflects the Court's practice with respect to facial challenges, nor is it consistent with a wide array of legal principles. The proper disposition of a facial challenge is intimately bound up in questions of substantive constitutional law, institutional competence, and statutory interpretation.

Throughout this article, I attempt to clarify facial challenge doctrine and its applications. ${ }^{10}$ Part I sets forth the theoretical underpinnings of the doctrine. In brief, if a litigant can show that a statute would be unconstitutional as applied to her, the court will declare the statute void as applied to that litigant. ${ }^{11}$ This deceptively simple principle does not mean, however, that a statute is unconstitutional "as applied" only if the litigant challenging the statute has a constitutional right to engage in the conduct that the statute prohibits or circumscribes. Rather, because no one may be judged by an unconstitutional rule of law, 12 a statute that has unconstitutional applications cannot be constitutionally applied to anyone, even to those whose conduct is not constitutionally privileged, unless the court can sever the unconstitutional applications of the statute from the constitutionally permitted ones. Part I concludes that the Salerno principle effectively establishes an irrebuttable presumption that a statute's unconstitutional applications are severable from its constitutional ones.

Generally, severability is a question of statutory interpretation, not constitutional law. ${ }^{13}$ I argue in Part II, however, that certain constitutional doctrines, including (1) the Equal Protection Clause and structurally similar constitutional prohibitions on discriminatory treatment, (2) the concern that some overbroad statutes will "chill" the exercise of First Amendment and other fundamental rights, and (3) various constitutional doctrines that use legislative purpose to

10. As commentators have been aware for a considerable period, the Court's treatment of facial challenges often appears contradictory. See, e.g., Robert P. Gorman, Note, Judging the Statute in the Light of the Acts of the Defendant, 31 Notre Dame LAw. 689, 689 (1956). Gorman notes that the Court sometimes examines whether a law is invalid on its face, as in Lanzetta v. New Jersey, 306 U.S. 451, 453 (1939), and Lovell v. City of Griffin, 303 U.S. 444, 451 (1938). In other cases, however, the Court examines the constitutionality of the law based on whether the law is invalid as apphed to the particular plaintiff in light of the facts presented, as in Kunz v. New York, 340 U.S. 290,304 (1951) (Jackson, J., dissenting), and Yazoo \& Mississippi Valley R.R. v. Jackson Vinegar Co., 226 U.S. 217, 219-20 (1912). Gorman addresses the contradiction by hypothesizing that the Court gives a "preferred position" to "personal liberty cases"- and strikes down statutes that endanger those liberties. Gorman, supra, at 694-96. 1 believe this "preferred position" to be roughly synonymous with the Court's current overbreadth doctrine. See text accompanying notes 95-181 infra. Gorman notes, however, that First Amendment cases seem to be the only area in which the Court is generally consistent. Gorman, supra, at 698 .

11. See Gerald Gunther, Constitumional Law 1192 (12th ed. 1991) (noting that the typical "as applied" challenge is brought by a person whose acts are protected under the Constitution).

12. I argue below that this principle is a necessary element of the American practice of judicial review. See notes 32-54 infra and accompanying text.

13. See, e.g., Dorchy v. Kansas, 264 U.S. 286, 289-91 (1924) (stating that an unobjectionable provision can be considered severable from an invalid provision only if, standing alone, the unobjeetionable provision can have legal effect, and the legislature intended the provision to stand even if others were invalid). 
determine a statute's validity, are inconsistent with a practice of severing invalid applications of a statute. The Supreme Court's treatment of facial challenges in these three areas does not reflect a commitment to the Salerno test. Not only does the Court inconsistently apply the broad Salerno principle, it fails to articulate why it departs from Salerno or to justify the extent of its departure. This article attempts to do both.

Part III considers how principles of federalism affect the resolution of facial challenges. Because a statute's facial validity ultiunately turns on statutory construction, the appropriate resolution of cases involving federal and state statutes may differ. I argue that the Court's use of the same standard for facial challenges to all state statutes conflicts with its usual approach to questions of state law in which federal courts accommodate state-by-state variations. Part III also addresses the question of how a federal court should treat a facial challenge to a federal statute.

At the end of the article, I conclude that contrary to what Salerno proclaims, no single legal standard controls the judginent of facial challenges in practice. Reliance on ultimately superficial distinctions between facial and asapplied challenges to statutes only confuses the underlying concerns of substantive constitutional doctrine and institutional competence that govern the resolution of each case.

\section{The Salerno Principle, Severabitity, and the Rule of LaW}

\section{A. The Salerno Principle}

Chief Justice Rehnquist's opinion in Salerno announces that a facial challenge to a statute will fail if the statute has any constitutional application. ${ }^{14}$ If Salerno really set forth the governing standard, however, litigants would rarely bring facial challenges. In an as-applied challenge, if the statute in question cannot be constitutionally applied to the litigant, then she will prevail without having to show that no set of circumstances exists under which the statute could be constitutionally applied to soneone else. On the other hand, if the litigant loses her as-applied challenge, she will also lose her facial challenge under Salerno because the statute is constitutional in at least one circumstance. In short, a litigant can prevail on a facial challenge only if she can also prevail on an as-applied challenge, and even then she may lose the facial challenge. Under Salerno, a litigant bringing a facial rather than an as-applied challenge gams nothing.

Moreover, the Salerno opinion cites no direct authority to support its truly draconian standard. ${ }^{15}$ The Court's justification appears in the sentence follow-

14. United States v. Salemo, 481 U.S. 739, 745 (1987).

15. Although not cited in Salerno, Keyishian v. Board of Regents, 385 U.S. 589 (1967), could be said to support the "no set of circumstances" test. In Keyishian, the Court characterized an earher decision upholding two statutes against a facial challenge as merely holding that those laws "were capable of constitutional application." Id. at 594. That characterization may, however, have reflected the Court's understanding of the proper himits of jurisdiction in a suit for declaratory relief from anticipated harm. 
ing the announceinent of the test: "The fact that the [statute] might operate unconstitutionally under soine conceivable set of circumstances is insufficient to render it wholly invalid ...."16

The Salerno Court thus directs its argument at a straw nnan. While a statute that "might operate unconstitutionally under soune conceivable set of circumstances" could be facially valid, it hardly follows, as the Court implies, that a statute with a large number of obviously unconstitutional applications slould be facially valid merely because there exists some set of circumstances, no matter how small or insigmificant, under which the statute can be applied without violating a constitutional guarantee. A wide gulf separates the statute that might operate unconstitutionally under some conceivable set of circumstances froin one that operates unconstitutionally under all circumstances. The Court im Salerno does not explain why its rejection of the very low threshold necessitates adoption of the very high one. Yet this leap affects a broad imddle range of statutes, which are unconstitutional in a substantial number of applications but constitutional in a substantial number of others. Under Salerno, courts unust hold this broad middle range of statutes facially valid simply because statutes in a different category - those that potentially have unconstitutional applications in a very limited set of circunstances-are also facially valid.

Even if the "no set of circumstances" test had been the result of a carefully reasoned analysis, Salerno was a peculiar case in which to announce the standard because the Court never applied the test in reaching its decision. In Salerno, respondents challenged the constitutionality of the Bail Reform Act of 1984, which authorizes a federal court to detain an indictee without bail pending trial upon a showing by clear and convincing evidence that "no release conditions "will reasonably assure ... the safety of any other person and the community." 17 The respondents argued that the Act is facially invalid under the Due Process Clause of the Fifth Amendment and the Excessive Bail Clause of the Eighth Amendunent. Because the state cannot confine a person not accused of a crime inerely upon a showing of future dangerousness, the respondents argued, and Justice Marshall echoed in his dissent, to treat indictees differently would give evidentiary weight to the indictment and thereby undercut the presunption of innocence. ${ }^{18}$ The Court disagreed, rejecting the respondents' substantive and procedural due process challenges as well as their Eighth Amendment challenge. ${ }^{19}$

Putting aside the merits of the case, ${ }^{20}$ one finds no apparent link between

16. Salerno, 481 U.S. at 745.

17. Id. at 741 (quoting the Bail Reform Act of 1984) (alteration in original).

18. Id. at 762-66 (Marshall, J., dissenting).

19. Id. at 755 .

20. As one might expect, commentators have given the result in Salerno mixed reviews. Compare Michael W. Youtt, Note, The Effect of Salerno v. United States on the Use of State Preventive Detention Legislation: A New Definition of Due Process, 22 GA. L. REv. 805 (1988) (noting that Salerno's extensive procedural safeguards will both protect the accused and allow the government interest in limiting postarrest crime) and Alexia J. Johnston, Note, United States v. Salerno: Preventive Detention-Coming of Age, 1988 DET. C.L. REv. 135 (arguing that Salerno was a positive step toward protecting society from criminals) with Michael J. Eason, Note, Eighth Amendment-Pretrial Detention: What Will Become of the Innocent?, 78 J. CRIM. L. \& CRIMINology 1048 (1988) (arguing that, at soine point, ex- 
the Court's opening broadside decrying the facial challenge vehicle and the actual decision. At best, the Court throws in a rhetorical flourish to reassure the reader: Because the suit is, after all, a facial challenge, the reader need not worry that what is being upheld appears constitutionally questionable.

Under the "no set of circumstances" test, the government need only produce an example in which the statute could be applied constitutionally to defeat the facial challenge. Sucl an example is readily available in the Salerno context. Since well established law allows a judge to set bail at an amount appropriate to deter flight, ${ }^{21}$ in cases where defendants would flee regardless of how high bail is set-such as defendants facing long sentences or capital punishment if convicted-a judge may deny bail altogether without running afoul of either the Due Process Clause or the Eighth Amendment. Thus, the Bail Reform Act can be constitutionally applied to defendants who are flight risks, regardless of whether future dangerousness is a generally invalid criterion. Because the application of the statute to defendants who pose a flight risk is constitutional, the respondents fail to carry their burden of showing that there exists "no set of circumstances" under which the Act can be constitutionally applied.

The Court's opinion does not, however, proceed along these lines. Instead, the Court attempts to establish future dangerousness as a legitimate basis for detaining any indictee pending trial. ${ }^{22}$ The Court niakes all the arguments necessary for the denial of an as-apphied challenge, first qualifying the nature of the detainee's interest in liberty, and then extolling the government's interest in protecting citizens against violence. Despite the Court's obligatory disclaimer that it expresses no view on the likely success of an as-applied challenge, ${ }^{23}$ such success is difficult to imagine in light of the Court's validation of the Bail Reform Act's central criterion for confinement.

Perhaps the Court's disclaimer means only that the Act, while facially valid, might still be unconstitutionally applied if a court happens to violate a

tended pretrial detention becomes punitive and unconstitutional) and John B. Howard, Jr., Note, The Trial of Pretrial Dangerousness: Preventive Detention After United States v. Salerno, 75 VA. L. REv. 639 (1989) (questioning whether Salerno will encourage lower courts to deny bail without adequately focusing on the specific threat posed by the defendant if released before trial).

21. See, e.g., Stack v. Boyle, 342 U.S. 1, 5 (1951).

22. Salemo, 481 U.S. at $747-48,751$. One portion of the Court's opinion in Salemo appears to apply the "no set of circumstances" test by pointing to a possible constitutional application. The Court states that "[t]o sustain [the procedures of the Act] against [a facial] challenge, we need only find thein 'adequate to authorize the pretrial detention of at least some [indictees].'" Id. at 751 (quoting Schall v. Martin, 467 U.S. 253, 264 (1984)). Careful scrutiny of the authority cited, however, reveals that the Court's reliance on the language in Schall is misplaced. The language in Schall precedes citations of Mathews v. Eldridge, 424 U.S. 319, 335 (1976), and Gerstein v. Pugh, 420 U.S. 103, 114 (1975), both of which involved claims that a procedural schente was inconsistent with the requirements of due process; in each case the Court used a balancing test to weigh the relative interests of the government and the suspect. In neither case did the Court hold a set of procedures constitutional by showing that they could legitimately authorize some deprivations of liberty. And indeed, although the Schall Court used the "at least some" language, it actually applied a balancing approach like Mathews and Gerstein. See Schall, 467 U.S. at 274-77. Thus, when the Court in Salemo upholds the procedures of the Bail Reform Act because "the protections are more exacting than those we found sufficient" in Schall, Salemo, 481 U.S. at 752, it implicitly applies the same balancing test instead of applying the "no set of circumstances" standard to the specific situation in Salemo.

23. See Salemo, 481 U.S. at 745 n.3. 
constitutional norm while complying with the language of the Act. If, for example, a judge were to find an indictee dangerous based in part on her race, the finding would present an unconstitutional "apphication" of the Bail Reform Act. But such an application would be unconstitutional because of the nature of the judge's action, rather than anything in the statute, and we would more naturally classify the judge's action as a straightforward equal protection violation. If this is the only kind of as-applied challenge that remains open after Salerno, then the Court has gone beyond what the "no set of circumstances" test requires. The Court does not simply deem the Bail Reform Act capable of constitutional application; it declares the Act virtually incapable of unconstitutional application. Hence, Salerno iromically fails to adhere to the "no set of circumstances" standard it announces.

Of course, this criticism of Salerno does not, in itself, deinonstrate that the "no set of circumstances" test is wrong. The Court's failure to justify the test does not mean that no justification exists. Salerno may have simply been an easy case in which the facial challenge would have failed even if the Court had applied a less demanding standard. Can we justify the Salerno standard when a case's outcome depends on the standard? My evaluation of this question hinges on whether individuals have a right to be judged by a constitutionally valid rule of law. If such a right exists, as I demonstrate in the next Part, the Salerno principle requires that a statute's unconstitutional applications be severable from its constitutional ones. I explore the implications of this conclusion in Parts II and III.

\section{B. The Right to Be Judged by a Constitutionally Valid Law}

The logic behind the Salerno principle contradicts the principle that Henry Monaghan has articulated: "[A] litigant has always had the right to be judged in accordance with a constitutionally valid rule of law." 24 An early precursor of Salerno illustrates this contradiction.

In 1912, the Court in Yazoo \& Mississippi Valley R.R. v. Jackson Vinegar Co. ${ }^{25}$ rejected a facial challenge to a statute because that statute had some constitutional applications. In that case, the Yazoo Railroad challenged a Mississippi statute that required railroads to settle all claims for lost or damaged goods promptly. The Railroad argued that the statute should be held invalid because it would apply even when claims were fraudulent or frivolous. ${ }^{26}$ The particular claim at issue, however, was neither fraudulent nor frivolous, and the Court refused to consider the Railroad's facial challenge, treating it entirely as an as-applied challenge. ${ }^{27}$ As the Court put it: "It suffices ... to hold that, as

24. Henry Paul Monaghan, Overbreadth, 1981 Sur. CT. Rev. 1, 3. Monaghan, aware of this tension, constructs his approach to overbreadth as a means of addressing it. See id. at 4-14.

25. 226 U.S. 217 (1912).

26. Id. at 219.

27. See also United States v. Raines, 362 U.S. 17, 21 (1960) ("[O]ne to whom application of a statute is constitutional will not be heard to attack the statute on the ground that ... applying [it] to other persons or other situations ... might be unconstitutional."); Missouri Rate Cases, 230 U.S. 474, 508-09 (1913) ("The acts are valid upon their face as a proper exercise of governmental authority in the establishment of reasonable rates, and each complainant in order to succeed in assailing thein must show 
applied to cases like the present, the statute is valid."28

Although not inherently contradictory, the result in Yazoo does seem contrary to the right to be judged by a valid rule of law. If the statute requiring railroads to settle all claims promptly is an unconstitutional exercise of the state's authority, then, one would suppose, no railroad should be judged by it, even if the railroad's conduct merits no constitutional protection.

Monaghan attempts to demonstrate this point by asking us to assume that people have a constitutional right to dance in a barroom unless the dancer is barefoot. Suppose a state statute prohibits all barroom dancing, regardless of whether the dancer wears shoes. According to Monaghan, convicting even a barefoot dancer under the statute is clearly unconstitutional, although he fails to explain why. ${ }^{29}$ In similarly conclusory fashion, Richard H. Fallon, Jr., asserts that " $[t]$ he due process clause or, more generally, the rule of law" entitles litigants to challenge laws that are "unconstitutional as applied to someone else."30

While I agree with Monaghan and Fallon that the United States Constitution permits only the application of constitutional rules, this conclusion is by no means self-evident. ${ }^{31}$ Examining possible justifications for this entitlement

that as to it the rates are confiscatory."); Smiley v. Kansas, 196 U.S. 447, 454-55 (1905) (accepting the state supreme court's holding that the statute constitutionally proscribed the defendant's conduct, irrespective of whether the statute's language could also be construed to proscribe conduct beyond the state's control).

28. Yazoo, 226 U.S. at $219-20$.

29. See Monaghan, supra note 24, at 910 . The apparent source for Monaghan's hypothetical is Thompson v. City of Louisville, 362 U.S. 199 (1960). See Monaghan, supra note 24, at 9 n.33. As I argue below, see text accompanying notes 46-54 infra, Monaghan correctly concludes that a litigant has a right not to be judged by an unconstitutional rule of law, although Thompson itself fails to provide support for that conclusion. In Thompson, the Court did not actually invalidate the ordinance. Rather, the Court held that the conviction violated due process because there was no evidence of the defendant's guilt. Thompson, 362 U.S. at 206.

30. See Richard H. Fallon, Jr., Making Sense of Overbreadth, 100 YALE L.J. 853, 862 (1991); see also LaURence H. Tribe, American Constrturtional Law \$ 1227, at 1023-24 (2d ed. 1988); Note, The First Amendment Overbreadth Doctrine, 83 HARv. L. REv. 844, 848 (1970) (stating that an overbreadth claim is not "ineluctably vicarious" because the claimant "is asserting his own right not to be burdened by an unconstitutional rule of law").

31. Monaghan's barrooin dancing example poses but fails to answer the question whether there is a right to be judged by a valid rule of law. In a more recent article, he gives a more realistic but no less conclusory example. Beginning from the premise that a statute prohibiting "whistling in any building" would be unconstitutional because irrational, he contends that such a statute could not be applied even to one who disrupts a judicial proceeding by whistling in a courtrooin. Henry P. Monaghan, Harmless Error and the Valid Rule Requirement, 1989 SUP. CT. REv. 195, 196.

Likewise, none of the cases Monaghan cites stands for the proposition that there is a right to be judged by a valid rule. See Monaghan, supra note 24, at 9 n.34. Two of the cases he cites focus on the evidentiary concerns that arise when a statute prohibits both constitutionally protected and unprotected conduct. See Bachellar v. Maryland, 397 U.S. 564, 569-71 (1970) (overturning the conviction of demonstrators against the Vietnam War because there was no way of knowing whether the jury based its decision on constitutional or unconstitutional grounds); Williams v. North Carolina, 317 U.S. 287, 292 (1942) (overturning a bigamy conviction because the jnry could have decided on the basis of either of two laws, only one of which was constitutional). Similar reasoning explains the holding in Ulster County Court v. Allen, 442 U.S. 140, 159-60 (1979), that, when a defendant challenges the use of a mandatory presumption, the sufficiency of the evidence is irrelevant, as a mandatory presumption is unconstitutional precisely because it may lead a jury to iguore the evidence. As I note in the text 
provides a better understanding of its consequences in the context of a facial challenge.

\section{Evidentiary considerations.}

In inany Supreine Court cases, the evidence considered at trial requires the Court to judge a statute on its face rather than as applied. Consider again Monaghan's barroom dancing example. If the statute prohibits all barrooin dancing, a jury could find that a dancer violated the statute without making a factual determination as to whether the dancer was barefoot. Assuming a constitutional right to dance in a barrooin, however, an appellate court cannot sustain such a conviction under the statute because there is no jury finding on this crucial question. ${ }^{32}$ Furthermore, in both criminal and civil cases, courts cannot sustain verdicts that inay rest on constitutionally inpermissible grounds.

These evidentiary considerations partially establish the right to be judged by a constitutionally valid law, but do not entirely justify the right. Suppose a jury returned a special verdict inaking clear that the barrooin dancer was barefoot. Is it still impermissible to judge her under a law that is unconstitutional in other respects? Perhaps it is, but not because of evidentiary considerations. Before examining additional factors supporting a right to be judged by a constitutionally valid rule of law, it is helpful to consider the ramifications of an opposite rule.

\section{A privileged-conduct-only rule.}

Inagine a democratic and rights-respecting polity that allows litigants to challenge the constitutionality of a statute only if it burdens their own constitutionally protected conduct-what I shall refer to as a "privileged-conduct-only

accompanying note 32 infra, these concerns, although important, do not entirely establish a right to be judged by a valid mle of law.

Another of the cases Monaghan cites, Montana Co. v. St. Louis Mining \& Milling Co., 152 U.S. $160,169-70$ (1894), involves a violation of what we would now call procedural due process. But a party who contends that a procedure is so unfair as to deny due process does not need to demonstrate a constitutional right to the underlying entitlement or privilege. See, e.g., Goldberg v. Kelly, 397 U.S. 254, 262-63 (1970) (holding that public assistance payments cannot be terminated without a hearing, even though the benefits are not a constitutional right).

In the remaining cases Monaghan cites, the Court grants relief to a party whose own conduct is not constitutionally privileged because, as a matter of statutory construction, it finds that the invalid applications of the statute are not severable from the valid ones. See New York Cent. R.R. v. White, 243 U.S. 188,197 (1917) (noting that had a worker's compensation scheme been invalid as applied to employees, it could not have been applied to employers either); Illinois Cent. R.R. v. McKendree, 203 U.S. 514, 528-30 (1906) (holding that the Secretary of Agriculture cannot draw a quarantine line that regulates not only interstate but also intrastate commerce); United States v. Ju Toy, 198 U.S. 253, 262 (1905) (stating that a statute "must be valid as to all that it embraces, or altogether void. An exception of a class of constitutionally exempted cannot be read into those general words merely for the purpose of saving what remains"); Trade-Mark Cases, 100 U.S. 82, 98-99 (I879) (invalidating a statute regulating the use of trademarks because it was beyond the authority of Congress). As I argue throughout this article, severability considerations are critical to understanding facial challenges, but they involve statutory questions; they do not establish a constitutional right to be judged by a valid rule of law. law.

In sum, Monaghan offers no argument or authority for a general right to be judged by a valid rule of

32. Bachellar, 397 U.S. at 569-71; Williams, 317 U.S. at 292. 
rule." The polity might view such a rule as a kind of standing requirement, analogous to the requirements litigants claiming rights under a treaty or the Fourth Amendment must meet.

Generally, a court will not hold that a treaty between nations confers rights enforceable by mdividual citizens absent a clear manifestation of the signatories' intent to do so. ${ }^{33}$ Instead, courts presume that a treaty creates rights and obligations enforceable only between the signatory nations, and individuals lack the third-party or derivative standing to assert the treaty rights. ${ }^{34}$ Whether right or wrong, ${ }^{35}$ limiting the justiciability of treaty provisions presumably serves a separation of powers objective. Because treaties are primarily the domain of the political branches, especially the Executive, courts will enforce a treaty only when the treaty's own terms require them to do so.

The Supreme Court has likewise restricted Fourth Amendinent standing, holding that a criminal defendant may not exclude illegally obtained evidence from her trial unless the illegal search or seizure violated her own Fourth Amendment rights. ${ }^{36}$ Because the Court considers Fourth Amendment rights "personal rights," third parties cannot assert them. ${ }^{37}$

One could defend a privileged-conduct-only rule for statutes as structurally identical to the standing requirements for litigants claiming Fourth Amendment or treaty rights. The courts may not punish an illegal search of A by suppressing illegally obtained evidence at the trial of B. Nor may the courts enforce a treaty provision designed to benefit nation $C$ by permitting individual $D$ to raise it in litigation that does not involve $C$. So, one might argue, the courts may not invalidate a statute which infringes $E$ 's constitutional rights by refusing to apply it to $\mathrm{F}$.

A privileged-conduct-only rule restricting constitutional challenges to cases that implicate the litigant's own personal rights serves two institutional purposes. ${ }^{38}$ First, as with treaties, it reduces the room for judicial interference with the other branches of government. Of course, any restriction on judicial power

33. See, e.g., Frolova v. U.S.S.R., 761 F.2d 370, 373-76 (7th Cir. 1985) (holding that individuals cannot enforce rights under the United Nations Charter).

34. See, e.g., United States v. Alvarez-Machain, 112 S. Ct. 2188, 2195 (1992) (noting that an individual's rights under a United States-Mexico treaty are derivative of her nation's rights).

35. Although not illogical, the Court's approach to treaty interpretation seems inconsistent with the literal text of the Supremacy Clause ("[A]ll Treaties nuade ... under the Authority of the United States, shall be the supreme Law of the Land."). U.S. ConsT. art. VI, cl. 2. See Carlos Manuel Vázquez, Treaty-Based Rights and Remedies of Individuals, 92 CoLum. L. Rev. 1082 (1992) (arguing that the Framers declared treaties to be the suprenie law of the land so that individuals would have the power to enforce their provisions in donestic courts).

36. See, e.g., Rakas v. Illinois, 439 U.S. 128 (1978) (refusing to allow defendants to exclude illegally obtained evidence because the search had not violated the defendants' own rights).

37. Id. at 133-34 ("Fourth Amendment rights are personal rights which ... may not be vicariously asserted." () (quoting Alderman v. United States, 394 U.S. 165, 174 (1969)). Admittedly, suppressing evidence obtained in violation of the Fourth Amendinent serves a deterrent function regardless of whose rights the search or seizure violated. But the exclusionary rule also carries the costs of underenforcement of criminal laws. Accordingly, the Court's limitations on Fourth Amendment standing inay represent a determination that these costs outweigh the benefits of a broader definition of justiciability.

38. For a similar analysis of the justifications underlying justiciability doctrine, sec Lea Brilnuayer, The Jurisprudence of Article III: Perspectives on the "Case or Controversy" Requirement, 93 HaRv. L. Rev. 297, 302-06 (1979). 
has this effect. But the argument for judicial restraint has greatest force when allowing the other branches free rein is unlikely to result in a diminution of individual liberty. And, by hypothesis, no decrease in individual liberty results when a litigant concedes that her own behavior is not constitutionally privileged.

Second, the privileged-conduct-only principle confines judicial decisionmaking to real, as opposed to hypothetical, cases. Assuming that courts function best when presented with concrete rather than abstract controversies, the principle reduces the risk of erroneous decisions. I shall refer to these two points in favor of a privileged-conduct-only rule as the interest in legislative supremacy and the interest in concrete decisionmaking, respectively.

\section{Marbury v. Madison and the right to be judged by a constitutionally valid rule of law.}

While the interests in legislative supremacy and concrete decisionmaking merit consideration, requiring a litigant to establish that her conduct is constitutionally privileged before allowing her to challenge a statute fundamentally conflicts with the theory of judicial review underlying Marbury v. Madison. ${ }^{39}$

Consider first the principle of legislative supremacy. The substantive question Marbury addresses-whether Congress may expand the original jurisdiction of the Supreme Court beyond the categories enumerated in Article IIImight be termed a structural question of constitutional law. The provision does not directly bear on individual rights. Indeed, the party invoking the Constitution did not even claim an individual right. Only William Marbury, who asserted a right to his commission as a justice of the peace, made an individual claim. Yet the Court permitted Madison to invoke the Constitution to defeat Marbury's admittedly valid, albeit subconstitutional, claim. ${ }^{40}$

One could argue that, although Madison invoked no individual right, ${ }^{41}$ the ultimate purpose of the Constitution's structural provisions is the preservation of individual liberty. ${ }^{42}$ While this argument has great force, it hardly supports a rule requiring every litigant to demonstrate a threat to her own constitutional rights. Structural provisions may, in the long run, preserve individual liberty, but they do not inevitably do so in every case. As in Marbury, a litigant could

39. 5 U.S. (1 Cranch) 137 (1803). For an argument that Marbury is inconsistent with as-applied challenges, see Note, supra note 30 , at 850-51. By implication, the same is true of clallenges to state laws. See, e.g., Martin v. Hunter's Lessee, 14 U.S. (1 Wheat.) 304 (1816); Fletcher v. Peck, 10 U.S. (6 Cranch) 87 (1810).

40. For the canonical critique of Marbury, see William W. Van Alstyne, A Critical Guide to Marbury v. Madison, 1969 Duke L.J. 1. 1 use the term "subconstitutional" to describe rules of law that are not required by the Constitution.

41. As a representative of the federal government, Madison, in some sense, invoked the "individual" rights of the government. I am using the term "individual rights" to refer to privileges of individual natural persons to engage in various courses of conduct, but this may be somewhat inconsistent with the term's use in Marbury. When, for example, the Court explains that its role is "to decide on the rights of individuals," Marbury, 5 U.S. at 170, it employs the phrase to indicate the interests of particular litigants, as opposed to inore general matters.

42. See Youngstown Sheet \& Tube Co. v. Sawyer, 343 U.S. 579, 635 (1952) (Jackson, J., concurring) ("[T]he Constitution diffuses power the better to secure liberty . ..."). 
claim a right to a writ of mandamus in order to force a government official to stop violating his rights. Alternatively, a litigant could sue for a writ of mandamus to compel a government official to take a course of action that infringes someone else's liberty. Therefore, a judgment that Article III's exhaustiveness regarding the Supreme Court's original jurisdiction is justiciable cannot rest solely on the assumption that a contrary decision would result in a diminution of individual liberty.

Perhaps the second putative justification for the privileged-conduct-only rule, the interest in concrete decisionmaking, offers a more compelling reason. No doubt this interest is important; in fact, Article III requires an actual case or controversy as a prerequisite to adjudication in the federal courts. But does the interest in concrete decisionmaking justify something more? To return to Monaghan's example, when a criminal defendant challenges the prohibition on all barroom dancing, she presents a real issue in terms of the Article III limits on justiciability. The statute's validity determines whether she goes to prison. ${ }^{43}$ Thus, the interest in concrete decisionmaking supports a privilegedconduct-only rule, but solely as a prudential or subconstitutional matter.

Prudential considerations cannot, of course, trump constitutional ones. ${ }^{44}$ To the extent that the prudential arguments for a privileged-conduct-only rule conflict with constitutional principles, the former must yield. As an examination of Marbury illustrates, the constitutional principle of judicial review is inconsistent with a privileged-conduct-only rule.

The general concept of the rule of law does not lead directly to the principle that a litigant has a right to be judged by a constitutionally valid rule, as Monaghan and Fallon appear to beheve; ${ }^{45}$ rather, the principle is a collateral consequence of Marbury's specific concept of the rule of law. Chief Justice Marshall's opirion in Marbury frames the ultimate question as follows: "If an act of the legislature, repugnant to the constitution, is void, does it, notwithstanding its invalidity, bind the courts, and oblige them to give it effect?"46 Throughout his opinion, Marshall focuses on the question whether the statute is consistent with the Constitution. And he concludes that "a law repugnant to the constitution is void." 47 Under this view, now canonized in American law, the very meaning of an enforceable constitution is that an unconstitutional law may not be enforced. ${ }^{48}$ As Alexander Hamilton wrote in Federalist No. 78, antici-

43. See Note, supra note 30 , at 848 .

44. Cf. Herbert Wechsler, Toward Neutral Principles of Constitutional Law, 73 HARv. L. REv. l, 36 (1959) (arguing that the Supreme Court has an unflagging obligation to exercise its authority to adjudicate constitutional questions).

45. See text accompanying notes 29-30 supra.

46. Marbury, 5 U.S. at 177 (emphasis added).

47. Id. at 180 (emphasis added).

48. Norton v. Shelby County, 118 U.S. 425 (1886), sets forth an extreme version of this basic postulate: "An unconstitutional act is not a law; it confers no rights; it imposes no duties; it affords no protection; it creates no office; it is, in legal contemplation, as inoperative as though it had never been passed." Id. at 442. A more moderate view posits that a judgment of unconstitutionality binds only in a judicial setting, leaving the "invalidated" statute on the books. See GunTHER, supra note 11, at 28 (explaining how the decision that a law is unconstitutional might merely suspend its enforcement until a later court reverses the decision); TRIBE, supra note 30, $\$ 3-3$, at $27-28$ (describing the view that judicial 


\section{pating Marbury:}

A constitution is in fact, and must be, regarded by the judges as a fundamental law. It therefore belongs to them to ascertain its meaming as well as the meaning of any particular act proceeding from the legislative body. If there should happen to be an irreconcileable [sic] variance between the two, that which has the superior obligation and validity ought of course to be preferred; or im other words, the constitution ought to be preferred to the statute . . . 49

\section{The Supremacy Clause and the Constitution.}

Apart from Marbury, the Constitution itself directs courts to focus on the constitutionality of a challenged statute rather than on the privileged or unprivileged character of the conduct of the litigant challenging it. The Supremacy Clause declares that the Constitution is supreme, "any Thing in the Constitution or Laws of any State to the Contrary notwithstanding." 50 Logically read, a "Thing" refers to a provision of law, not an application of that provision to privileged conduct. ${ }^{51}$ Applications, after all, arise not "in" laws, but, by definition, from applying then1. ${ }^{52}$ Thus, the First Amendinent proscribes the making of any "law" establishing religion or violating the freedoin of speech, the press, or assembly. A law which does so is unconstitutional.

The Constitution does not crcate, in so many words, an individual right to be judged only by a constitutional law. But the Constitution certainly forbids a court from enforcing an unconstitutional law. ${ }^{53}$ Courts, which will not enforce

pronouncement of unconstitutionality binds only the parties before the court). Still, even this narrower reading of Marbury acknowledges that-barring a reinterpretation of the statute or an overruling of the case invalidating it - so far as the judiciary is concerned, a statute that has been judged unconstitutional is no law at all, even if it remains visible to other government actors.

49. The Federalist No. 78, at 525 (Alexander Hamilton) (Jacob E. Cooke ed., 1961).

50. U.S. ConST. art. VI, cl. 2.

51. The clause applies by analogy to federal as well as state law.

52. I do not wish to suggest that an application of a facially valid law cannot be unconstitutional. It can, as for example, when the government enforces the law unevenly. See Yick Wo v. Hopkins, 118 U.S. 356, 373-74 (I886). But the Supremacy Clause directs itself primarily at unconstitutional laws; only derivatively does it prevent unconstitutional applications of constitutional laws.

53. The theory of judicial review underlying Marbury by no means limits itself to the United States Supreme Court. By its terms, the Supremacy Clause, the ultimate source of judicial authority to give the Constitution priority over contradictory statutes, applies to state judges. U.S. CoNST. art. VI, cl. 2. And, of course, Congress has empowered lower federal courts to adjudicate constitutional questions as well. See, e.g., 28 U.S.C. $\$ 1331$ (1988) (conferring original jurisdiction on district courts im civil actions arising under the Constitution).

Whether executive officials are forbidden from enforcing laws they deem unconstitutional presents a more difficult question. The President's oath to "preserve, protect and defend the Constitution," U.S. CoNST. art. II, $\S 1, \mathrm{cl} .8$, implies such a prohibition, but serious separation of powers issues could arise if the executive attempted to nullify putatively unconstitutional legislation except through the veto power or perhaps the pardon power. See generally TRIBE, supra note 30, § 4-12, at 256-62 (discussing legislative attempts to restrict executive power to impound congressionally appropriated funds). And in the administrative law realn, agency discretion limits the ability of so-called "enforeement courts" to give effect to constitutional imperatives. See Henry P. Monaghan, Marbury and the Administrative State, 83 Colum. L. REv. 1, 28-34 (1983) (arguing that administrative agency discretion effectively deprives courts of constitutional rulemaking authority); cf. Henry M. Hart, Jr., The Power of Congress to Limit the Jurisdiction of Federal Courts: An Exercise in Dialectic, 66 HARv. L. REv. 1362, 1377-78 (1953) (recognizing administrative agency discretion but enphasizing that agencies are not making "final determinations of questions of law"). 
unconstitutional laws, will treat litigants exactly as though they have a right to be judged only by constitutional rule of laws. In practice, therefore, every hitigant does have such a right. ${ }^{54}$

\section{Severability Doctrine}

If the principle that every litigant has a right to be judged by a constitutionally valid law follows naturally from Marbury and other constitutional precepts, how could the Court adopt a seemingly contrary principle in Yazoo and Salerno? The answer lies in severability doctrine.

To understand the relation between the Yazoo/Salerno holding and"severability doctrine, consider once again Monaghan's barroom dancing example. Recall our assumptions: (1) people have a constitutional right to dance in a barroom unless one is barefoot; and (2) a state statute prohibits all barroom dancing. Clearly, the statute is unconstitutional because the state may not forbid barroom dancing by persons who are not barefoot. If the state prosecutes Mr. Thoinpson for dancing barefoot in a barroom, must he go free?

The answer depends on whether the court treats the unconstitutional applications of the statute as severable from the constitutional ones. Suppose that the highest court of the state holds the statute unconstitutional as applied to persons who are not barefoot. That does not necessarily mean that the entire law must fall. The court might void the statute to the extent it criminalizes nonbarefooted dancing, but sever the remainder as valid-in essence, rewriting the statute. Prior to the court's ruling, the law read: "Barroom dancing shall be an offense." By ruling that the statute's unconstitutional applications are severable, the court essentially holds that the law has two parts. The first reads: "Barroom dancing shall be an offense if the dancer is not barefoot." The second reads: "Barroom dancing shall be an offense if the dancer is barefoot." Under this analysis, the second part of the statute stands on its own as a constitutionally valid law. Thus, the court would sustain Mr. Thompson's conviction under the statute because he is being judged by a valid rule-the newly severed second part of the statute.

Of course, the state court need not declare the first part of the statute invalid in order to sustain Mr. Thompson's conviction. Rather, it suffices to note that if the statute has unconstitutional applications, they are severable from the constitutional applications. The court need not decide whether the statute would be unconstitutional as applied to persons not before it.

The opinion in Yazoo takes precisely this form. Recall the railroad's argument: The Mississippi statute mandating fines for failure to settle claims was unconstitutional because it would require settlement of fraudulent and frivolous

54. Although refusals to give retroactive effect to a constitutional decision seemingly conflict with the valid rule requirement, they may be harmonized. For instance, one could interpret the Court's "new rule" of law nonretroactivity doctrine for habeas petitions, see Teague v. Lane, 489 U.S. 288 (1989) (plurality opinion), as an interpretation of 28 U.S.C. $\$ 2254$ (procedure for habeas petition), rather than the Constitution. But even recognizing nonretroactivity as an exception to the general requirement of a valid rule, the very controversy purely prospective rulings generate, see, e.g., James B. Beam Distilling Co. v. Georgia, 111 S. Ct. 2439 (1991), indicates the strength of the general requirement. 
claims. The Court, however, refused to rule on the constitutionality of the statute because the railroad did not contend that the claims the statute required them to settle were fraudulent or frivolous. Severability analysis reconciles Yazoo with the principle that every litigant has a right to be judged by a constitutionally valid law. Although the Court did not address severability in denying relief, it effectively presumed that, under Mississippi law, the state courts would sever any unconstitutional applications of the statute from the constitutional ones. Thus, the decision in Yazoo established a presumption that a statute's constitutional and unconstitutional applications are severable. 55

The severability presumption also explains the Salerno formulation. If we assume that the courts can sever the Bail Reform Act's unconstitutional applications from its constitutional applications, then one can only mount a successful facial challenge to the Act by showing that no set of circumstances exist under which it can be constitutionally applied. For, if the Act has any constitutional applications, a court should construe them as a separate, constitutional Act. Conversely, if a statute has no constitutional applications, then no statute remains after a court severs the unconstitutional applications.

Indeed, the Court applied the same presumption of severability in Marbury. In so doing, it showed how this presumption limits the principle that a litigant has a right to be judged under a constitutionally valid law. Despite the Marbury Court's statement that "an act of the legislature, repugnant to the constitution, is void," 56 it did not hold the Judiciary Act of 1789 void in its entirety. Instead, the Court apparently assumed that it could treat so much of the Act as authorized it to grant writs of mandamus without an additional basis for original Supreme Court jurisdiction as if it were a distinct unconstitutional provision. In other words, the Court implicitly held that the invalid provision was severable. ${ }^{57}$

55. See Paul M. Bator, Dantel J. Meltzer, Paul J. Mishkin \& David L. Shapiro, Hart \& Wechsler's The Federal Courts and the Federal System 178-81 (3d ed. 1988).

56. Marbury v. Madison, 5 U.S. (1 Cranch) 137, 177 (1803).

57. Even if no one had a right to be judged by a constitutionally valid law, ordinary principles of statutory construction and constitutional law would still often require courts to look beyond a litigant's own conduct in deciding whether to enforce a statute against her. Consider Monaghan's barroom dancing example one last time. When the state charges $\mathrm{Mr}$. Thompson under the no-barroom-dancing-underany-circumstances statute, he may no longer claim that the prosecution violates a valid rule requirement because we have assumed, arguendo, that no such right exists. However, he still has a potent defense. He may argue that, as a matter of state statutory construction, the court may not sever unconstitutional applications of the statute from its application to him. Thus, he may claim, the state seeks to prosecute him under an essentially nonexistent law-nonexistent because under state severability law, the entire statute is void. Whether Mr. Thompson prevails depends on exactly the same question that determines his success when we recognize a valid rule requirement: whether the statute's applications are severable.

Moreover, the absence of a valid rule requirement would not frustrate the ability of a litigant whose own conduct is not constitutionally protected to bring a facial challenge to a state statute in federal court. As a unamimous Court recognized in Franchise Tax Board v. Construction Laborers Vacation Trust, 463 U.S. 1 (1983), it is "well-settled" that a case arises under federal law for purposes of original jurisdiction in the federal district courts, "where the vindication of a right under state law necessarily turn[s] on some construction of federal law." Id. at 9. While "this statement must be read with caution," Merrell Dow Pharm., Inc. v. Thompson, 478 U.S. 804, 809 (1986), even under a restrictive view of original federal jurisdiction, a typical facial challenge would qualify as one in which federal law is "in the 
Courts cannot reduce every facial challenge to a severability question. As a doctrine of statutory construction, severability must defer to constitutional principles. In Part II of this article, I argue that, in many circumstances, overriding constitutional considerations trump severabihty doctrine. When they do not, however, facial challenge doctrine really boils down to severability doctrine combined with institutional limits on the Salerno presumption of severability, which I discuss in Part III.

\section{Constitutional Barriers to the Yazoo/Salerno Presumption OF SEVERABILITY}

Despite the apparent universality of the Court's pronouncement in Salerno, the presumption of severabihty does not apply in all contexts. Two limitations presently constrain the presumption's reach, one institutional and one substantive. I discuss the institutional restraints-the choice of forum and the source of the statute-and their implications in Part III. This Part addresses those limits to the presumption of severability that arise out of substantive constitutional law. The Court's treatment of underinclusive statutes in equal protection challenges implicitly rejects a Salerno-type approach. Furthermore, Salerno is inappropriate not just for First Amendment overbreadth doctrine, as the Court has acknowledged, but also for applications of overbreadth doctrine to fundamental rights outside of the First Amendment area. Finally, constitutional tests which turn on a statute's purpose rather than its application are inconsistent with a presumption of severability.

\section{A. Underinclusive Statutes and the Equal Protection Clause}

The Salerno presumption requires a court to focus only on the conduct of the parties before it, rather than on the conduct of third parties. Yet, by their terms, some constitutional provisions compel courts to compare the relative burdens on different actors. The Equal Protection Clause provides a prime example, and indeed, the Court has not applied the presumption of severability to equal protection cases involving underinclusive statutes. This may be due to the complexity inherent in deciding how to "sever" an underinclusive statute. Do courts expand its coverage- "sever" the exclusion of certain groups by including them-or nullify it-sever the "singhing out" of those covered by the law?

To illustrate, suppose a state statute reads: 'Littering shall be an offense if committed by African-Americans but not if committed by persons of other races." The statute is unconstitutional under the Fourteenth Amendment be-

forefront of the case and not collateral, peripheral or remote." Textile Workers Union v. Lincoln Mills, 353 U.S. 448, 470 (1957) (Frankfurter, J., dissenting).

Finally, the same argument applies to facial challenges to federal statutes. Whether the invalid applications of a federal statute are severable from its constitutional applications presents a question of federal statutory construction. Unconstitutional provisions of a nonseverable federal statute render it wholly unenforceable regardless of whether a right to be judged by a valid law exists.

In short, even if one rejects my Marbury-based argument for the valid rule requirement, severability principles still hold the key to understanding what is at stake when a litigant brings a facial challenge. 
cause it denies African-Americans equal treatment on account of their race. Suppose a litigant challenges the statute on its face. How might a court sever the unconstitutional apphications from the constitutional ones? One answer consistent with Yazoo and Salerno is that such a task is impossible: the statute has no constitutional apphications; by its terms, it does not apply to persons who are not African-Americans. Thus, if we try to sever the unconstitutional application to African-Americans, the remaining statute reads: "Littering shall be an offense if committed by African-Americans but not if committed by persons of other races, except that this statute shall not apply to African-Americans." We are left with a statute that prohibits nothing. This example illustrates the uncontroversial portion of the Salerno principle: A sufficient condition for a statute's facial invalidity is that it admits of no constitutional apphications.

Consider instead an alternative approach. Our original statute reads: "(1) Littering shall be an offense (2) if committed by African-Americans but not if committed by persons of other races." If we "sever" the second portion of the statute, the resulting statute is plainly constitutional. The statute now prohibits littering, regardless of the litterer's race.

Although this second method of severance may seem somewhat odd, it more closely addresses the constitutional problem than does the first. The vice of the original statute lies in that it applies only to African-Americans, and is thus underinclusive. It should not be surprisnig that judges will not satisfactorily cure underinclusiveness by making a statute less inclusive. Instead, the more obvious method of saving an underinclusive statute is to make it more inclusive.

Severance by expansion comes closer to conventional severance than severance by nullification. In severing unconstitutional portions of a statute one seeks to preserve as much of the statute as possible. Thus, broadening the statute accomplishes this goal, ${ }^{58}$ whereas whittling the statute down to nothing does not. Severance by nullification kills the patient along with the disease.

Nothing in the Equal Protection Clause ${ }^{59}$ prevents courts from curing an underinclusive statute by expanding its coverage. ${ }^{60}$ Although there may be reasons to prefer expanding a provision's scope to eliminating it, such decisions are based on principles of statutory interpretation, not constitutional law. ${ }^{61}$

58. Indeed, one might argue that more of the statute is "preserved" than the legislature enacted.

59. As a matter of statutory construction, one might reasonably object to adding provisions to cure a statute's constitutional flaws because it borders on judicial legislation and is at odds with the view that judges should give statutes the meaning their text supports. But the objection applies with equal force to the practice of severing an unconstitutional application by reading in an exception. In short, the argument against creatively construing a statute to cure a constitutional defect or avoid a constitutional question, however persuasive, presents a general objection. It holds no greater or lesser force in equal protection cases.

60. One commentator has noted: "Where a statute denies equal protection by making an unconstitutional classification, the classification can be abolished by making the statute operate either on everyone or on no one." Developments in the Law-Equal Protection, 82 HARv. L. Rev. 1065, 1136 (I969).

61. The Court has, for example, tended to remedy underinclusive federal benefit statutes by expanding the class of beneficiaries. See Califano v. Westcott, 443 U.S. 76, 89-9I (1979) (gender discrimination in welfare benefits); Jimenez v. Weinberger, 417 U.S. 628, 637-38 (1974) (disability benefits for illegitimate children of disabled parents); Frontiero v. Richardson, 411 U.S. 677, 691 \& n.25 (1973) 
Thus, in Skinner v. Oklahoma ex rel. Williamson, ${ }^{62}$ after ruling unconstitutional an Oklahoma law that authorized the sterilization of habitual offenders but exempted crimes such as embezzlement, the Supreme Court remanded the case and let the Oklahoma courts decide whether to void the sterihzation provision or to extend it. 63

Skinner illustrates that courts do not apply the Salerno presumption of severability in the context of underinclusiveness equal protection cases. Recall that in an underinclusiveness challenge, a determination that the discriminatory portion of the statute is severable means that courts will expand the statute's coverage. In Skinner, had the Court employed the Salerno presumption, it would have assumed that the discriminatory portion of the statute could be severed and remedied any constitutional defect by expanding the statute's coverage beyond the classified group. Consequently, the Court would have denied Skinner relief because the presumptive remedy-extending the statute to all habitual offenders-would not have benefitted him. In fact, the opposite happened: On remand, the Oklahoma Supreme Court held the sterilization provision void in its entirety, with the result that Skinner avoided sterilization. ${ }^{64}$

\section{Contrasting Orr v. Orr with the Salerno presumption.}

As Skinner illustrates, in deciding equal protection challenges to underinclusive statutes, the Court's approach differs from what the Salerno presumption would suggest. In fact, in another equal protection case, Orr v. Orr, ${ }^{65}$ the Court came close to adopting the opposite presumption. In Orr, an Alabama man defending a charge of contempt of court for failure to pay alimony under an Alabama statute argued that he should not have to pay alimony to his exwife because the statute violated equal protection by permitting alimony awards against men but not women. Mrs. Orr argued that the court should not permit Mr. Orr to make this argument because he had not actually sought alimony. In her view, he impermissibly sought to invoke the equal protection rights of a party not before the court. The Supreme Court rejected this argument and stated:

In every equal protection attack upon a statute challenged as underinclusive, the State may satisfy the Constitution's commands either by extending benefits to the previously disfavored class or by denying benefits to both parties .... Because we have no way of knowing how the State will in fact respond, unless we are to hold that underinclusive statutes can never be challenged because any plaintiff's success can theoretically be thwarted, Mr. Orr must be held to have

(plurality opinion) (dependency allowance for husbands of armed forces members). But the remedy clearly does not rise to a constitutional level: In cases involving state benefit statutes, the Court typically remands the remedial question to the state courts. See, e.g., Wengler v. Druggists Mut. Ins. Co., 446 U.S. 142, 153 (1980) (refusing to decide whether to expand or nullify a state workers' compensation program).

62. 316 U.S. 535 (1942).

63. Id. at 543 .

64. Skinner v. State ex rel. Williamson, 195 Okla. 106, 106-07, 155 P.2d 715, 716 (1945).

65. 440 U.S. 268 (1979). 
standing here. 66

Thus, at least for justiciability purposes, in Orr the Court presumes nonseverability, presenting a clear contrast with the Salerno approach. Moreover, Orr is liardly aberrational. The Supreme Court las applied similar logic to underinclusive statutes clallenged under other constitutional provisions that mandate equal treatment, sucl as the guarantee of free speecli ${ }^{67}$ and the prohibition against the establishment of religion. 68

The Orr approacl allows adjudication of the merits of an underinclusiveness cliallenge, regardless of whether a successful challenge would render the litigant eligible for relief. In this respect, $O r r$ avoids the draconian effect of Salerno, denying relief to a litigant bringing a facial challenge to a statute which has both constitutional and unconstitutional applications. Orr does not require that a litigant who brings an equal protection challenge to an underinclusive statute be granted relief. It only requires that the constitutional question be decided, leaving open the possibility that the court will deny the challenger relief after she prevails on her constitutional claim.

There is one sense in which Orr departs from established practice. Ordinarily when a litigant seeks relief from an alleged constitutional violation, courts may opt to avoid deciding the constitutional question if independent grounds exist to deny the litigant relief. ${ }^{69}$ Thus, in a case like $O r r$, we would expect the court to decide the remedy question first, and reach the equal protection question only if it finds that the remedy for such a violation would benefit the challenger. This course would comport with the principle of constitutional avoidance-that courts should refrain from unnecessarily deciding constitutional matters.

The Court followed the opposite course in Orr purportedly because it had "no way of knowing" how the Alabama courts would remedy the alimony statute's underinclusiveness. ${ }^{70}$ Its reasoning, however, is disingenuous: In deciding federal questions, federal courts often make preliminary determinations of state law. ${ }^{71}$ The fact that a state's highest court may overrule a federal court's

66. Id. at 272 (emphasis in original).

67. Arkansas Writers' Project, Inc. v. Ragland, 481 U.S. 221, 227 (1987) (denying standing to plaintiff "would effectively insulate underinclusive statutes from constitutional challenge").

68. See Texas Monthly, Inc. v. Bullock, 489 U.S. 1, 8 (1989) (plurality opinion) (citing Orr and Arkansas Writers' Project as the basis for granting standing to plaintiff to challenge state's tax exemption for religious periodicals). The principle that the Establishment Clause contains a miniature equal protection requirement is not undermined by Edwards v. Aguillard, 482 U.S. 578 (1987), in which the Court held as facially invalid Louisiana's "Balanced Treatment for Creation-Science and EvolutionScience in Public School Instruction Act." In that case, the Court held that although the Act purported to be neutral, its real purpose was "to give preference to those religious groups which have as one of their tenets the creation of humankind by a divine creator." Id. at 593. Thus, the Court's holding fits comfortably with what Justice Harlan termed the "neutrality" norm of the Establishment Clause requiring that the government neither favor religion over nonreligion nor sponsor a particular sect. Walz $\mathrm{v}$. Tax Comm'n, 397 U.S. 664, 696 (1970) (Harlan, J., concurring).

69. See, e.g., Teague v. Lane, 489 U.S. 288, 297-99 (1989) (defendant barred from unounting Equal Protection Clause claim because of nonretroactivity principle).

70. 440 U.S. at 272.

71. For example, while federal law governs whether a litigant received adequate procedural due process, state law determines whether a particular entitlement can be considered property in the first 
resolution of a state law question means only that the federal court cannot know with certainty how the state courts would remedy an underinclusiveness problem. In fact, if state law clearly dictates that underinclusiveness be cured by expansion, rendering a successful challenger ineligible for relief, a federal court could avoid deciding the difficult constitutional question by dismissing the claim on that basis.

Moreover, the Court's statement in Orr that "any plaintiff's success can theoretically be thwarted" by a remedy of expanded coverage 72 misses a central point. In order to thwart her husband's potential remedy, Mrs. Orr did not need the Court to apply an irrebuttable presumption that all underinclusive Alabaina statutes will be remedied by expansion; she only needed to show that expansion would remedy this particular Alabama statute. In other cases, litigants may show that not applying the statute to anyone is the only remedy for that statute's underinclusiveness.

Federalism may explain the practice adopted in Orr. The decision reflects a judgment that the risk of incorrectly guessing that a state will choose a remedy that does not benefit the statute's challenger outweighs the harm of unnecessarily deciding a constitutional question. In addition, the countervaihing policy of avoiding unnecessary decisions of state law supports the Orr approach. ${ }^{73}$ Thus, one might read the rule of $O r r$ as representing a triumph of institutional concerns over the severability principle.

Nevertheless, courts do not uniformly recognize federalisin as the true basis for Orr. If federalism concerns did in fact drive the Orr policy of permitting one who may not benefit froin the ultinate remedy to bring an equal protection challenge, we would expect to see a different approach when the court deciding the equal protection claim also has final authority over the remedy. For instance, when a litigant challenges a state law on underinclusiveness grounds in state court, the court could decide that broademing the statute's scope is the appropriate remedy under state law and that it need not reach the federal constitutional question. In flnding a statute underinclusive, the state's highest court, by defimition, cannot "guess incorrectly" as to the appropriate remedy under state law. Moreover, no principle constrains state courts from deciding questions of state law. Similar principles should apply when litigants challenge underinclusive federal statutes in federal court. ${ }^{74}$ In a case involving a challenge to a federal statute, a federal court would not risk denying relief to an

place. Thus, in deciding whether a state violated a litigant's right to procedural due process, a federal court will often need to decide first whether state law recognizes the interest in question as "property." See, e.g., Cleveland Bd. of Educ. v. Loudermill, 470 U.S. 532, 538-41 (1985) (determining first that plaintiffs possessed state property rights in continued enployment before deciding whether termination procedures met federal due process requirements). See generally BATOR ET AL., supra note 55, at 575S0 (discussing the extent to which state law controls in due process challenges).

72. 440 U.S. at 272.

73. See, e.g., Harman v. Forssenius, 380 U.S. 528, 534 (1965). See generally Martha A. Field, Abstention in Constitutional Cases: The Scope of the Pullman Abstention Doctrine, 122 U. PA. L. REv. 1071 (1974).

74. Although the Equal Protection Clause of the Fourteenth Amendment does not apply to the federal government, the Due Process Clause of the Fifth Amendnent "incorporates" an equal protection component that is applicable to the federal government. See Bolling v. Sharpe, 347 U.S. 497 (1954). 
otherwise worthy claimant if it were to determine the remedial question before reaching the constitutional one.

Despite Orr's apparent basis in federalism, the Court has not treated underinclusiveness challenges to federal statutes differently from such challenges to state statutes. Even then-Justice Rehnquist, who dissented in Orr on other grounds, accepted a line of cases holding that the Court may decide the merits of a case, even if Congress is "capable of frustrating a victory" by choosing a remedy which does not benefit the litigant before the Court. ${ }^{75}$

Similarly, state courts apply the Orr method to underinclusiveness challenges to state statutes. In People v. Liberta, ${ }^{76}$ for example, the highest court of New York sustained an underinclusiveness challenge to the state's rape law, which included an exemption for spousal rape. After Liberta was convicted of raping a woman who was not considered his wife under the statute, ${ }^{77}$ he attacked the law on equal protection grounds, claiming that the statute treated him differently from men who raped their wives. Citing Orr and Skinner, the court first noted that "[a] litigant has standing to raise [an underinclusiveness] claim even though he does not contend that under no circumstances could the burden of the statute be imposed upon him."78 The court next found that the marital exemption violated both federal and state Equal Protection Clauses. ${ }^{79}$ Only then did the court analyze the remedy question, holding that the legislature, if faced with the choice, would probably extend prohibition of rape to married persons, rather than abolish the crime altogether, leaving imtact that portion of the statute under which Liberta was convicted. Thus, Liberta's equal protection argument won him a pyrrhic victory. ${ }^{80}$ The opinion never mentions

75. Orr, 440 U.S. at 292 (Rehnquist, J., dissenting) (citing Califano v. Webster, 430 U.S. 313 (1977)); see also Califano v. Goldfarb, 430 U.S. 199 (1977); Frontiero v. Richardson, 411 U.S. 677 (1973). Heckler v. Mathews, 465 U.S. 728 (1984), provides the most extreme example of this principle. There, the Court permitted a nondependent husband to challenge a Social Security Act provision that made dependency an eligibility requirement for husbands' benefits, but not for wives'. The Court adjudicated the merits even though a severability clause in the statute expressly stated that, if the provision were found invalid, benefits would not be extended to nondependents of either sex. (1985).

76. 64 N.Y.2d 152, 474 N.E.2d 567, 485 N.Y.S.2d 207 (1984), cert. denied, 471 U.S. 1020

77. In fact, Liberta raped his wife, but at the time of the offense he vras under a court order to stay away from her. In accordance with the statute, the court treated Liberta as if he raped a voman to whom he was not married. 474 N.E.2d at 571.

78. Id.

79. Id. at 572-75. The court based its lolding on the conclusion that "there is no rational basis for distinguishing between marital rape and nonmarital rape." Id. at 573. Considering the extreme deference with which courts ordinarily apply rationality review, see Ferguson v. Skrupa, 372 U.S. 726, 72829 (1963); Williamson v. Lee Optical, 348 U.S. 483, 488-91 (1955), one may question the court's logic. Nonetheless, heightened scrutiny justifies the decision. As a matter of due process, requiring that a woman forfeit control of her body as a precondition to exercising her right to marry places an unconstitutional burden on that right. Furthermore, as a matter of equal protection, the marital rape exemption rests on a view of women which is inconsistent with the basic principle that women are full members of American society. Cf. Planned Parenthood v. Casey, 112 S. Ct. 2791, 2831 (1992) ("A State may not give to a man the kind of dominion over his wife that parents exercise over their children."). For more detailed analyses of the constitutionality of the marital rape exemption, see Robin West, Equality Theory, Marital Rape, and the Promise of the Fourteenth Amendment, 42 U. FLA. L. REv. 45 (1990); Note, To Have and to Hold: The Marital Rape Exemption and the Fourteenth Amendment, 99 HARV. L. REv. 1255 (1986).

80. 474 N.E.2d at 578-80. This outcome illustrates the odd principle, endorsed in $O r r$, that a court 
the possibility that the court might have addressed the remedial issue before the substantive equal protection question.

We have seen that for underinclusiveness claims, a litigant may challenge a statute even if the ultimate remedy would be to expand its coverage in a way that does not benefit her. In contrast, for overinclusiveness cases, the Salerno rule prohibits a litigant from challenging a statute if the ultimate remedy would be to sever the unconstitutional applications in a manner that precludes relief. What justifies the difference? One might hypothesize that some fundamental difference between underinclusiveness and overinclusiveness complaints explams Orr's contrast with the Salerno principle, but none of the cases discussed so far suggests why such a difference supports the standing rules the Court has adopted. Both remedial questions-whether to cure an underinclusive statute by expansion or nullification and whether to cure an overinclusive statute by severance or nullification-present issues of statutory interpretation. Yet nowhere does the Court indicate why, as a matter of state or federal principles of statutory construction, different presumptions should be employed for the two kinds of challenges.

\section{R.A.V. and the underinclusive/overinclusive distinction.}

One recent Supreme Court case provides insight into a plausible rationale for treating standing differently in underinclusiveness and overinclusiveness challenges. In R.A.V. v. City of St. Paul, ${ }^{81}$ the Court held facially invalid an ordinance that prohibited displaying a symbol known to "arouse anger, alarm, or resentment in others on the basis of race, color, creed, religion, or gender."82 The Minnesota Supreme Court construed the ordinance to reach only "fighting words," a class of speech not protected under the First Amendment. The United States Supreme Court, however, ruled that the state may proscribe all fighting words, but not a subset of fighting words based on content. ${ }^{83}$ Concurring in the judgment, Justice White, joined by three other Justices, severely criticized what he termed the majority's novel "underbreadth" analysis. ${ }^{84}$ The

may remedy a past equal protection violation by equal treatment in the future. A man who raped his wife after the Liberta decision may be punished under the New York rape law. However, because due process requires notice, persons who raped their wives prior to that decision may not be prosecuted for rape because the statute at the time clearly exempted them. The remedy of prospective severance fails to address Liberta's equal protection concern that a man who committed marital rape at the same time Liberta committed nonmarital rape is unfairly advantaged under the law. The New York Court of Appeals attempts to resolve this problem by breaking down Liberta's equal protection claim into two separate claims: (1) unequal treatment of marital and nonmarital rapists; and (2) unequal treatment of marital rapists before and after the announcement of the decision. The court states that prospective abolition of the marital rape exemption cures the first defect, and that the second imequity survives rational basis scrutiny because it vindicates the constitutional requirement of notice. Id. at 579-80. Not benefitting from the remedy, Liberta actually won a hollow victory. No doubt the New York Court of Appeals believed he deserved no more.

81. 112 S. Ct. 2538 (1992).

82. Id. at 2541 .

83. For an unconventional approach to the issues presented by R.A.V., see Akhil Reed Amar, Comment, The Case of the Missing Amendments: R.A.V. v. City of St. Paul, 106 HARv. L. Rev. 124 (1992).

84. 112 S. Ct. at 2553 (White, J., concurring). 
majority retorted that "the First Amendment imposes not an 'underinclusiveness' limitation but a 'content discrimination' limitation upon a State's prohibition of proscribable speech." 85 Implicit in this response is the following argument:

The Free Speech Clause of the First Amendment prohibits the government from punishing expression based on hostility to its content. Courts prohibit content discrimination even when limited to a category of unprotected speech, such as fighting words. Punishing $\mathrm{X}$ for the content of lier speech constitutes unequal treatment of $X$, not because the government fails to punish others for their unprotected speech, but because it singles her out based on an illicit criterion. Although the statute proscribing X's speech may be "underinclusive," its unconstitutionality stems not from its underinclusive nature, but from its treatment of $\mathrm{X}$ herself.

One need not strain analysis to apply the structure of this argument to equal protection claims as well. ${ }^{86}$ The analogous argument runs as follows:

The Equal Protection Clause prohibits the government from punishing an individual based on membership in a group defined by a suspect classification, such as race. Courts prohibit such discrimination even when limited to unprotected conduct such as littering. Punishing $\mathrm{X}$ for her race (or membership in a group defined by some other suspect classification) constitutes unequal treatment of $\mathrm{X}$, not because the government fails to punish others for littering, but because it singles her out based on membership in a group defined by a suspect classification. Although the statute punishing X's conduct may be "underinclusive," its unconstitutionality stems not from its underinclusive nature, but from its treatment of $\mathrm{X}$ herself.

The Court apparently accepts this reasoning, subject only to the caveat that a court may ultimately deny relief to the litigant who mounts a successful underinclusiveness challenge. Under current constitutional doctrine, a litigant who makes an underinclusiveness challenge--whether based on the Equal Protection Clause or sone other constitutional norin ${ }^{87}$-need not face the kind of preliminary hurdle which Yazoo and Salerno purport to require for overinclusiveness challenges. Yet, notwithstanding the current state of the law, the argument 1 have drawn froin $R . A . V$. remains difficult to sustain.

85. Id. at 2545 (opinion of the Court).

86. For a discussion of the relationship between the First Amendment and the principle of equal treatment, see Amar, supra note 83, at 130 n.46; Kenneth L. Karst, Equality as a Central Principle in the First Amendment, 43 U. CHI. L. Rev. 20 (1975).

87. One can construct analogous arguments for other constitutional norms containing an equal protection component, such as the Free Exercise Clause and the Establishment Clause. See Church of Lukumi Babalu Aye v. City of Hialeah, 113 S. Ct. 2217 (1993) (holding unconstitutional a series of ordinances prohibiting ritual animal sacrifice because the ordinances targeted the Santeria rehigion); Employment Div., Or. Dep't of Human Resources v. Smith, 494 U.S. 872, 877 (1990) (holding that a state law of general applicability denying unemployment benefits to Native Americans fired for using an illegal drug (peyote) for religious purposes does not trigger heightened scrutiny, but noting the unconstitutionality of a law prohibiting acts "only when they are engaged in for religious reasons"). The Court's approach to free exercise claims in Church of Lukumi and Smith is very much at odds with the Salemo standard, because the Court asks only whether the law at issue is neutral, treating its application to the persons affected by it as essentially irrelevant. See note 68 supra (discussing "underinclusiveness" in Establishment Clause cases). 
Consider a hypothetical statute that punishes people for littering on property owned by white persons but not on property owned by persons of a different race. The statute violates equal protection because it employs a race-based classification that is not narrowly tailored to a compelling state interest. Suppose the state charges a white defendant with littering on another white person's property. The defendant would base her equal protection objection on the fact that had she littered on a nonwhite person's property she would not have committed an offense. She would claim that the court should apply strict scrutiny because ouly the race of her victim distinguishes her from a litterer on nonwhite-owned property.

Notably, our hypothetical litterer cannot rely on the view expressed above that challenges to underinclusiveness involve personal rights. The law does not single her out based on her race. Rather, the statute singles out nonwhite property owners by denying them the protection against litterers that their white counterparts receive. The law classifies property owners, not the defendant, based on race. ${ }^{88}$

Courts, however, have not treated this distinction-between laws that use a suspect classification to describe the victim and those that use one to describe the defendant-as significant. Liberta illustrates this point. The class truly aggrieved by the marital rape exemption consists of married women denied the protection against rape afforded to unmarried women. ${ }^{89}$ Nonetheless, New York's highest court treated the case as one invoking the defendant's right to equal protection.

A litigant can always formulate her claim so that it appears that an underinclusive statute singles her out in an illicit manner based on a characteristic of her person or her conduct by describing her status or conduct in a manner which incorporates the impermissible underinclusiveness. The cross-burner in R.A.V. claims that the law singles out his conduct because he directed it against people protected because of their race. The rapist in Liberta complains that the criminal code singles out his conduct because he directed it against a woman who was not his wife. And the litterer in my hypothetical exainple suggests that the law singles her out because of her victim's race. Yet, unlike the African-American punished for littering under a statute that makes littering a crime only if committed by an African-American, the impermissible discrimination evoked in each of these cases has nothing to do with the perpetrator.

A more sensitive approach to equal protection and related cases would recognize the inherent difference between cases in which a litigant claims that a

88. This does not mean that the white defendant cannot challenge the statute. She may show that the distinction between her and the person who litters on nonwhite-owned property is irrational, and therefore unconstitutional. Yet, we can imagine a lamentable situation in which the distinction would be rational. Suppose, for instanee, that a white population lives in a community segregated from other races, and that some local condition makes litter a particularly hazardous health risk in the white part of town but not elsewhere. The municipality might "rationally" use race as a proxy for locale in targeting its ordinance to the problem.

89. Alternatively, one might define the aggrieved class as women generally. By relying on and perpetuating sexist stereotypes of women's status vis-à-vis their husbands, the marital rape exemption treats all women as inferior to men. See note 79 supra. 
statute singles her out based on an illicit criterion and those in which she asserts that the law has unfair discriminatory effects on others. Statutory construction questions aside, courts should treat the latter category of cases as equivalent to cases in which a litigant challenges an unconstitutional rule of law, although its unconstitutionality does not stem from its effect on the hitigant. In other words, courts should treat the latter group of underinclusiveness cases similarly to cases of overinclusiveness. ${ }^{90}$

Most likely, the Court has failed to recognize the proposed distinction because, as a matter of substantive constitutional law, it views the drawing of various nonneutral lines as a constitutional violation, irrespective of the practical effect those lines have on the affected persons. ${ }^{91}$ This view conforms with the Court's free speech jurisprudence, which tends to stress the value of speech itself, apart from the rights of individual speakers. ${ }^{92}$ By analogy, the real issue in any equal protection case (or any other case involving neutrality norms) hinges on whether the statute uses an improper classification, apart from how it classifies the individual litigant. If the Court labels the classification itself as the harm, then the statute structurally violates the Constitution, and all litigants invoking the inproper classification claim something other than a personal right.93 This would explain the Court's view in Orr that all equal protection challenges must stand or fall together, but is difficult to square with the majority's rejoinder to Justice White in R.A.V. ${ }^{94}$

Whatever the reason, the Court does not treat underinclusiveness challenges the same way that Salerno purports to treat overinclusiveness challenges. While the Court might justifiably distinguish between underinclusiveness chal-

90. As I explain in greater detail throughout this article, I do not endorse the application of the Salerno presumption in the latter category of cases.

91. Dissenting in McCleskey v. Kemp, 481 U.S. 279, 336 (1987), Justice Brennan implied that, in lis view, there is no constitutional difference between being singled out based upon one's own race and being singled out based on the race of one's victim.

92. This notion underlies the First Amendment right to receive information, see Kleindienst v. Mandel, 408 U.S. 753 (1972); Lamont v. Postunaster General, 381 U.S. 301 (1965) (striking down a statute for placing unconstitutional limits on First Aınendinent rights by imposing an affirmative obhigation on the addressees of foreign "communist propaganda" inail to request receipt before the Postunaster would deliver), as well as the principle that the First Amendment protects speecli by corporations, see Austin v. Michigan Chamber of Commerce, 494 U.S. 652, 668 (1990) (applying strict scrutiny and sustaining a requirement that corporate independent expenditures be inade from a segregated fund); First Nat'l Bank of Boston v. Bellotti, 435 U.S. 765, 776 (1978) ("The proper question . . . is not whether corporations 'have' First Amendment rights and, if so, whether they are coextensive with those of natural persons. Instead, the question inust be whether [the law] abridges expression that the First Amendinent was ineant to protect.").

93. Shaw v. Reno, 113 S. Ct. 2816 (1993), provides dramatic confirmation of this view of equal protection. In Shaw, the Court held that white plaintiffs inay state an equal protection claim by alleging that reapportionment legislation is designed "so extremely irregular[ly] on its face" as to separate voters by race without sufficient justification. Id. at 2824 . The harm in Shaw is, quite literally, the draving of lines based on race. But see id. at 2834-37 (White, J., joined by Blackmun and Stevens, JJ., dissenting) (contending that the plaintiffs had not suffered a coginzable injury).

94. See text accompanying notes 81-85 supra. The difference might be explained by distinguisling between the Equal Protection Clause and the Free Speech Clause. Both Clauses contain a neutrality norm, but the Free Speech Clause contains an additional individual rights norm. On this view, content discrimination is prohibited not only because it requires the drawing of nonneutral lines, bnt also because it is censorship-an infringement of the individual rights of the speaker. 
lenges involving the litigant's traits from those involving traits of a third party, the Court treats all underinclusiveness clallenges in the same manner. Simply stated, the Court's unawareness of its inconsistent treatment of underinclusiveness and overinclusiveness may best explain this discrepancy. At present, we know that, whatever else its scope, the Salerno presumption does not apply to underinclusiveness cliallenges.

\section{B. Overbreadth Doctrine and the Salerno Principle}

The Court has expressly recognized that one substantive constitutional norm, the First Amendment's protection of free speech, is inappropriate for the application of the Salerno rule. As the Court stated in Salerno itself, First Amendnient "overbreadth" doctrine-which holds that a litigant may claim that a statute should not be applied to her solely because it would be unconstitutional to apply it to a third party not before the court-warrants the facial invalidation of a statute in exception to the Salerno principle. ${ }^{95}$ Although the Salerno Court correctly recognizes this overbreadth doctrine, it incorrectly assumes that it has no application outside the First Amendment arena. As I show in this section, an examination of First Amendment overbreadth doctrine reveals that its special standing conponent and concerns about the "chilling" effects of overbroad laws have properly been applied in other fundamental rights cases. With this in mind, I define the proper scope of overbreadth doctrine and apply my analysis to one right outside the free speech context-the right to abortion.

\section{The special standing component to First Amendment overbreadth doctrine.}

Two rationales for First Amendment overbreadth doctrine dominate the academic literature. According to one view, because overbroad laws have a chilhing effect on the expressive rights of parties not directly threatened by coercive action, litigants should have special standing to assert third parties' rights. ${ }^{96}$

95. 481 U.S. 739, 745 (1987).

96. See, e.g., R.A.V. v. City of St. Paul, 112 S. Ct. 2538, 2553 (1992) (White, J., concurring in the judgment) ("The overbreadth doctrine has the redeeming virtue of attempting to avoid the chilling of protected expression."); GUNTHER, supra note 11, at 1191-92. For a thoughtful discussion of the chilling effect, see Frederick Schauer, Fear, Risk and the First Amendment: Unraveling the "Chilling Effect," 58 B.U. L. REv. 685 (1978) (arguing that the chilling effect doctrine is a sound response to uneertainty in the legal process and the judgment that free speech is a preferred value).

Fallon identifies another justification for a special First Amendment overbreadth doctrine based on concern about danger of selective enforcement of laws regulating conduct protected by the First Amendment. Fallon, supra note 30 , at 884 .

The risk, however, that an overbroad statute will cloak legislative pursuit of illegitimate ends or unbridled prosecutorial discretion, see id., is not unique to situations involving First Amendment rights or even fundamental rights generally. Indeed, the Court has noted that the Due Process Clause's prohibition on vague laws responds particularly to the danger of selective enforcement. See, e.g., Kolender v. Lawson, 461 U.S. 352, 357-58 (1983) ("[T]he void for vagueness doctrine requires that a penal statute define the criminal offense with sufficient definiteness ... in a manner that does not encourage arbitrary and discriminatory enforcement."). The substantive law of vagueness does not require an exception to the Salemo presumption; indeed, it contains its own version. It is well estabhished that a litigant whose conduct is clearly proscribed by a statute cannot complain that the statute would be ambiguous as ap- 
Typically, adherents of this approach claim that the ordinary case-by-case narrowing of a law with potentially unconstitutional apphications is inadequate to protects First Amendment rights; ${ }^{97}$ if citizens believe that a statute prohibits activity protected by the First Amendment, they will censor themselves. ${ }^{98}$ In short, under this argument, the Constitution requires a presumption of nonseverability where rights of expression are concerned.

Under a second view, associated with Professor Monaghan, First Amendment overbreadth doctrine does not stand as an exception to the ordinary approach to statutes with both constitutional and unconstitutional applications. 99 Rather, "[o]verbreadth simply expresses th[e] requirement of a substantively valid rule in the context of First Amendinent substantive law."100 This approach requires no special standing rules. Instead, First Amendinent overbreadth doctrine follows automatically from substantive First Amendinent doctrine. ${ }^{101}$ In particular, the Court's invalidation of overbroad laws reflects the substantive First Amendment principle that laws regulating expression be the "least restrictive means" of accomplishing their ends. ${ }^{102}$ A law that interferes with protected expressive activity cannot be the least restrictive means of prohibiting proscribable activity, and, according to Monaghan, the Court consequently strikes down such laws. ${ }^{103}$

Monaghan's account of overbreadth doctrine leads logically to the conclu-

plied to a third party. See, e.g., Parker v. Levy, 417 U.S. 733, 756 (1974) ("One to whose conduct a statute clearly apphes may not successfully challenge it for vagueness."). Only a statute which is so vague as to provide no "ascertainable standard" for inclusion or exclusion, and thus has no core applications, will be invalidated as facially vague. E.g., Coates v. City of Cincinnati, 402 U.S. 611,614 (1971) ("[T]his ordinance is unconstitutionally vague because it subjects the exercise of the right to asseinbly to an unascertainable standard, and unconstitutionally broad because it authorizes the punishment of constitutionally protected conduct."); see also TrIBE, supra note 30, § 1232, at 1036. Accordingly, I do not treat selective enforcement as a unique First Aunendment issue.

97. See, e.g., TRIBE, supra note $30, \S 1227$, at 1023 ("[G]radually cutting away the unconstitutional aspects of a statute by invalidating its improper applications case by case ... does not respond sufficiently to the pecuharly vulnerable character of activities protected by the first amendment."); Note, supra note 30 , at $865-82$.

98. Some critics have found the conventional account of the chilling effect and the overbreadth solution unconvincing on the ground that most citizens are unaware of laws regulating expression, inuch less of their judicial constructions. See, e.g., Martin H. Redish, The Warren Court, the Burger Court and the First Amendment Overbreadth Doctrine, 78 Nw. U. L. Rev. 1031, 1040-41 (1984); Note, Overbreadth Review and the Burger Court, 49 N.Y.U. L. REv. 532, 546 (1974). The assumption that people know the law so pervades our law, however, that any convincing critique of a legal doctrine must do more than point out that the assumption sounetimes runs counter to fact. Moreover, in soine cases, individuals likely to feel the chill of an overbroad law-such as government employees fearful of losing their jobs if they speak out-1nay have access to organizations-such as labor unions-capable of developing hitigation strategies that take advantage of overbreadth doctrine. Fallon, supra note 30 , at $886-$ 89. Overbreadth doetrine thus effectively responds to the very real threat that overbroad laws pose to free expression.

99. See Monaghan, supra note 24, at 12-14; Henry Monaghan, Third Party Standing, 84 Colum. L. REv. 277, 282-86 (1984); see also BATOR ET AL., supra note 55, at 174 \& n.6 (listing earlier sources providing suggestions along similar lines).

100. Monaghan, supra note 24 , at 24 ; accord TRIBE, supra note $30, \S 1227$, at $1023-24$.

101. See Monaghan, supra note 24 , at 21-22.

102. Id. at 23, $37 \&$ n.152; accord GUNTHER, supra note 11 , at 1201-02.

103. Monaghan's atteinpt to ground overbreadth doctrine in substantive constitutional law is connected to his einphasis on the right to be judged by a constitutionally valid law. For, in the end, there may be no constitutionally privileged acts; the state may infringe even rights of expression if it narrowly 
sion that the doctrine is also appropriate wherever the least-restrictive-means analysis appears. Since the least-restrictive-means test serves as an essential component of strict scrutiny, which apphes to all fundamental rights cases, under Monaghan's approach, all laws burdening fundamental rights should trigger overbreadth analysis. ${ }^{104}$

Monaghan also argues that the Court permits state courts to construe and sever statutory provisions regarding speech as it does in other areas. ${ }^{105}$ Thus, he finds no special rule of nonseverability in the First Amendment area. Monaghan wrongly concludes, however, that the absence of nonseverability rules also implies an absence of a special standing component to the Court's overbreadth cases.

Case law only partially supports Monaghan's view that overbreadth doctrine merely reflects substantive constitutional law, ${ }^{106}$ and Professor Fallon observes that Monaghan's account of overbreadth doctrine contradicts what the Supreme Court and lower courts actually do in overbreadth cases. ${ }^{107}$ Fallon posits that courts do indeed employ a distinctive standing conponent to First Amendnient overbreadth doctrine, although it may not operate as a general rule of nonseverability. ${ }^{108}$ Fallon describes and justifies this special standing principle by analyzing numerous First Amendnient cases in which the Court facially invalidates an overbroad statute expressly because of the concern that, although constitutionally applicable to the litigant before the Court, it would chill the expressive rights of others. ${ }^{109}$ In addition, he argues that the Court has

tailors its regulation to serve a compelling state interest. What inatters in each case is the government's reason for regulation, or in other words, the rule of law applied.

104. $C f$. Jones v. Helms, 452 U.S. 412, 424-26 (1981) (inplicitly equating an inquiry into whether a statute burdening the fundamental rigbt to travel is "overbroad" with a "least restrictive means" test).

105. See Monaghan, supra note 24 , at 14-23.

106. For an example of authority supporting Monaghan, see New York v. Ferber, 458 U.S. 747, $768 \mathrm{n} .21$ (1982) (citing Monaghan for the proposition that "[a] person whose activity may be constitutionally regulated nevertheless may argue that the statute under which he is convicted or regulated is invalid on its face"). The Court's recent decision in United States v. Edge Broadcasting Co., 113 S. Ct. 2696 (1993), supports a corollary of the principle-if not the principle itself-that overbreadth doctrine merely expresses the requirement that laws abridging speech be the least restrictive means of accomplishing a compelling governmental purpose. In Edge Broadcasting, the Court held that where substantive First Amendment doctrine does not require the narrowest possible fit between ends and means, even an as-applied challenge to an apparently overbroad statute may fail. Id. at 2705 (noting that, with respect to commercial speech and tine, place, or manner restrictions, the validity of a law will be judged "by the relation it bears to the general problem of accommodating the policies" which it was designed to further, "not by the extent to which it furthers the Governinent's interest in an individual case"); see also Edenfield v. Fane, $113 \mathrm{~S}$. Ct. 1792, 1805 (1993) (O'Connor, J., dissenting) (arguing that a statute reguIating commercial speech which can survive the test set forth in Central Hudson Gas \& Elec. Corp. v. Public Service Commission, 447 U.S. 557, 566-72 (1980), should be immune to an as-applied challenge).

107. See Fallon, supra note 30 , at 871-75.

108. Id. at 867-75. A nascent version of Fallon's view is set forth in Note, Inseparability in Application of Statutes Impairing Civil Liberties, 61 Harv. L. REv. 1208 (1948). Both the author of the Note and Fallon argue that overbreadth doctrine creates a special rule of nonseverability specific to the First Amendment context. See Fallon, supra note 30, at 898-99; Note, supra, at 1211. In addition, both contend that notwithstanding overbreadth doctrine, a facially overbroad statute regulating expression may be applied prospectively if authoritatively narrowed. See Fallon, supra note 30, at 898-99; Note, supra, at 1211. In this latter respect, they agree with Monaghan.

109. See Fallon, supra note 30, at 873-75. Statements like the following from Village of Schaum- 
historically and consistently interpreted the First Amendment to include a distinctive standing component. ${ }^{110}$ Thus, at least in practice, much of overbreadth doctrine functions in terms of standing.

A complete treatment of First Amendment overbreadth doctrine is beyond the scope of this article. For present purposes, it suffices to note that the doctrine limits courts' application of the Salerno presumption in First Amendment cases. We nay now ask: Does something special about First Amendment rights warrant treating other rights differently in evaluating facial overbreadth challenges, or can we generalize the limits of severability beyond the realm of free expression to other constitutional guarantees?

\section{Overbreadth doctrine and fundamental rights.}

While Fallon recognizes that much of the "argument concerning the proper contours of First Amendment overbreadth doctrine would support a doctrine of equal sweep in cases involving alleged infringements of other fundamental rights," 111 he limits his justification of the doctrine to the First Amendment.112 He does so in part because courts and commentators typically focus on this area, ${ }^{113}$ and in part because the First Amendment is special: "The First Amendment, more even than other constitutional provisions conferring fundamental rights, contributes vitally to the preservation of an open, democratic political regime, at the same time as it secures rights of high miportance to particular individuals."114

Nevertheless, strong theoretical and practical reasons, soine of which the Court has adopted, justify extending the overbreadth doctrine beyond the First Amendment. As an initial matter, the First Amendment is not alone in preserving an open democratic political regime. For example, a state that tolerates

burg v. Citizens for a Better Environment, 444 U.S. 620 (1980), are quite common in the Court's overbreadth cases:

Given a case or controversy, a litigant whose own activities are unprotected may nevertheless challenge a statute by showing that it substantially abridges the First Amendment rights of other parties not before the court. In these First Amendment contexts, the courts are inclined to disregard the normal rule against permitting one whose conduct may validly be prohibited to challenge the proscription as it applies to others because of the possibility that protected specch or associative activities may be inhibited by the overly broad reach of the statute.

Id. at 634 (citations omitted); accord Alexander v. United States, 113 S. Ct. 2766, 2774 (1993) ("The 'overbreadth' doctrine, which is a departure from traditional rules of standing, permits a defendant to make a facial challenge to an overly broad statute restricting speech, even if he himself has engaged in speech that could be regulated under a more narrowly drawn statute.").

110. Fallon, supra note 30 , at $863-64,869-70$. This is true even where the Court has emphasized the narrowness of overbreadth doctrine. For example, in Broadrick v. Oklahoma, 413 U.S. 601 (1973), the Court limited the doctrine by requiring "substantial" overbreadth, at least in cases challenging the speech-restrictive effects of statutes aimed at non-expressive conduct. Id. at 615 . Nonetheless, the majority stated: "[T]he Court has altered its traditional rules of standing to permit-in the First Amendment area-'attacks on overly broad statutes with no requirement that the person making the attack demonstrate that his own conduct could not be regulated by a statute drawn with the requisite narrow specificity." Id. at 612 (quoting Dombrowski v. Pfister, 380 U.S. 479, 486 (1965)).

111. Fallon, supra note 30, at 884 n.192.

112. Id.

113. Id. For the same reason, I focus primarily on facial challenges outside the First Amendment context.

114. Id. 
dissent but disrespects privacy hardly presents a model democratic polity; thus, the Fourth Amendment undoubtedly serves an important democratizing function. And while the First Amendment may have a greater democracy-preserving role than, say, the Eiglith Amendment prohibition on cruel and unusual punishment, so what? The Eighth Amendment engenders a regime in which human beings act compassionately toward all, even the most despised. The Constitution protects citizens not only as political actors but as private beings with interests shielded from the pohitical world. To treat some democracy-preserving constitutional provisions as privileged contravenes the Constitution's own architecture. ${ }^{115}$ Indeed, the "rights of high importance" secured by the First Amendment may, at particular times or for particular people, be less important than those secured by other constitutional provisions, such as the right to bodily integrity.116 Furthermore, the chilling effect that justifies First Amendment overbreadth doctrine may operate against other fundamental rights, and therefore may justify a special overbreadth doctrine for all fundamental rights.

Not all fundamental rights are subject to the kind of chilling effect that justifies the First Amendment's overbreadth doctrine, however. First Amendment rights differ functionally from some other constitutionally protected rights. The right to free speech is a right to engage in primary conduct. It protects agamst government interference with one's action in a realm independent of government functions. While speech may attempt to influence governmental policy, it occurs in an arena that the government does not create. ${ }^{117}$

In contrast, litigation rights have meaning only within the context of an adversarial proceeding. The Bill of Rights guarantees many litigation rights, including, for example, the Fifth Amendment right against self-incrimination. While the free speech right delineates a protected zone into which government may not enter, the right against self-incrimination does not. Indeed, a freestanding zone of non-self-incrimination is meaningless; one can only exercise the right within a zone created and operated by the government, namely criminal prosecution proceedings.

With respect to facial challenges, a primary conduct right differs critically from a litigation right. Because individuals do not exercise litigation rights on their own, but only in the context of a government created adversarial proceed-

115. See Laurence H. Tribe \& Michael C. Dorf, On Reading the Constitution 25-27 (1991) (arguing that no unitary theory of the Constitution can justify favoring one part of the Constitution over another).

116. See Planned Parenthood v. Casey, 112 S. Ct. 2791, 2810 (1992) (describing Roe in part as providing a rule of personal autonomy and bodily integrity). I do not minimize the importance of First Amendment rights from the individual's perspective. My point is simply that for many people the right to speak may seem less important than the right to decide whether and when to form intimate associations or bear intrusive bodily burdens.

117. Private speech on government property raises unique concerns, which the Supreme Court treats under its public forum doctrine. See, e.g., Perry Educ. Ass'n v. Perry Local Educators' Ass'n, 460 U.S. 37, 45-46 (1983) (describing the constitutional significance attaching to the determination that public property constitutes a traditional public forum, a designated forum, or a nonpublic forum). The fact that special rules apply to free speech on government property dennonstrates that the paradigmatic case of free speech involves a purely private realm. 
ing, an overbroad law will not stop an individual not before the court from engaging in protected conduct. As a consequence, litigation riglts are not susceptible to a chilling effect. ${ }^{118}$

To illustrate, consider Salerno. For the moment, let us assume the presumption of severability as a matter of justifiable subconstitutional law.119 Should we nevertheless worry that by forbidding Salerno to challenge the Bail Reform Act's bail criterion-dangerousness to the community-we will chill future detainees from exercising their Eighth Amendment right to reasonable bail? This is not a serious concern. One can only exercise the right to reasonable bail during judicial proceedings. Consequently, if a future detainee wishes to challenge the amount or denial of her bail for resting on a constitutionally illegitimate criterion, the Bail Reform Act does not chill her fronı doing so. We do not need Salerno to stand in for future detainees because they will already be in court where their conduct will receive judicial scrutiny. Apart from Salerno's personal right to be judged by a constitutional rule of law, ${ }^{120}$ his litigation right to reasonable bail does not inherently challenge the presumption of severability.

Litigation rights, however, form only a subset of the category of procedural rights. The term "procedural right" refers generally to a right that can be exercised only in a government-created forun, although not necessarily a courtroom. An example of a nonlitigation procedural right is the fundamental constitutional right to vote. ${ }^{121}$ It is procedural because citizens exercise it only in elections conducted by the government. ${ }^{122}$

Like the right to free speech, some nonlitigation procedural rights may succumb to a chilling effect. Consider again the right to vote. In 1966, in Harper v. Virginia Board of Elections, ${ }^{123}$ the Court held that a state-imposed poll tax unconstitutionally infringes this right. ${ }^{124}$ To illustrate the chilling issue, sup-

118. Barrows v. Jackson, 346 U.S. 249 (1953), could be viewed as an exception to the general principle that litigation rights are not susceptible to the kind of chill which justifies overbreadth analysis. The Barrows Court permitted a defendant in an action seeking damages for noncompliance with a racially restrictive covenant to argue that enforcement would constitute unconstitutional racial discrimination, albeit not against her. The Court, after acknowledging the equivalent of the Yazoo principle, id. at 255-57, distinguished Barrows as "a unique situation in which it is the action of the state court which might result in a denial of constitutional rights and in which it would be difficult if not impossible for the persons whose rights are asserted to present their grievance before any court." Id. at 257. Barrows squares with my general approach to litigation rights, however, because the right at issue differs from most litigation rights: In Barrows, the class of persons to whom the right attaches may never appear before a court. Note also that, although Barrows is an equal protection case, the Court treats it appropriately under the standing rules usually applicable to individual rights cases. Id. at 259-60; see text accompanying notes $65-68$ supra.

119. But see text accompanying notes 218-264 infra (discussing the institutional limits to the presumption of severability).

120. See text accompanying notes 24-54 supra (analyzing the right to be judged by a constitutional rule of law).

121. See, e.g., Kramer v. Union Free Sch. Dist. No. 15, 395 U.S. 621, 626 (1969) ("'S]tatutes distributing the franchise constitute the foundation of our representative society.").

122. Of course, people may vote in all sorts of nongovernmental elections-for corporate directors, union leaders, all-star teams, and so forth-but in doing so they do not exercise the fundamental constitutional right to vote.

123. 383 U.S. 663 (1966).

124. Id. at 666 . The Court decided Harper shortly after the ratification of the Twenty-Fourth 
pose that in 1965 a wealthy Virginia citizen decides that she no longer wishes to pay the poll tax, and attempts to vote without paying it. The state may argue that the tax does not constrain the citizen's rights because she is both able and willing (as demonstrated by her past compliance) to pay the tax. Our wealthy voter might offer an overbreadth defense, however, arguing that the law should permit her to challenge the poll tax because poor persons (or persons of means who would only vote if voting were free or taxed at some lower amount) will not even attempt to vote, and thus, their right to vote will be chilled by the existence of the statute.

The Harper Court effectively decided that this chilling effect indeed justifies a kind of overbreadth analysis, invalidating the poll tax without ever inquiring whether Harper himself could have afforded to pay it. ${ }^{125}$ The Harper court thereby implicitly extended ovcrbreadth analysis to a non-First Amendment, nonlitigation right.

Before generalizing from the voting example, it is revealing to consider three objections to this analysis. First, one might object to the proposition that Harper stands for the extension of overbreadth analysis outside the First Amendment, arguing that the right to vote, as a right to political participation, is a First Amendment right. This argument ultimately fails, as the Court in Harper expressly avoided resting its decision on that ground. ${ }^{126}$ Furthermore, if the right to vote is a First Amendment right, it is at best an "implicit" one, as the petitioner urged in Harper. ${ }^{127}$ While I fully rccogmize the importance and legitimacy of such an implicit right, ${ }^{128}$ virtually all unenumerated rights exist implicitly in some provision of the Bill of Rights, most often in the First Amendment. ${ }^{129}$ Thus the objection - that overbreadth analysis applies to the right to vote only because that right is really a First Amendment right-actually would extend the overbreadth doctrine well beyond its conventional First Amendment context.

A second objection to the voting example might focus on whether our hypothetical reluctant poll tax-payer is in fact bringing an overbreadth challenge, when she has a personal constitutional right to vote without paying a poll tax

Amendment, which expressly prohibits poll taxes in federal elections. See U.S. CoNST. amend. XXIV, $\S 1$.

125. 383 U.S. at 666 ("[A] State violates the Equal Protection Clause of the Fourteenth Amendment whenever it makes the affluence of the voter or payment of any fee an electoral standard.") (emphasis added).

126. Id. at 665 .

127. Id. Note that the First Amendment implicitly includes the right to vote in a different way than the right to speak includes a right not to speak. See Wooley v. Maynard, 430 U.S. 705, 714 (1977) ("[T]he right of freedom of thought ... . includes both the right to speak frecly and the right to refrain from speaking at all."). The latter is merely a specific instance of the former. If the right to vote is implicit in the First Amendment, this is only because it mirrors those rights that receive explicit recognition: Our constitutional regime of self-government cannot function without a right to vote.

128. See TRIBE \& DORF, supra note 115, at 77 (praising Justice Harlan's "process of interpolation and extrapolation" of implicit rights from the express provisions of the Bill of Rights described in Poe $v$. Ullman, 367 U.S. 497, 543 (1961) (Harlan, J., dissenting)).

129. For example, most of the specific rights grouped under the rubric of a constitutional right of privacy can plausibly be derived from the right of association, itself implicit in the First Amendment's Freedom of Assembly Clause. 
whether or not she can afford it. In other words, she complains not merely about being judged by a rule of law that is unconstitutional as applied to others, but unconstitutional as applied to her. This argument, however, ignores the basis for the Court's holding in Harper. The Court found the poll tax unconstitutional as a matter of equal protection ${ }^{130}$ and invalidated the statute because "[v]oter qualifications have no relation to wealth nor to paying or not paying this or any other tax."131 The Constitution does not privilege free voting for its own sake; rather, any system of poll taxation that sufficiently responds to individual circumstances will give state officials too much discretion in making the necessary individual determinations. ${ }^{132}$

The response to the second objection suggests a third: Because the Court sustained the facial challenge in Harper on equal protection grounds, the decision does not establish the validity of overbreadth challenges involving fundamental rights. ${ }^{133}$ This objection, however, ignores the fact that a statute employing a suspect classification or restricting fundamental rights triggers equal protection strict scrutiny. ${ }^{134}$ Indeed, the Harper Court applied equal protection strict scrutiny because the Virginia poll tax interfered with the imdividual's right to vote, an interest the Court termed a "fundamental political right." "135 Equal protection strict scrutiny of statutes that restrict fundamental rights is no different in practice from the strict scrutiny applied in cases challenging restrictions on constitutionally privileged conduct. Both laws which directly restrict constitutionally privileged conduct such as free speech and laws which restrict fundamental rights such as the right to vote must be narrowly tailored to serve a compelling state interest. ${ }^{136}$ In short, Harper can only be explained as an instance of overbreadth analysis outside the narrow context of free speech.

\section{The scope of overbreadth doctrine.}

If overbreadth analysis may be applied to statutes other than those restrict-

130. Harper, 383 U.S. at 666.

131. Id.

132. See Lassiter v. Northampton County Bd. of Elections, 360 U.S. 45, 53-54 (1959) (upholding literacy test for voting, bnt observing that a literacy test which granted a state official unfettered authority to make literacy determinations would be unconstitutional). Professor Tribe observes that the Court decided Lassiter before it began to apply strict scrutiny to voting restrictions, and he donbts that Lassiter's principal holding would "survive the properly herculean demands of strict equal protection review." TRIBE, supra note $30, \S 1315$, at 1093 . Undoubtedly, Lassiter's dictum limiting the state's power to delegate voting qualification decisions to individual officials remains good law. See Lassiter, 360 U.S. at 53.

133. Recall that equal protection underinclusiveness challenges are not subject to the Salerno presumption. See text accompanying notes 63-64 supra.

134. Although Harper suggests that wealth-based classifications are suspect, 383 U.S. at 668 (terming wealth a "traditionally disfavored" classification akin to race), that plainly is not the law, see Harris v. McRae, 448 U.S. 297 (1980) (holding that poverty is not a suspect classification), and the Harper court did not rest its decision on this notion.

135. 383 U.S. at 667 (quoting Yick Wo v. Hopkins, 118 U.S. 356, 370 (1886)).

136. See, e.g., Simon \& Schuster, Inc. v. Members of the N.Y. Crime Victims Bd., 112 S. Ct. 501, 512 (1991) (holding that a New York statute that redirected income earned by criminals was not "narrowly tailored to achieve the State's objective of compensating crime victims from the profits of crime"). 
ing First Amendment rights, what then is the proper scope of overbreadth doctrine? Before answering, note that the list of non-First Amendment, nonlitigation fundamental rights is actually quite short. Other than the First Amendment, none of the express provisions of the Bill of Rights grants an express constitutional privilege to engage in primary conduct. The Supreme Court could conceivably interpret the Second Amendment to privilege gun ownership, but it has not chosen to do so. ${ }^{137}$ Arguably, the Third Amendment protects the homeowner's "fundamental right" to refuse to house troops in peacetime, although the provision is more sensibly read, like the Fourth Amendment, as a himitation upon the means of government intrusion. Similarly, the takings clause of the Fifth Amendment does not privilege private conduct, but prescribes the means by which government may interfere with property ownership, a form of private conduct. The Due Process Clause of the Fifth Amendment protects certain primary conduct from government intrusion, but only as a matter of substantive due process, not as an expressly enumerated right. The remaining provisions of the Fifth through Eighth Amendments concern litigation rights, and the Ninth and Tenth Amendments do not expressly recognize any rights at all.

Because the Bill of Rights, excluding the First Amendment, does not expressly privilege any primary conduct, all other nonlitigation fundamental rights must be unenumerated. ${ }^{138}$ Since the demise of heightened scrutiny for regulation of economic affairs, ${ }^{139}$ nearly all of these rights fall under the general umbrella of a right of "privacy." 140 In short, the Constitution privileges relatively few areas of primary conduct. Thus, with little danger of opening the floodgates, we can say that overbreadth analysis applies only to First Amendment rights and the relatively few unenumerated nonlitigation fundamental rights, such as those stemming from a general right of privacy.

A critic of this conclusion might advocate limiting overbreadth doctrine to the First Amendment based on the unique nature of speech. While rights of privacy protect personal moral decisions from government interference, free speech is an affirmative good. Consider abortion. The Court has held that the state may, in some circumstances, favor childbirth over abortion. ${ }^{141}$ Although more speech may be better than less speech, no parallel assumption suggests that more abortion is better than less abortion. Thus, the critic argues, chilling

137. See, e.g., Lewis v. United States, 445 U.S. $55,65 \mathrm{n} .8$ (1980) (stating that "legislative restrictions on the use of firearms are neither based upon suspect criteria, nor do they trench upon any constitutionally protected liberties").

138. While both the Bill of Rights and Article I, Section 9 of the Constitution place limits on the affirmative powers granted to the federal governnent, these limits do not take the form of privileges to engage in primary conduct.

139. See West Coast Hotel v. Parrish, 300 U.S. 379, 391 (1937) (overruling Adkins v. Children's Hosp., 261 U.S. 525 (1923)) (holding that economic regulation that is "reasonable in relation to its subject" is constitutional).

140. See, e.g., Jed Rubenfeld, The Right of Privacy, 102 HARv. L. REv. 737 (1989) (arguing that the right of privacy delmeates the "legitinuate limits of governmental power").

141. See, e.g., Planned Parenthood v. Casey, 112 S. Ct. 2791, 2825 (1992) (plurality opinion) (upholding Pennsylvania's 24-hour waiting period as a "persuasive neasure[] which favor[s] childbirth over abortion"). 
abortion and other privacy rights poses a less serious constitutional problem than chilling free speech.

This argument fundamentally misconceives the abortion right as well as other privacy rights. It is the right to choose an abortion that warrants constitutional protection, not the right to have one. ${ }^{142}$ The state may attempt to influence a woman's choice, but it may not take that choice away from her. ${ }^{143}$ The Court implicitly recognizes that where privacy rights such as abortion are at stake, more choice (whether of abortion or childbirth) is constitutionally better than less.

Similarly, the free speech right can be characterized as a right to choose whether or not to speak. Indeed, the Court has recognized that the right not to speak is no less prized than the right to speak. ${ }^{144}$ In imvalidating a state law requiring newspapers to print reader replies to newspaper-authored editorials, the Court in Miami Herald Publishing Co. v. Tornillo ${ }^{145}$ agreed with the contention that "the statute [wa]s void on its face because it purport[ed] to regulate the content of a newspaper in violation of the First Amendment." 146 In short, a distinction between a right to choose, such as the right to choose abortion, and a right to exercise a constitutional privilege, such as free speech, does not justify confining overbreadth analysis solely to challenges based on the First Amendment.

Robust overbreadth analysis is particularly appropriate when the law imposes restrictions on the choice to have an abortion. Due to pregnancy's temporary nature, pregnant women may find case-by-case legal relief from abortion rcstrictions particularly impractical. Suppose a woman discovers that she is three months pregnant and wishes to obtain an abortion. If a state law prohibits her from doing so or makes it overly difficult for her to do so, the statute would be invalid as applied to her. However, if we require challenges to overbroad statutes to proceed on a case-by-case basis, she may not obtam a declaratory judgment on its invalidity as applied to her in time to exercise her

142. Id. at 2804 (recognizing "the right of the woman to choose to have an abortion . . . without undue interference from the State") (emphasis added).

143. Id. at 2821 (joint opinion of O'Connor, Kennedy, and Souter, JJ.) (statiug that "a state measure designed to persuade [a woman] to choose childbirth over abortion will be upheld if reasonably related to that goal").

144. See Wooley v. Maynard, 430 U.S. 705 (1977) (holding that the First Amendment precludes New Hampshire from requiring citizens to display the state motto on their license plates); West Va. State Bd. of Educ. v. Barnette, 319 U.S. 624 (1943) (ruling that the state may not compel the flag salute and pledge of allegiance).

145. 418 U.S. 241 (1974).

146. Id. at 247. Although the Court in Miami Herald does not use the term "overbreadth," recourse to that doctrine explains why the Court invalidated the statute on its face rather than as applied. If the Court had applied the Salerno presumption, the Court would have had to uphold the statute on its face because it had severable constitutional applications. For example, a statute that simply requires a newspaper publisher to print a retraction of a defamatory statement is constitutional because the govcrnment has "a pervasive and strong iuterest in preventing and redressing attacks upon reputation." Rosenblatt v. Bair, 383 U.S. 75, 86 (1966). The Florida statute could conceivably be constitutionally applied to compel a publisher to print a retraction that the defamed party had drafted. Yet the Court did not consider this possibility. See Miami Herald, 418 U.S. at 258-59 (Brennan, J., joined by Rehnquist, J., concurring) (stating that the Court's holding with respect to "right of reply" statutes "implies no view upon the constitutionality of retraction statutes"). 
right. Also, she may not wish to pursue what she sees as an uncertain and expensive legal remedy, especially if she lacks legal sophistication or financial resources. Instead, she may travel to a different state to obtain an abortion, engage in self-help, or simply carry the unwanted pregnancy to term. ${ }^{147}$ Thus, requiring that challenges to an overbroad statute prohibiting abortion proceed on a case-by-case basis will chill a woman's right to choose an abortion.

In addition, the fact that an abortion can only be carried out with the aid of a third party-typically a doctor-renders the right to choose an abortion particularly susceptible to a chilling effect. ${ }^{148}$ To exercise her right of choice, both the pregnant woman and the necessary medical personnel must have sufficient courage to disregard the chilling effect of potential state sanctions. ${ }^{149}$ And because the right to choose abortion depends upon the cooperation of medical personnel, overbreadth doctrine offers an effective antidote to the chilling effect. As I have noted before, ${ }^{150}$ overbreadth doctrine works best when individuals who feel the chill of an overbroad statute can depend on an institution with greater financial and legal resources-such as a hospital or abortion chinic-to challenge the statute on its face.

\section{The Court's privacy jurisprudence and the Salerno principle.}

I have argued that the chilling effect justifies First Amendment overbreadth doctrine as well as overbreadth doctrine for other fundamental rights. I have also argued that the Court has adopted overbreadth analysis to scrutinize statutes that restrict fundamental rights in a manner that raises questions of equal protection. But what is the law regarding facial challenges to statutes burdening non-First Amendment rights? Does the account I gave merely prescribe what the law should be, or does it actually describe the law as it stands?

I return, then, to the question 1 posed at the beginning of the article: Is Justice Scalia correct when he states in his dissent from denial of certiorari in

147. In Barnes v. Moore, 970 F.2d 12 (5th Cir.), cert, denied, 113 S. Ct. 656 (1992), the Fifth Circuit dismissed a facial challenge to a Mississippi statute that requires women to wait 24 hours between seeing a doctor and obtaining an abortion. After Mississippi began enforcing this statute, the number of abortions performed in the state fell by roughly half. Linda Greenhouse, Justices Decline to Hear Abortion Case, N.Y. Tmes, Dec. 8, 1992, at A22; Mark Mayfield, 24-Hour Wait Biggest Part of "Obstacle Course," USA TODAY, Jan. 22, 1993, at 5A. While part of the decline is no doubt due to women travelling to other states, at least some women who previously would have had abortions are simply having babies. See id. If a putatively constitutional limitation can have such a chilling effect, an even more burdensome law would certainly chill the abortion right.

148. Even RU486, the so-called "abortion pill," must be taken under the direction of a doctor. Philip J. Hilts, Door May Be Open for Abortion Pill to Be Sold in U.S., N.Y. TMEs, Feb. 25, 1993, at A1.

149. Overbreadth and jus tertii doctrine, while distinguishable, are closely connected. See BATOR ET AL., supra note 55, at 169-70 (noting distinctions between third-party claims and overbreadth challenges). Emphasizing jus tertii doctrine, the Court has permitted doctors to challenge abortion statutes. See Planned Parenthood v. Danforth, 428 U.S. 52, 62 (1976) (holding that physicians have standing to challenge abortion statutes because such statutes pose a "direct threat of personal detriment"); Doe v. Bolton, 410 U.S. 179, 188 (1973) (stating that physicians need not "be required to await and undergo a criminal prosecution as the sole means of seeking relief"); $c f$. Griswold v. Connecticut, 381 U.S. 479, 481 (1965) (ruling that physicians may "raise the constitutional rights of the married people with whom they have a professional relationship" as a defense to criminal prosecution for providing contraception).

150. See note 98 supra. 
Ada v. Guam Society of Obstetricians and Gynecologists 151 that the Court's abortion decisions (and by implication, all of its privacy decisions) are generally consistent with the Salerno standard for judging facial challenges? The answer is an unequivocal no.

As an initial matter, the Court often uses overbreadth analysis in fundamental rights cases involving rights other than abortion, ${ }^{152}$ as well as in cases involving abortion regulations. ${ }^{153}$ As Justice Scalia himself acknowledges in Ada, Roe v. Wade ${ }^{154}$ exemplifies overbreadth analysis. ${ }^{155}$ After setting forth the standard deemed appropriate for measuring abortion statutes, the Roe Court employed an analysis indistinguishable from First Amendment overbreadth doctrine:

Measured against these standards, [the Texas statute], in restricting legal abortions to those "procured or attempted by medical advice for the purpose of saving the life of the mother," sweeps too broadly. The statute makes no distinction between abortions performed early in pregnancy and those performed later, and it limits to a single reason, "saving" the mother's life, the legal justification for the procedure. The statute, therefore, cannot survive the constitutional attack made upon it here. ${ }^{156}$

Roe hardly presents an anomalous approach, despite Justice Scalia's claim to the contrary in Ada.157 As Professor Fallon has observed, "virtually all of the abortion cases reaching the Supreme Court since Roe v. Wade ... have involved facial attacks on state statutes, and the Court, whether accepting or rejecting the challenges on the merits, has typically accepted this framing of the question presented."158

To support his clain that the Salerno standard applies in abortion cases,

151. 113 S. Ct. 633, 633-34 (1992) (Scalia, J., dissenting), denying cert. to 962 F.2d 1366 (9th Cir. 1992).

152. See, e.g., Carey v. Population Servs. Int'1, 431 U.S. 678 (1977) (facially invalidating a New York law prohibiting distribution of contraceptives by persons other than licensed pharmacists as an infringement of the right to make procreative decisions); Aptheker v. Secretary of State, 378 U.S. 500, 515 (1964) (facially invalidating a provision of the Subversive Activities Act of 1950 which prohibited communist party members from obtaining a passport as "indiscriminately cast and overly broad").

153. Although the joint opinion of Justices O'Connor, Kennedy, and Souter in the Court's most recent abortion decision, Planned Parenthood v. Casey, 112 S. Ct. 2791 (1992), nowhere expressly refers to abortion as a "fundamental right," the Court's repeated statements reaffirming the essential holding of Roe v. Wade plainly show that a woman's right to choose to have an abortion retains a preferred status under the Constitution. See Casey, $112 \mathrm{~S}$. Ct. at 2804; id. at 2816, 2817 (joint opinion). We may best understand the plurality's "undue burden" standard not as an alternative to strict scrutiny, but as an elaboration of what strict scrutiny allows in the abortion context.

154. 410 U.S. 113 (1973).

155. $113 \mathrm{~S}$. Ct. at 634 (Scalia, J., dissenting) (stating that the Court "seemingly applied an 'overbreadth' approach").

156. 410 U.S. at 164 (emphasis added).

157. $113 \mathrm{~S}$. Ct. at 634.

158. Fallon, supra note 30 , at 859 n.29 (citation omitted); see Ohio v. Akron Ctr. for Reprod. Health, 110 S. Ct. 2972 (1990); Hodgson v. Minnesota, 110 S. Ct. 2926 (1990); Webster v. Reprod. Health Servs., 492 U.S. 490 (1989); Thornburgh v. American College of Obstetricians \& Gynecologists, 476 U.S. 747 (1986), overruled on other grounds, Planned Parenthood v. Casey, 112 S. Ct. 2791 (1992); Planned Parenthood v. Danforth, 428 U.S. 52, 8184 (1976). The Court arguably applied the Salemo approach in H.L. v. Matheson, 450 U.S. 398, 405-06 (1981), but an alternative explanation exists. See note 163 infra. 
Justice Scalia in his Ada dissent cites Justice O'Connor's concurrence in Webster v. Reproductive Health Services. ${ }^{159}$ Even on the assumption that a singleJustice opinion could establish such a proposition in the face of majority opinions to the contrary, Justice O'Connor's Webster concurrence simply does not support the weight Justice Scalia would have it bear. While Justice O'Connor cited Salerno to explain her vote to uphold Missouri's ban on the performance of abortions in publicly funded facihties, ${ }^{160}$ she did so only to support a proposition much narrower than the Salerno rule. In Webster, petitioners argued that the Missouri statute banning funding was invalid because the state could enforce it "against private hospitals using public water and sewage lines, or against private hospitals leasing state-owned equipment or state land."161 Justice O'Connor rejected the facial attack based on what she deemed "conceivable applications of the ban."162 Her concurrence hardly invoked the Salerno presuinption in its full draconian spirit. Rather, her finding rested on a basic canon of constitutional adjudication: that, where possible, statutes should be construed so as to be constitutional. ${ }^{163}$ Virtually all statutes have some "conceivable" unconstitutional applications, but even the most adamant proponent of overbreadth doctrine would not suggest that these conceivable apphications alone provide a sufficient basis for a statute's facial invalidation. 164

Should doubt persist, Justice Kennedy's opinion for the Court in Ohio $v$. Akron Center for Reproductive Health ${ }^{165}$ made clear that Justice O'Connor's

\footnotetext{
159. 492 U.S. at 522-31 (O'Connor, J., concurring in part and concurring in the judgment).

160 . Id. at 524 .

161. Id. at 523 .

162. Id.

163. Justice O'Connor stated:

There are ... cases in which the Court has held that even though a party will suffer a direct substantial injury from apphication of a statute, he cannot challenge its constitutionality unless he can show that he is within the class whose constitutional rights are allegedly infringed. One reason for this ruling is that the state court, when actually faced with the question, might narrowly construe the statute to obliterate the objectionable feature, or it might declare the unconstitutional provisions separable.
}

Barrows v. Jackson, 346 U.S. 249, 256 (1953) (citations omitted). This principle could explain the Court's approach in H.L. v. Matheson, 450 U.S. 398 (1981). In that case, the Court refused to invalidate a Utah statute requiring parental notification of a minor's decision to obtain an abortion. The appellant challenged the statute as overbroad on its face, contending that it would apply to a mature and "emancipated" minor (i.e., a minor no longer dependent on his or her parents). Following the course taken by the state courts, the Supreme Court found that the appellant had not offered evidence that she was "mature" or "emancipated," and upheld the statute on the ground that the appellant, as an "unemancipated minor," lacked standing to make an overbreadth argument. However, the Court may have been uncertain whether the state court would narrowly construe the statute so as "to exempt demonstrably mature minors," and hence may have been unwilling to do so itself. Id. at 406. Thus, in accordance with the Barrows reasoning, the Court may have denied standing to the appellant in Matheson in part because it did not wish to decide whether the state court would choose to separate the unconstitutional provision from the rest of the statute in order to remedy its flaw.

164. Federalism presents an additional reason to reject facial invalidity. If a state statute does not plainly encompass within its scope the allegedly invalid applications, a federal court may assume that the state's highest court will, in an appropriate case, construe the statute as inapplicable. See Fallon, supra note 30, at 893 ("A federal court should generally not hold a state statute overbroad if a constitutionally adequate narrowing construction suggests itself." (citing Erznoznik v. City of Jachsonville, 422 U.S. 205, 216 (1975); Dombrowski v. Pfister, 380 U.S. 479, 497 (1965))); text accompanying notes 229236 infra.

165. 110 S. Ct. 2972 (1990). 
invocation of Salerno in her Webster concurrence rested on principles of statutory construction. In the portion of his opinion that Justice O'Connor joined, Justice Kennedy cited her Webster concurrence, including the Salerno standard, for the proposition that a court should not invalidate a state statute "on a facial challenge based upon a worst-case analysis that may never occur." 166 The discussion around this conclusion inakes clear that the "worst-case analysis" refers to an interpretation of the statutory provision that leads to an unconstitutional result. ${ }^{167}$ The Court refused to consider what it termed a "dubious" interpretation of state law by the lower federal courts a sufficient basis for facial invalidation, and relied on one of its staple rules that " " $[\mathrm{w}]$ here fairly possible, courts should construe a statute to avoid a danger of unconstitutionality." "168 Far froin showing that fundamental rights cases differ from First Amendment overbreadth cases, the method of analysis in Justice O'Connor's Webster concurrence and the opinion of the Court in Akron Center closely followed First Amendment overbreadth doctrine.

The Court used the same principle of statutory construction in a First Amendinent case, Burson v. Freeman. ${ }^{169}$ In Burson, the Court considered a facial challenge to a Tennessee statute forbiddiug citizens from soliciting votes and displaying or distributing campaign materials within 100 feet of a polling place on election day. In upholding the statute on the ground that it satisfied strict scrutiny, the plurality rejected the arguinent that the statute should be invalidated because the state could conceivably apply it to an individual driving by a polling place in an automobile with a campaign buinper sticker. ${ }^{170}$ The plurality explained:

[T] hese arguments are "as applied" challenges that should be made by an individual prosecuted for such conduct. If successful, these challenges would call for a limiting construction rather than a facial invalidation. In the absence of any factual record to support respondent's contention that the statute has been applied to reach such circumstances, we do not entertain the challenges in this case. ${ }^{171}$

Thus, while fundamental rights overbreadth doctrine inay be as sweeping as First Amendment overbreadth doctrine, it does not cast a wider net. This stands to reason. Because the same principles justify both fundamental rights overbreadth doctrine and First Amendinent overbreadth doctrine, the two approaches should contain the same linnitations, such as the preference for constitutional avoidance through statutory construction illustrated in Akron and Burson.

Another First Amendinent case, Broadrick v. Oklahoma, ${ }^{172}$ establishes a closely related limitation applicable in both areas. In Broadrick, the Court nar-

166. Id. at 2981.

167. Id. at $2980-81$.

168. Id. at 2980 (quoting Planned Parenthood Ass'n v. Ashcroft, 462 U.S. 476, 493 (1983)).

169. 112 S. Ct. 1846 (1992).

170. Id. at 1857 n.13 (plurality opinion).

171. Id.

172. 413 U.S. 601 (1973). 
rowed the scope of First Amendment overbreadth doctrine by adding a requirement that, at least when a statute targets conduct as opposed to pure speech, "the overbreadth of a statute must not only be real, but substantial as well, judged in relation to the statute's plainly legitimate sweep."173

Although the Court leaves unclear what constitutes "substantial overbreadth," the purpose of the limitation is apparent. An unchecked overbreadth doctrine would invalidate entire statutes otherwise easily "cured" through narrow interpretation. A narrowed statute is better than a nonexistent one; its remaining parts carry out legitimate governmental interests, and because the law is not directed at protected activity, it is unlikely to chill protected activity. Even if some chilling effects result, the substantiality requirement reflects a judgment that the chilling effects must reach a threshold level before justifying invalidation of an entire law.

To understand how the substantial overbreadth requirement operates in the context of fundamental rights overbreadth doctrine, consider a hypothetical state statute titled "Second Opinion Act," requiring all persons to obtain the advice of two doctors before undergoing any nonemergency surgical procedure. Assume the Act's purpose is to decrease the number of unnecessary operations, and thus promote both health and the containment of medical costs. Now suppose a plastic surgeon who specializes in elective procedures challenges the law on overbreadth grounds, arguing that the Act as applied to abortions constitutes an undue burden. In applying Broadrick's substantial overbreadth limitation, a court would deny the plastic surgeon's challenge. Because the law does not target abortion or some other fundamental right, the surgeon must show its substantial overbreadth; yet, the law does not operate unconstitutionally as applied to the vast majority of nonemergency surgical procedures.

In its most recent abortion decision, Planned Parenthood v. Casey, ${ }^{174}$ the Court used similar reasoning in upholding a Pennsylvania law's abortion restrictions against a facial attack. In Casey, the Court first determined that Pennsylvania's 24-hour waiting period requirement served a valid purpose that did not target the right at stake, and was therefore not unconstitutional on that ground. ${ }^{175}$ The Court then addressed whether the 24-hour waiting period nonetheless places an unconstitutional incidental burden on the right to choose to have an abortion. ${ }^{176}$ Based on the factual record before the Court and the fact

173. Id. at 615 (emphasis added).

174. 112 S. Ct. 2791 (1992).

175. See id. at 2825 ("The idea that important decisions will be more informed and deliberate if they follow some period of reflection does not strike us as unreasonable, particularly where the statute directs that important information become part of the background of the decision."); see also id. at 2819 ("The fact that a law which serves a valid purpose, one not designed to strike at the right itself, has the incidental effect of making it more difficult or more expensive to procure an abortion cannot be enough to invalidate it.").

176. Id. at 2825. The plurality's assumption that the 24-hour waiting period places an incidental rather than a direct burden on the abortion right is a dubious one, as even the dissenters noted. See id. at 2878 (Scalia, J., joined by Rehnquist, C.J., White, J., and Thomas, J., concurring in the judgment in part and dissenting in part) ("Pennsylvania has consciously and directly regulated conduct that our cases have held is constitutionally protected."). Pennsylvania did not, after all, require a 24 -hour waiting period for all or even many medical procedures, but only for abortion. Moreover, the law's title, the 
that the attack on the law was facial, the plurality held that the district court's finding that the waiting period would have a "particularly burdeusome" effect on some women-especially rural and poor women - did not constitute a "substantial" obstacle. 177

The Casey plurality thus applied "substantial overbreadth" analysis. The Court first determined that the waiting period requirement targeted unprotected activity. It then asked whether the potentially invalid applications were substantial when compared to the valid applications. While the Court's use of the substantial overbreadth doctrine meant that a potentially invalid application would be insufficient to render a law unconstitutional on its face, the plurality's focus on "the record before"178 it implies that the mere existence of some potentially valid applications would not save an otherwise substantially overbroad statute.

The Court's substantial overbreadth analysis contradicts the Salerno principle. Under Salerno, no factual showing of unconstitutional applications can invalidate a statute that has any constitutional applications. The Casey plurality, by focusing on the record before it, clearly implies that even though they require substantial overbreadth, they will invalidate significantly nore legislation under that standard than they would under Salerno. Consider the husband notification provision of the Pennsylvania statute, which the Court struck down as unconstitutional. The Court states that "in a large fraction of the cases in which [the husband notification provision] is relevant, it will operate as a substantial obstacle to a woman's choice to undergo an abortion. It is an undue burden, and therefore invalid." 179 Because the provision operates unconstitutionally in "a large fraction" of cases, the plurality invalidates it on its face, notwithstanding its constitutional operation in other circumstances. ${ }^{180}$ Under Salerno, this provision would withstand a facial attack.

In fact, the Court has been applying overbreadth analysis in substantive due process cases for quite some time, albeit without expressly stating as much. Justice Scalia's contention to the contrary in his Ada dissent plainly misinterprets the Court's opinions. ${ }^{181}$

\footnotetext{
"Pennsylvania Abortion Control Act," strongly suggests that the restrictions, including the 24-hour waiting period, in fact target the abortion right itself. Nevertheless, these criticisms relate to the plurality's understanding of the underlying substantive right and limits upon it; if we accept the assumption that the 24-hour waiting period imposes a mere incidental burden, then the plurality's application of overbreadth doctrine parallels the First Amendment doctrine of substantial overbreadth.. See text accompanying notes 177-181 infra.
}

177. Casey, 112 S. Ct. at 2825 .

178. Id.

179. Id. at 2830.

180. In upholding Mississippi's 24-hour waiting period, the Fifth Circuit acknowledged the inconsistency between the Casey Court's invalidation of Pennsylvania's husband notification provision and the Salerno standard. The Fifth Circuit, however, ruled that Casey did not overtum "Iongstanding Supreme Court precedent goveming challenges to the facial constitutionality of statutes." Barnes v. Moore, 970 F.2d 12, 14 n.2 (5th Cir. 1992). Justice O'Connor, joined by Justice Souter, mdicated in Fargo Women's Health Org. v. Schafer, 113 S. Ct. 1668 (1993), that this was no oversight, stating that in Casey, the Court "did not require petitioners to show that the provision would be invalid in all circumstances." Id. at 1668-69 (concurring opinion).

181. It should be noted that one substantive due process case, Bowers v. Hardwick, 478 U.S. 186 


\section{The basis of overbreadth doctrine.}

I have shown that in fundamental rights cases, the Court apphies overbreadth analysis. To complete the discussion of the doctrine, I explore why the Court applies it. Does the Constitution require this, or is it judge-made? In more practical terms, could Congress or the Court modify First Amendment/ fundamental rights overbreadth doctrine as a matter of statutory or common law? In short, what sort of an animal is overbreadth doctrine?

As discussed earher, ${ }^{182}$ the overbreadth doctrine has two components: (1) every person's right to be judged by a constitutionally valid law, which the discussion of Marbury v. Madison makes clear is rooted in the Constitution;183 and (2) the desire to avoid the chilhing effect of overbroad statutes, which some refer to as "prophylaxis." If a subconstitutional part of overbreadth doctrine exists, it must he in its prophylactic component.

Professor Fallon argues that the Constitution requires some form of overbreadth doctrine in order to protect against "judicial sanction and from chill arising from the fear of being sued or prosecuted." 184 He goes on to state, however, that the Constitution requires no specific version of overbreadth doctrine. ${ }^{185}$ In other words, according to Fallon, the prophylactic component of the doctrine is judge-made; 186 the Court or Congress would be free to substitute some other set of overbreadth rules for the set he proposes. ${ }^{187}$

Fallon correctly recognizes a constitutional element to prophylaxis. Indeed, much of the justification for First Amendment rights is prophylactic. Justice Holmes demonstrated this in his classic answer to the question of why the advocacy of foolishness, or even evil, deserves protection.

If you have no doubt of your premises or your power and want a certain result with all your heart you naturally express your wishes in law and sweep away all opposition. ... But when men have realized that time has upset many fighting faiths, they may come to believe even more than they believe the very foundations of their own conduct that the ultimate good desired is better

(1986), quite clearly does not employ overbreadth analysis. The Georgia statute at issue in Hardwick applied to both homosexual and heterosexual sodomy; yet, as Justice Blackmun noted in dissent, the Court chose to treat the "case as an 'as applied' challenge," id. at 201, ignoring the fact that the statute would have a chilling effect on heterosexuals. Id. at 188 n.2. I cannot reconcile Hardwick's approach to the facial/as-applied question with the Court's approach in other fundamental rights cases, but then, neither can I reconcile Hardwick's principal holding with most modern substantive due process cases. See TRIBE \& DoRF, supra note 115, at 117 (describing the holding of Hardwick as "egregiously wrong").

182. See text accompanying notes $96-103$ supra.

183. See text accompanying notes 39-48 supra.

184. Fallon, supra note 30 , at 868 n.94.

185. Id.

186. Id. at $875-80$. Fallon offers one constitutional caveat to his blanket statement: Courts may not use a case-by-case approach if doing so violates a defendant's right to fair warning. Id. at 877-78 (discussing Dombrowski v. Pfister, 380 U.S. 479, 491 n.7 (1965)). As Fallon notes, however, the requirement of fair warning is not unique to First Amendment (or general fundamental rights) overbreadth, but applies to all instances of case-by-case narrowing. Id. at 878 .

187. Id. at 877-907. Fallon's doctrine includes different rules for the Supreme Court and lower federal courts. He also argues that the timing of an overbreadth ruling is significant, as is the nature of the constitutional challenge. 
reached by free trade in ideas . . . ${ }^{188}$

Because we do not trust ourselves (or our judges) to distinguish between good and bad ideas, we take the prophylactic measure of protecting all ideas. Of course, this justification for First Amendment rights in no way diminishes the constitutional status of those rights. On the contrary, their constitutional status requires the courts to employ overbreadth doctrine. ${ }^{189}$

Since both components of the overbreadth doctrine are constitutionally based, the Constitution itself proscribes the use of the Salerno presumption. A typical overbreadth challenge illustrates this point. A plaintiff claims she cannot be judged by a statute because, regardless of the status of her own conduct, the statute reaches a substantial amount of constitutionally protected conduct. She claims that as long as the statute remains on the books unnarrowed, it will chill the exercise of First Amendment or other fundamental rights. Furthermore, she claims that the statute's chill itself comprises a significant aspect of its unconstitutional operation. To understand why applying the presumption of severability in this context would be constitutionally impermissible, we must distinguish between actually severing a statute's unconstitutional portions or applications and presuming severability.

If the court actually declares invalid and severs the unconstitutional portions or applications of the challenged statute, the plaintiff has no constitutional complaint. The court will now judge her by a constitutionally adequate rule of law-the statute minus its unconstitutional portions and apphications. In contrast, when a court presumes severability, it actually upholds the law. In effect, it tells the plaintiff, "don't worry about any potential unconstitutional apphications of the statute; we'll deal with those when they arise." Whatever general shortcomings the presumption approach has, ${ }^{190}$ the presence of a chilling effect adds a fatal fiaw. The court cannot tell our plaintiff, unlike a hitigant who challenges an overbroad statute with no chilling effect, that the rights of third parties can be vindicated if and when they are violated. Under the presumption of severability, third parties whose rights are chilled will not appear before the court (and, at least in federal court, might not present a case or controversy even if they did appear). Thus, when the court considers the overbreadth challenge, applying the Salerno presumption entails judging the litigant by an unconstitutional rule of law-unconstitutional because, at least for the time being, it chills the behavior of third parties. For this reason, much of the First Amend-

188. Abrams v. United States, 250 U.S. 616, 630 (1919) (Holmes, J., joined by Brandeis, J., dissenting).

189. Consider also the Fourth Amendment. If the police search a person's home without probable cause, whether or not the police discover evidence of criminal activity, they violate the person's Fourth Amendment rights. We justify the prohibition not because individuals have a right to engage in criminal conduct in their home, but rather based on a balancing of values reflected in the Fourth Amendment. We consider privacy sufficiently important that we forbid the police to peer into a person's home unless they have probable cause to believe that the individual has sacrificed her right to privacy by engaging im criminal conduct. Thus, the Fourth Amendment protects us in a world of imperfect information. If criminals did not have Fourth Amendment rights, the privacy of the innocent would be $\mathrm{m}$ jeopardy as well. The right is justified as a matter of prophylaxis, but once justified, it becomes a full-fledged constitutional right.

190. See Part III infra. 
ment/fundamental rights overbreadth doctrine precludes the use of the Salerno presumption as a matter of constitutional, not subconstitutional law.

\section{Impermissible Purpose and the Salerno Principle}

In a variety of contexts, the Court has held that statutes with an unconstitutional purpose may be found facially invalid. ${ }^{191}$ This rule coinprises another substantive constitutional norm that precludes use of the Salerno presumption. If a statute serves an impermissible purpose, courts cannot save it by severing its unconstitutional applications. ${ }^{192}$ The invalid legislative purpose pervades all of the provision's applications. Indeed, the idea of severing an application of law froin its purpose appears nonsensical.

Still, one might argue that the Salerno principle is technically appropriate in cases involving an allegedly unconstitutional statutory purpose because, if the illegitinate purpose pervades all applications, then "no set of circumstances" exists under which the statute can be validly enforced. But the Salerno principle focuses on the application of the statute, not its purpose, and thus provides no guidance when a court examines the constitutionality of a statute's goal. Ignoring the Salerno principle presents the sounder course when considering questions of illegitimate purpose.

The First Amendment's Establishment Clause illustrates this point. Under Lemon v. Kurtzman, ${ }^{193}$ a law violates the establishment clause if (1) it lacks "a secular legislative purpose," or (2) its primiary effect is to advance or inhibit religion, or (3) it results in "excessive government entanglement with religion."194 Although individual Justices have questioned the Lemon test's continued vitality, ${ }^{195}$ most agree that a statute with no secular purpose still violates the Establishment Clause. ${ }^{196}$

The Court applied the purpose prong of Lemon in Edwards v. Aguillard ${ }^{197}$ to strike down a state statute on its face. In Edwards, the Court considered the constitutionality of Louisiana's "Balanced Treatment for Creation-Science and Evolution-Science in Public School Instruction Act." While the law did not

191. See text accompanying notes 193-200 infra.

192. Of course, if the purpose of one provision of a statute is invalid, but other provisions serve valid legislative purposes, then the invalid portion may be severed subject only to conventional severability constraints. The text therefore discusses only application severability, not clause severability.

193. 403 U.S. 602 (1971).

194. Id. at 612-13.

195. See County of Allegheny v. ACLU, 492 U.S. 573, 655 (1989) (Kennedy, J., joined by Rehnquist, C.J., White, J., and Scalia, J., concurring in part and dissenting in part) (remaining within the Lemon framework "for present purposes," but noting prior criticisun of the framework); Aguilar v. Felton, 473 U.S. 402, 426-30 (1985) (O'Connor, J., dissenting); Wallace v. Jaffree, 472 U.S. 38, 108-13 (1985) (Rehnquist, J., dissenting); Roemer v. Board of Pub. Works, 426 U.S. 736, 768-69 (1976) (White, J., concurring).

196. To date, only two of the Justices who have publicly called for the abandonment of Lemon have objected to the purpose prong. See Edwards v. Aguillard, 482 U.S. 578, 613 (1987) (Scalia, J., joimed by Rehnquist, C.J., dissenting). Moreover, although sharply divided on the outcome of the case, all members of the Court applied the purpose prong of Lemon in Bowen v. Kendrick, 487 U.S. 589 (1988).

197. 482 U.S. at 578. 
mandate the teaching of either evolution or "creation science,"198 it did require that if one theory were taught, the other receive equal treatment. 199 The Court rejected the state's argument that the law served the secular purpose of promoting academic freedom. The Court found that the law's actual purpose was to narrow, rather than expand, the science curriculum, ${ }^{200}$ and thereby to endorse a religious view. The Court did not inquire further whether the statute did so in all of its applications. Edwards firmly establishes that the Salerno presunption of severability does not apply to facial challenges to statutes with an unconstitutional purpose.

One might take this reasoning a step further and argue, as have four Justices, that the effect prong of the Lemon test is also inconsistent with the Salerno approach. In Bowen v. Kendrick, ${ }^{201}$ the Court upheld the Adolescent Family Life Act, whicl authorizes federal grants to religious institutions for services and researcl relating to premarital adolescent sexual relations and pregnancy. In dissent, Justice Blackmun agreed with what he deemed the majority's assertion that in cases involving facial challenges on Establishment Clause grounds, the Court rejects the rigid Salerno test and instead assesses the constitutionality of the enactment according to the three-pronged Lemon test. ${ }^{202}$ Justice Blackmun argued against use of the Salerno principle to permit a statute to survive a facial challenge because it could be validly applied under a liypothetical circumstance, noting this would utterly vitiate the "primary effect" prong of Lemon. ${ }^{203}$ The Salerno formulation requires that the statute's sole effect be to advance religion for a court to find it facially invalid. The Lemon test, by focusing on primary effect, allows a court to render a statute mvalid though it may have some secular effect. ${ }^{204}$

Justice Blackmun's argument that applying Salerno vitiates the Lemon test, while persuasive, has not been adopted by a majority of the Court. In other words, the Kendrick dissenters' assertion that even the majority recognized the inapplicability of Salerno in Establishment Clause cases may have been an overstatement. True, the Court rejected the government's request that it apply the Salerno presumption, ${ }^{205}$ but in so doing it stated: "As in previous cases involving facial challenges on Establishment Clause grounds, ... we assess the constitutionality of an enactment by reference to the [Lemon test]."206 Whereas the dissent reads the Court's reference to the Lemon test as a repudiation of the Salerno presumption, the Court may have meant only that the Lemon

198. The Act defined creation science as "the scientific evidences for [creation] and inferences from those scientific evidences.'" Id. at 581 (quoting LA. REv. STAT. ANN. \$ 17:286.3(2)). While this defimition is singularly unhelpful, the Court inferred from the Act's legislative history that the term "einbodies the religious belief that a supernatural creator was responsible for the creation of humankind." Id. at 592.

199. Id. at 581 .

200. Id. at 586-87.

201. 487 U.S. 589 (1988).

202. Id. at 627 n.1 (Blackmun, J., dissenting).

203. Id.

204. Id. at $627 \mathrm{n} .1$ (citing id. at 602).

205. Id. at 602 (opirion of the Court).

206. Id. (citations omitted). 
test supplies the substantive rule of law, regardless of the standard applicable to facial challenges. ${ }^{207}$ Thus, while cases like Kendrick and Edwards v. Aguillard exemplify the proposition that the Salerno presumption does not apply to Lemon's purpose prong (or other substantive tests which turn on purpose), 208 whether it applies to the effect prong remains an open question.

\section{Concluding Remarks on Constitutional Barriers to the Salerno Presumption of Severability}

The foregoing illustrations do not exhaustively catalogue the substantive constitutional norms that constrain a court's power to apply the Salerno presumption of severability. One might interpret these Supreme Court decisions to mean that the application of the presumption would undermine other constitutional provisions. Indeed, because so many diverse principles of constitutional law are known to be incompatible with the presumption, one may question its applicability to any individual case. ${ }^{209}$

For example, the Court has rejected the severability of statutes when determining whether due process permits a court to exercise personal jurisdiction over an absent defendant. In both Wuchter $v$. Pizzutti ${ }^{210}$ and Shaffer $v$. Heit$n e r,{ }^{211}$ the Court ignored whether or not the particular circumstances of the defendant justified the exercise of personal jurisdiction by the trial court, hold-

207. Chief Justice Rehnquist, writing for the majority in Kendrick, accepted the distinction between facial and as-applied challenges in the Establishment Clause context, although he acknowledged that the Court had never before delineated the consequences of this distinction. Id. at 600-02. This said, Chief Justice Rehnquist took a novel approach to the distinction, treating the factual record developed in the lower courts as relevant only to the as-applied portion of the constitutional challenge. Id. at 618-22. This treatment prompted Justice Blackmun to observe that whether a challenge is denominated "facial" or "as-applied," "the Court should not blind itself to the facts revealed by the undisputed record." Id. at 628 (Blackmun, J., dissenting).

208. Id. at 627 n.1. I should acknowledge that many statutes serve inultiple purposes. For instance, incarceration of criminals serves the purposes of retribution, isolation, deterrence, and perhaps rehabilitation. The constitutionality of a statute that serves both valid and invalid purposes presents a question of substantive constitutional law. However, once a statute meets the test for having an invalid purpose-whether that test focuses on the exclusive purpose, primary purpose, or merely any purposethe invalid purpose pervades all of the statute's applications. In the Establishment Clause area, the Court has utilized different formulae to express the requirements of Lemon's purpose prong. For an argument that the test properly focuses on the law's primary purpose, see Cammack v. Waihee, $932 \mathrm{~F} .2 \mathrm{~d}$ $765,782-83$ (9th Cir. 1991) (D.W. Nelson, J., dissenting) (maintaining that Hawaii's official Good Friday holiday did violate the Establishment Clause). See also Cammack v. Waihee, 944 F.2d 466, 46971 (9th Cir. 1991) (Reinhardt, J., dissenting from denial of rehearing en banc).

Provisions of law may also serve different purposes when applied to different circumstances. For example, suppose that the ingestion of a certain food preservative causes ovarian cancer in women and prostate caneer in men. Congress might prohibit the sale of the preservative in interstate commerce for two separate purposes: to prevent ovarian cancer in women and to prevent prostate cancer in men. Such a statute, which serves entirely distinct purposes depending on the situation, might be an example of a provision of law where one illegitimate purpose might not pervade all of its other applications. I presume that such statutes are sufficiently uncommon as to leave intact the general principle that the $\mathrm{Sa}$ lemo approach does not apply to cases involving an illegitimate purpose. In any event, we might more properly think of such a statute as two distinct statutes codified in one shorthand provision of law.

209. Contracting the Salerno presumption of severability to a smaller domain would exemplify what Professor Tribe and I elsewhere have termed "exception-barring" and would suffer from the flaws inherent in that mode of legal analysis. See TRIBE \& DORF, supra note 115, at 90-95.

210. 276 U.S. 13 (1928).

211. 433 U.S. 186 (1977). 
ing instead that the statute under which service was made proved defective.212 One might dismiss these cases as instances of the Court simply ignoring the Salerno presumption, ${ }^{213}$ but that would disregard the underlymg substantive doctrine that justifies the Court's departure from the presumption. ${ }^{214}$ More importantly, these cases show that substantive constitutional law constrains severabihty doctrine in numerous ways, even in peripheral areas of constitutional law such as personal jurisdiction. ${ }^{215}$

At the very least, this discussion demonstrates the gross overstatement of the Court's pronouncement in Salerno that it has "not recognized an 'overbreadth' doctrine outside the limited context of the First Amendment."216 Rather, the Court has enforced numerous substantive constitutional norms by presuming that unconstitutional applications cannot be severed from constitutional ones. The Court's failure to expressly recognize that in so doing it has permitted facial challenges outside the First Amendment context does not di-

212. In Wuchter v. Pizzutti, 276 U.S. 13 (1928), the Court held unconstitutional a New Jersey statute that provided that in an action by a resident against a nonresident for injuries resulting from the nonresident's use of a notor vehicle on a state highway, the summons could be served on the nonresident's Secretary of State. The Court found the statute defective because it contained no provision that inade it reasonably probable that notice of service would reach the defendant. Although the defendant had in fact received notice, the Court nevertheless addressed the merits. Id. at 24. Similarly, in Shaffer v. Heitner, 433 U.S. 186 (1977), the Court held that a Delaware statute allowing the sequestration of property to coinpel the personal appearance of a nonresident to defend a suit brought against him violated the Due Process Clause because it allowed the state to make a binding judgment "against a ... defendant with which the state has no contacts, ties, or relations." Id. at 216 (quoting International Shoe Co. v. Washington, 326 U.S. 310 (1945)). Yet the particular defendants in Shaffer had considerably more contact with Delaware than mere ownership of stock in a Delaware corporation; they were members of the board of the same corporation. Nonetheless, the Court evaluated the statute, not the particular facts of the case.

213. See Monaghan, supra note 24, at $12 \mathrm{n} .49$ (noting that the decision in Wuchter is vulnerable to criticism for ignoring the "Yazoo presunption").

214. When a state utilizes its long-arm statute to assert personal jurisdiction over an absent defendant, it bases its power to adjudicate claims agamst the defendant upon her contacts with the state and upon the procedures authorized for service of process. If the contacts and process are insufficient to support personal jurisdictiou, it should not matter that a different statute might authorize jurisdiction based on legitimate criteria. The statute under which jurisdiction is authorized ignores these other criteria. Thus, for example, im Shaffer $v$. Heitner, the defendants' service on the board of a Delaware corporation arguably would have been sufficient to establish the necessary minimum contacts with the forum state. But the statute made no reference to corporate board membership. 433 U.S. at 190 n.4. One cannot sever from a statute what does not already exist.

One could, of course, attempt to sever the statute's application to a Delaware corporate board member from its application to others. The Court has not generally taken this approach, however, suggesting that, at least regarding absent defendants, states must have statutory authority for the exercise of personal jurisdiction. This premise rests on the apparent distinction betwecn a state court's inherent power to exercise jurisdiction over persons present within the state, see Pennoyer v. Neff, 95 U.S. 714, 720-24 (1877), and the statutory power to subjeet foreign defendants to state process. $C f$. Burnham v. Superior Ct., 495 U.S. 604 (1990) (plurality opinion) (distinguishing traditional from nontraditional bases for personal jurisdiction).

215. I do uot mean to suggest that the constitutional limits on personal jurisdiction are unimportant or insignificant. Nevertheless, one must acknowledge that this topic does not have the wide appeal of other constitutional issues. It would appear more than a bit overstated to argue that due process limits on territorial jurisdiction "contribute[ ] vitally to the preservation of an open, democratic political regime, at the same time as [they] secnre[] rights of high importance to particular individuals." Fallon, supra note 30, at $884 \mathrm{n} .192$ (discussing the speeial inportance of fundamental rights guaranteed under the First Amendment).

216. 481 U.S. 739,745 (1987). 
minish the effects of its actions. ${ }^{217}$

\section{Institutional Limts to the Presumption of Severabitity}

In addition to substantive constitutional law, institutional concerns constrain the legitimate use of a presumption of severability. Questions of justification for the Salerno presumption raise distinctly different issues depending on whether the challenges are to federal or to state laws, though the Supreme Court appears unaware of the distinction.218 One important distinction lies in the area of ultimate interpretive authority. On questions of federal law, the United States Supreme Court retains final authority. In contrast, on questions of state law, the highest court of the state has the last word. Because the difference can be significant, I consider state and federal statutes separately.

\section{A. Facial Challenges to State Statutes}

When a state statute is challenged on federal constitutional grounds, the United States Suprenie Court ${ }^{219}$ and the state's highest court share ultimate

217. Cf. Jean Baptiste Poquelnn Moltére, Le Bourgeois Gentil homme 57 (Yves Brunswick \& Paul Ginestier eds., Librarie Marcel Didier Paris 1968) (1670) (in which Monsieur Jourdain is overjoyed to learn that he already knows how to speak prose, exclaiming, "Quoi! quand je dis: 'Nicole, apportez-moi mes pantoufles et me donnez mon bonnet de nuit,' c'est de la prose?").

218. The Salemo principle finds its first clear expression in Yazoo, a challenge to a state statute. See text accompanying notes 25-28 supra. Salemo itself involved a challenge to a federal law, and cases involving both federal and state laws have invoked the Salemo language. See, e.g., Rust v. Sullivan, 111 S. Ct. 1759, 1767 (1991) (upholding the Department of Health and Human Services' regulations interpreting the Hyde Amendment, a provision of federal law, as facially valid); Webster $v$. Reprod. Health Servs., 492 U.S. 490, 524 (1989) (upholding a Missouri law banning the use of public facilities for abortions as facially valid). The Court recently applied the Salemo standard to a federal regulation facially challenged under the authorizing statute. Reno v. Flores, $113 \mathrm{~S}$. Ct. 1439,1443 (1993).

219. In analyzing the federal courts, 1 focus on the Supreme Court because a ruling by a lower federal court that a state statute is facially invalid is not binding in a later action between different parties in state court. Although no Supreme Court case has squarely decided the question, individual Justices have taken the position that, on questions of federal law, the state courts are bound only by the United States Supreme Court, and not by the lower federal courts. See Lockhart v. Fretwell, 113 S. Ct. 838, 846 (1993) (Thoinas, J., concurring); Steffel v. Thompson, 415 U.S. 452, 482 n.3 (1974) (Rehnquist, J., joined by Burger, C.J., concurring); Perez v. Ledesma, 401 U.S. 82, 125 (1971) (Brennan, J., joined by White and Marshall, JJ., dissenting). This view has gained widespread acceptance in the academic literature as well. See, e.g., Robert M. Cover \& T. Alexander Aleinikoff, Dialectical Federalism: Habeas Corpus and the Court, 86 YALE L.J. 1035, 1053 (1977); Fallon, supra note 30, at 853-54; Daniel J. Meltzer, State Court Forfeitures of Federal Rights, 99 Harv. L. Rev. 1130, 1231 n.495 (1986); David L. Shapiro, State Courts and Federal Declaratory Judgments, 74 Nw. U. L. REv. 759, 771 (1979). State courts also have tended to treat lower federal court precedent as merely persuasive, nonbinding authority. See Bradshaw v. State, 286 So. 2d 4, 6 (Fla. 1973), cert. denied, 417 U.S. 919 (1974) ("It is axiomatic that a decision of a federal trial court, while persuasive if well-reasoned, is not by any means binding on the courts of a State."); Fallon, supra note 30, at 854 n.6 (citing cases in which states have lodged criminal prosecutions against nonparties in a prior lower federal court case which pronounced a state statute void for overbreadth); Shapiro, supra, at $771 \&$ n.68 (arguing that state courts generally consider deference to lower federal court decisions a matter of choice, even when habeas corpus looms on the horizon). One federal appeals court has suggested in dicta that state courts might be bound by decisions of the federal appeals courts on questions of federal law, but free to ignore the decisions of federal district courts. In fact, the court noted that a federal district judge's determination of a federal question "is not even binding on the same judge in a subsequent action." Yniguez v. Arizona, 939 F.2d 727, 736-37 (9th Cir. 1991). To date, no court has adopted this position. 
responsibility for resolving the issue. The highest court of the state interprets the statute, and the United States Supreme Court rules on the constitutionality of that interpretation. However, if the United States Supreme Court holds a state statute unconstitutional, the state court may still salvage it, either by reconsidering the statute's initial interpretation or by severing the unconstitutional portion or applications of the statute from the remainder. ${ }^{220}$

The Salerno principle, however, contradicts essential principles of federalism that apply to the relations between federal and state courts on inatters of . state law. In general, when a federal court must decide a question of state law-either because the dispute substantively concerns state law ${ }^{221}$ or because the court nuust resolve a prehiminary state law question to determine the federal issue 222 - the federal court follows the state's highest court. 223 Federal courts do not siniply assume that every state would resolve the state law question identically; yet that precisely describes what happens under the Salerno approach.

For example, suppose that state $\mathrm{X}$ has a rule of statutory interpretation that holds: "If any clause or application of a statute is unconstitutional, the entire statute shall be invalid, unless the statute contains a severability clause." Although we can imagine good reasons why such a rule might be undesirable, ${ }^{224}$ the rule is not unconstitutional. Suppose further that the legislature of state $\mathrm{X}$ enacts a statute which allegedly has both constitutional and unconstitutional applications. If a litigant whose own conduct is not constitutionally privileged challenges the statute in federal court, the court will uphold the statute, assuming the statute's unconstitutionality does not sten fron a substantive doc-

Even assuming that the standard view is correct, a decision of a lower federal court invalidating a state statute may often prevent enforcement in state court, especially if the challenge in federal court is brought as a class action. Res judicata may give a judgment the force it lacks based solely on stare decisis.

220. A state court may not always be able to salvage a previously invalidated law. For example, the requirement of fair notice means that, at least in criminal cases, no one may be punished for conduct occurring between the statute's invalidation and its resurrection. Fallon argues that for overbreadth doctrine to be most effective, this grace period should extend to all statutes which courts invalidate as overbroad. See Fallon, supra note 30, at 898-99.

221. Diversity cases, see, e.g., Erie R.R. v. Tompkins, 304 U.S. 64 (1938), and federal question cases contaiming pendent or ancillary claims, see 28 U.S.C. § 1367 (Supp. III 1991); United Mine Workers of America v. Gibbs, 383 U.S. 715, 725 (1966), are among the situations in which federal courts are called upon to resolve claims arising under state law.

222. Procedural due process cases fit this paradigm. A federal court looks to state law to determine if it creates "liberty" or "property" interests which are subject to the procedural protection of the Due Process Clause. See, e.g., Bishop v. Wood, 426 U.S. 341, 343 (1976) (ruling that a city ordinance should not be read to confer tenure on all permanent employees).

223. See, e.g., Salve Regina College v. Russell, 499 U.S. 225, 240-41 (1991) (Rehnquist, C.J., joined by White and Stevens, JJ., dissenting on other grounds) (stating that where a federal court must interpret unsettled state law, the court's task is to try to predict how the highest court of that state would decide the question); Rabatin v. Columbus Lines, Inc., 790 F.2d 22, 24 (3d Cir. 1986) ("If . . . the Pennsylvama Supreme Court has not articulated the law in this area, we must predict what rule it would apply.").

224. The unconstitutional applications of the statute may be so far removed froin its legitimate core as to make a rule of nonseverability unwise. This would not be true where important constitutional rights are imvolved. See text accompanying notes 95-190 supra. 
trine that precludes the Salerno severability presumption. ${ }^{225}$

Now suppose that a litigant challenges the same statute in state court and that the statute contains no severability clause. Unlike the federal court, if the state court fimds that the statute has unconstitutional applications, it will hold the statute invalid pursuant to state severability law. The contradictory results in state and federal court are unjustifiable and will lead to forun shopping.

Choice of forum may not be the only problem. After state X's highest court rules that the statute in question is not severable, we would expect federal judges to be obliged to treat it as such. Yet, because the Salerno principle does not expressly address severabihty questions, federal courts applying Salerno to state court ruhings inust ask only whether any circunstances exist under which the state may enforce the statute. Moreover, even if a federal court follows the state court's severability ruling, a litigant challenging the statute in federal court prior to a definitive state court severabihty determination would not benefit; a final judgment in federal court upholding the statute based on the Salerno principle would preclude relitigation.

If the Salerno presumption of severability (in cases not involving the substantive norms discussed in Part II) accurately refiected the law of every state, it might be justifiable. Although state law is remarkably uniform on questions of severability, the Salerno presumption does not encapsulate the law of any state. None of the fifty states employs an irrebuttable presumption of severability. In forty-eight states, whether by judicial decision, statute, or both, courts presume statutes to be severable unless the party claiming nonseverability can show that: (1) severance would leave an incoherent statute, or (2) the legislature would not have enacted the statute without the invalid portion. The two remaining states, Tennessee and Virginia, have a presumption of nonseverability, rebuttable by showing the opposite of these two propositions. In practice, however, Tennessee and Virginia severability cases differ little from those in other states. ${ }^{226}$

As a result, we cannot justify the Salerno presumption of severability as a reflection of state law. Assuming that a federal court could appropriately substitute a generalized version of state severability law for the particular state law in question, ${ }^{227}$ the correct approximation would be a rebuttable presumption of

225. See Part II supra.

226. I summarize the severability law of each state in the appendix.

227. Although the federal courts arguably have limited power to formulate subconstitutional rules of federal common law, see, e.g., City of Milwaukee v. Illinois, 451 U.S. 304, 312-17 (1981) (ruling that federal common law is applicable where no state or federal statute exists that directly addresses the area of dispute); Martha A. Field, Sources of Law: The Scope of Federal Common Law, 99 HARV. L. Rev. 883 (1986) (arguing that federal common law rulemaking powers are broader than generally believed); Meltzer, supra note 219, at 1167-76 (arguing that federal courts have rightfully developed a common law in many specialized areas despite prohibitions against a federal general common law), justifying a federal common law of severability remains difficult. If we consider the Salerno presumption a rule of federal common law, both federal and state courts could apply it. Yet why would a state court ignore state law principles of statutory construction in determining whether a state statute is severable in favor of a federal common law of statutory construction? Certainly no authority supports the application of federal rules of severability in the case of a statute invalidated under a state constitution. Nonetheless, if a state court held invalid a state statute under both the federal and state constitutions, a federal common 
severability, since that represents the law in nearly all jurisdictions. ${ }^{228}$ Sucl a rebuttable presumption, however, is incompatible with Salerno's "no set of circumstances" test.

Federal courts' abihty to follow state severability law is impaired by the fact that the uniformity of state severability law in principle disguises differences in application. Faced with identical statutes, courts in two states may, and often do, reach different conclusions as to severability. Furthermore, federal courts do not always reliably predict whether a state's highest court would deem severable a particular application of a state statute.

In such instances (subject to the substantive limits discussed in Part II), a federal court might justifiably choose to abstain from ruling on a facial challenge pending resolution of the severability question by the state courts. Under Railroad Commission of Texas v. Pullman Co.,229 if a state court resolution of a difficult and unsettled question of state law would avoid the necessity of deciding a federal constitutional question, federal courts should abstain froin entertaining the constitutional challenge unless unreasonable delay would result.

The Pullman doctrine's justification readily applies to questions of severability. ${ }^{230}$ Pullman reflects a judgurent that the risk of an unnecessary decision of federal constitutional law, premised on an erroneous view of state law, outweighs the harm that results when a litigant challenging a state statute must refile her suit in state court. This judgment does not turn on whether the federal constitutional question inay be avoided by a state court's ruling as to a statute's application rather than to its severability. ${ }^{231}$

law of severability would oblige the court to apply federal severability principles to the statute insofar as it violated the United States Constitution and state severability principles to the statute insofar as it violated the state constitution. This anomaly would occur even though the federal and state constitutions invalidate the identical provisions and applications of the statute.

Thus, principles of federalism suggest that a federal court should apply state severability law when considering a facial challenge to a state statute. The task is hardly foreign to the federal courts. For example, in Wyoming v. Oklahoma, 112 S. Ct. 789 (1992), the Court rejected the recommendation of the Special Master suggesting reassertion of the severability issue in a state court. Id. at 803 . The Court reasoned that, at least with respect to cases within its original jurisdiction, complete relief should be afforded, even if in so doing the Court inust resolve a question of state law. Id. In other cases, the Court has discretionary authority to address state severability questions. See Dorchy v. Kansas, 264 U.S. 286, 289-91 (1924) (remanding to state supreme court the question of whether a provision of state legislation closely related to a federal provision found unconstitutional by the Court was severable from the Act).

228. Principles of federalism nnay constrain state severability law. As in other contexts, state courts may not manipulate state law for the purpose of defeating federal rights. See, e.g., NAACP v. Alabama ex rel. Patterson, 357 U.S. 449, 457-58 (1958) (holding that a state court could not inanipulate state law so as to defeat the right to freedom of association); Willianıs v. Georgia, 349 U.S. 375, 399 (1955) (Clark, J., dissenting) (noting that state law, though rightly and honestly applied, may not interfere with plaintiff's right not to be discriminated against). Thus, a state may not create one set of severability rules for challenges to state statutes based on federal grounds and another more permissive set for challenges based on state law. This limitation on a state's ability to discriminate against federal rights should apply to federal cliallenges to state laws regardless of whether litigants bring suit in state or federal court. See Meltzer, supra note 219, at 1158-85.

229. 312 U.S. 496 (1941). For an overview of the Pullman doctrine, see generally BATOR ET AL., supra note 55, at 1359; Field, supra note 73.

230. The Pullman doctrine pertains directly only to situations in which a provision of state law may be inapplicable to the challenging litigant's conduct.

231. Cf. Fallon, supra note 30, at $899-900$ (arguing that the federal courts should use their broad discretion to proffer solutions that reinforce our federal forn of government). 
Pullman abstention on severability grounds is likely the exception rather than the rule. In the absence of applicable substantive constitutional limits on severability analysis, ${ }^{232}$ state law will deem a statute's unconstitutional applications severable in most facial challenges to state statutes. Of the remaining cases, courts will frequently be able to hold the applications nonseverable, either because the severed statute would be plainly imcoherent or because it would clearly violate the intent of the legislature. Thus, federal courts should follow Pullman abstention only in the borderline cases. ${ }^{233}$

Facial challenges to state statutes in federal court may raise statutory construction considerations quite apart from severability issues. As the discussion of overbreadth in the abortion context illustrates, ${ }^{234}$ when the validity of a statutory provision turns on its applicability to persons not before the court, the court need not presume that a state court would construe the statute in an unconstitutional manner as applied to those persons. Rather, federal courts should assume that state courts would prefer a construction of the statute that renders it constitutional. 235 Conversely, if the statute plainly covered the conduct in question, the federal court would not assume that the state court would interpret it at odds with its language. 236

In sum, when a federal court upholds a state statute against a facial challenge on the basis that the statute could be construed to avoid constitutional infirmities, the court, in effect, abstains from rendering a decision of state law pursuant to Pullman. Therefore, the party challenging the statute should be allowed to refile her challenge in state court. Abstention, as a doctrine of comity, does not require that state laws be insulated from constitutional scrutiny.

The concerus addressed in this section are based on principles of federalism. Consequently, most are inapplicable in state court. When a state statute is challenged in state court on federal constitutional grounds and the court wishes to avoid a federal constitutional holding, the principle that no person may be judged by an unconstitutional rule of law requires the state court to decide the case on state statutory grounds-whether rooted in severability doctrine or in a judgment that the statute does not reach certain conduct. Thus, althougl the Salerno irrebuttable presumption of severability is never appropriate, the underlying substantive constitutional doctrine may justify the application of a close cousin of Salerno. This more moderate principle may help channel state law questions into state court, an entirely appropriate result in light of the federalism concerus I have discussed.

232. Pullman abstention would not be appropriate in First Amendment or other fundamental rights overbreadth cases where the cost of abstention is to perpetuate a law's unconstitutional chilling effect while the federal court awaits an authoritative severability ruling by the state's highest court.

233. The test for determining when "an issue of state law [is] sufficiently 'unsettled' or 'unclear' to warrant abstention under the Pullman doctrine ... does not emerge easily from analysis of the decisions . . . ." BATOR ET AL., supra note 55, at 1359.

234. See text accoinpanying notes 141-168 supra.

235. See, e.g., Planned Parenthood Ass'n v. Ashcroft, 462 U.S. 476, 493 (1983) ("Where fairly possible, courts should construe a statute to avoid a danger of unconstitutionality.").

236. See, e.g., City of Houston v. Hill, 482 U.S. 451, 468 (1987) (holding that a city ordinance was not susceptible to a limiting construction as its language was plain and unambiguous). 


\section{B. Facial Challenges to Federal Statutes}

If a litigant challenges a federal statute on federal constitutional grounds in the United States Supreme Court, ${ }^{237}$ the Court can give an authoritative construction to the statute in the course of deciding the constitutional challenge, apply the familiar canon of constitutional avoidance, ${ }^{238}$ or, should this expedient be unavailable, render a final determination on the severability of the statutory phrases and applications. In the case of a federal statute, the Court need not predict or presume anything about severability.

The traditional test to determine whether the Court should treat an invalidated provision of a federal statute as severable from the rennainder differs little froin the standard applicable in each state. As one commentator noted: "The oft-stated test of severability [asks] whether Congress would have passed the statute absent the invalidated section."239 Like the state formulae it resembles, this general rule offers little instruction. A richer understanding of federal severability law can be gleaned froin the cases.

I.N.S. v. Chadha ${ }^{240}$ exemplifies the modern Court's approach to severability. In Chadha, the Court invalidated the one-house legislative veto provision of the Immigration and Nationality Act $^{241}$ because it authorized Congress to legislate without complying with the constitutional requirements of bicameralism and presentment to the President. Before addressing the constitutional question, the Court considered the argument, advanced by Congress, ${ }^{242}$ that the Court could not sever the legislative veto provision from the remainder of the Act.

Notably, the Court treated severability as a threshold question, terming the nonseverability argument a "challenge[] to the authority of this Court to re-

237. For simplicity, I focus here on the United States Supreme Court. Most of the following observations, however, also apply with nearly equal force to cases involving facial challenges to federal statutes in the lower federal courts as well as the state courts since these courts are bound by the same federal constitutional and statutory law as the United States Supreme Court.

In addition, many of the following points also apply to cases imvolving state statutes challenged in state court on state constitutional grounds. In such a case, the highest court of the state determines both the meaning and the legitinuacy of the statute under the state's constitution. There is, however, one caveat. While the doctrine of separation of powers to some extent shapes the practice of the United States Supreme Court in evaluating federal statutes, such considerations will not be apphicable to cases brought in a state court that is bound by a state constitution that lacks a separation of powers principle. See, e.g., Elrod v. Burns, 427 U.S. 347, 352 (1976) ("[T]he separation-of-powers principle . . . has no applicability to the federal judiciary's relationship to the states."); Sweezy v. New Hampshire, 354 U.S. 234, 255 (1957) ("[T]he separation of powers . . . concept is not mandatory in state governments."); Dreyer v. lllinois, 187 U.S. 71, 83-84 (1902) (holding that adherence to separation of powers at the state level is for the determination of the state). Still, many state constitutions contain a principle of separation of powers, and, as to these states, the separation of powers considerations discussed in this section are relevant.

238. See, e.g., Edward J. DeBartolo Corp. v. Florida Gulf Coast Bldg. \& Constr. Trades Council, 485 U.S. 568, 575 (1988); NLRB v. Catholic Bishop of Chicago, 440 U.S. 490, 500 (1979).

239. Note, The Aftermath of Chadha: The Impact of the Severability Doctrine on the Management of Intragovernmental Relations, 71 VA. L. REv. 1211, 1213 (1985).

240. 462 U.S. 919 (1983).

241. 8 U.S.C. $\$ 1254(c)(2)$ (1982) (current version at 8 U.S.C. $\S 1254$ (c) (1988)).

242. 462 U.S. at 931 . The Immigration and Naturalization Service took the position that the legislative veto was unconstitutional, agreeing with respondent Chadha. The Court held that Congress could intervene as an appropriate party to defend the provision's constitutionality. 
solve" the underlying constitutional question. ${ }^{243}$ Although, strictly speaking, the Court would not have lacked the authority to consider the constitutionality of the legislative veto if the Court found it nonseverable, the basic point remains sound: Severability presents a question of statutory interpretation, and courts should avoid deciding a constitutional question by resolving a statutory one whenever possible.

Thus, we derive our first principle of federal severability law: Subject to the substantive limits discussed in Part II, courts should address severability before constitutionality. Especially in facial challenge cases, treatment of severability as a preliminary issue can obviate the need to resolve a constitutional question. 244

Chadha also sheds light on the proper treatment of severability clauses. As the Court noted, the Immigration and Nationality Act's inclusion of a severability clause meant that "Congress itself has provided the answer to the question of severability ...."245 One might think that a clause providing that, "[i]f any particular provision of this Act, or the application thereof to any person or circumstance, is held invalid, the remainder of the Act and the application of such provision to other persons or circumstances shall not be affected thereby"246 would have disposed of the severability issue. Yet the Court treated the clause as raising only a presumption of severability, rebuttable by a showing of contrary congressional intent. Only after canvassing Congress' reasons for enacting the relevant provisions of the Immigration and Nationality Act did the Court conclude that the "legislative history is not sufficient to rebut the presumption of severability raised by" the severability clause. ${ }^{247}$

Why did the Court in Chadha treat the severability clause as establishing a rebuttable rather than an irrebuttable presumption of severability? One possibility is that overriding a severability clause may be necessary when severing an unconstitutional provision or application would leave a nonsensical or unworkable statute. ${ }^{248}$ For example, suppose that Congress were to pass a statute

243. Id. at $929,931 \mathrm{n} .7$.

244. Chadha itself was not a facial challenge. Instead, the respondent mounted an as-applied attack to $\S 244(\mathrm{c})(2)$ of the Immigration and Nationality Act, 8 U.S.C. $\S 1254(c)(2)$, which gave either house of Congress the power to override the Attorney General's decision to suspend deportation of an otherwise deportable alien. Congress argued that the legislative veto provision could not be severed from the remainder of $\S 244$ of the Act. Since invalidation of $\$ 244$ in its entirety would have negated the Attorney General's authority to suspend deportation of the respondent, a holding of nonseverability would have defeated Chadha's claim to relief. By contrast, im a typical overbreadth case, a finding of severability denies relief to the party challenging an act of Congress. This distinction does not, however, alter the basic analysis in the text. In short, if the resolution of a severability question-im either direction-avoids the need to resolve a constitutional question, the Court will address the severability question first.

245. 462 U.S. at 932.

246. Id. (quoting $\S 406$ of the Immigration and Nationality Act, 8 U.S.C. $\$ 1101$ ) (emphasis removed).

247. Id. at 934; see also United States v. Jackson, 390 U.S. 570, 585 n.27 (1968) (stating that "the ultinate determination of severability will rarely turn on the presence or absence of [a severability] clause"); Carter v. Carter Coal Co., 298 U.S. 238, 312 (1936) (noting that the determination of severability will, in the end, turn on the intent of the lawmakers).

248. See, e.g., Hill v. Wallace, 259 U.S. 44, 70-72 (1922) (holding the Future Trading Act nonseverable where valid and invalid provisions were inextricably intertwined). Curing one constitutional 
requiring: (1) the licensing of all common carriers doing business in interstate commerce; and (2) the payinent of a tax of $95 \%$ of the value received by any common carrier doing business in interstate commerce without a license. Assume that a court holds. the licensing scheme invalid because the required procedures violate procedural due process. Even if the statute contains a severability clause, a court could reasonably hold the taxation provision nonseverable froin the licensing provision. Consider the alternative: A court might hold the licensing scheme void, but find the taxation provision severable. After all, a high tax on interstate commerce presents no per se constitutional violation. But if the inanifest purpose of the tax is to punish those who do not comply with the registration requirement, then a court should treat the registration requirement and the tax as nonseverable. We might characterize this as rebutting the severability clause's presumption, as Chadha suggests, or, to be more faithful to the text of a severability clause, we might describe the registration requirement and the tax penalty as a unitary "provision" within the meaning of the severability clause. Under this interpretation, the provision no longer falls within the clause's scope.

Chadha also suggests that even if severance leaves a workable, coherent statute, a court inay nonetheless override a severability clause on a showing that, as a historical matter, Congress would not have enacted the statute absent the clause in question. In looking at the political process of enactment, the Court asks whether the statute's invalid provision was so critical to the bargain Congress struck that the legislation would not have been passed in its absence. ${ }^{249}$ For instance, in Chadha, the Court found that Congress considered the burden of private immigration bills so onerous that it would have delegated authority to the Attorney General to suspend deportations anyway, even without reserving a legislative veto. 250 Obviously, such findings are tenuous. As Justice White noted in his Chadha dissent, the legislative veto may just as well have played a central role in Congress' willingness to grant these additional powers to the Attorney General. 251

To summarize, current federal severability law turns on the sanie two-part

infirmity by severance may create other constitutional problems, especially in criminal cases. See Robert L. Stern, Separability and Separability Clauses in the Supreme Court, 51 HaRv. L. REv. 76, 87-89 (1937) (discussing reasons for the Court's inconsistent treatment of severability). Stern argues that different rules ought to apply to civil and criminal cases. Id. Althougl he recognizes that this distinction is unsupported by the cases, he suggests that considerations of fair notice-always a greater factor in criminal than civil cases-constrain severability doctrine. Id. In short, Stern posits that, regardless of whether there is a severability clause, the requirement of due process prohibits severing a criminal law's unconstitutional provisions if sucl severance might render individuals unable to discem acts that are criminal under the statute from those that are not. See note 80 supra.

249. Chadha, 462 U.S. at 931-32. The Court later focused explicitly on the congressional bargaining process in another legislative veto case, Alaska Airlines, Inc. v. Brock, 480 U.S. 678 (1987). After concluding that the statutory program in question could function absent the legislative veto, the Court turned to "[t]he inore relevant inquiry ... [of] whether the statute will function in a manner consistent with the intent of Congress." Id. at 685 (emphasis in origimal). One important factor in determining this imtent, according to the Court, is "the importance of the [invalidated legislative] veto in the original legislative bargain ...." Id.

250. 462 U.S. at 935 n.8.

251. Id. at 979 n. 16 (White, J., dissenting). 
test that the states use. A court can hold an invalid provision of a statute severable if: (1) the remaining statute functions as a coherent whole; and (2) the evidence does not show that Congress would not have enacted the statute absent the invalid provision. ${ }^{252}$ While the first portion of the test appears unobjectionable, the second part-focusing on Congress' legislative bargainrequires a more rigorous analysis.

Contrary to the Court's analysis in Chadha, if the statute in question contains a severability clause, the clause should settle the matter of congressional intent. Speculating whether Congress, faced with different circumstances, would have passed a statute it did not in fact pass is a considerably more uncertain enterprise than searching legislative history for the meaning of a statute Congress did pass. Moreover, even if a court knew that Congress would not have enacted a statute absent the invalidated provision, that hardly provides a sufficient basis for invalidating the entire statute. By including a severability clause, Congress knowingly took the risk that a court would invalidate a part or an application of the statute and let stand the remainder, subject to the substantive constitutional limits outlined in Part II and the requirement of a workable statute-even though Congress would not have initially enacted the remainder as a separate statute. ${ }^{253}$

In practice, the second prong of the severability test-whether Congress would have passed the statute absent a specific provision-may carry no real force. For exainple, in the recent case of New York $v$. United States, 254 although the Court stated the traditional two-part severability test, ${ }^{255}$ it only applied the first prong, focusing exclusively on how the statute functioned absent the invalid provision. The Court concluded: "The purpose of the Act is not defeated by the invalidation of the take title provision, so we may leave the remainder of the Act in force."256 Indeed, the Court has never actually refused to sever a statute solely on the historical basis that Congress would not have passed it absent the invalid provision. ${ }^{257}$

Because the statute in question in New York $v$. United States had no sever-

252. Buckley v. Valeo, 424 U.S. 1, 108 (1976) (per curiam) (" 'Unless it is evident that the Legislature would not have enacted those provisions which are within its power, independently of that which is not, the invalid part may be dropped if what is left is fully operative as a law.'") (quoting Champlin Ref. Co. v. Corporation Comm'n of Okla., 286 U.S. 210, 234 (1932)).

253. Since the Court has interpreted severability clauses as establishing only a rebuttable presumption of severability, see note 259 infra, one might wish to apply that rule of construction to statutes enacted in reliance upon it. Any judicial change in the effect given to severability clauses should therefore be prospective only.

254. 112 S. Ct. 2408 (1992).

255. Id. at 2434 (quoting Alaska Airlines, Inc. v. Brock, 480 U.S. 678, 684 (1987)).

256. Id.

257. The Court has, however, held acts of Congress nonseverable because it could not tell whether or not Congress would prefer severability. See, e.g., Northern Pipeline Constr. Co. v. Marathon Pipe Line Co., 458 U.S. 50, 87 n.40 (1982) (plurality opinion) (refusing to sever bankruptcy judges' jurisdiction over state law claims from the other provisions of the Bankruptcy Act of 1978). In doing so, however, the Court did not rely solely on the historical evidence of the congressional bargaining process, but essentially applied a presumption of nonseverability without explanation. See id. at 95 n.3 (White, J., dissenting). 
ability clause, ${ }^{258}$ this case presented an opportunity to use its legislative history to discern Congress' actual intent. ${ }^{259}$ The Court's failure to do so illustrates the weakness of the second prong of severability analysis. The only real test of severability for all practical purposes is whether the remaining statute can function as a coherent whole. ${ }^{260}$

As Chadha and New York illustrate, the function-oriented severability test may rest on principles of legislative supremacy and judicial restraint. The first principle dictates that courts will not disturb congressional policies reflected in legislation, except insofar as the Constitution requires. The second principle plays a more subtle role. Since the Court addresses severability first, before the merits of a constitutional claim-and because this inquiry's result will usually support severability-the Court can avoid unnecessary constitutional adjudication. These policies provide a strong justification for applymg the existing standard to facial challenges just as to other cases presenting severability issues.

Nonetheless, the standard's heavy bias towards finding statutes severable threatens the separation of powers between Congress and the judiciary. A corollary of legislative supremacy is the principle that the judiciary should not rewrite statutes. Shrill accusations of "legislation from the bencli" ring hollow when only the interpretation of the Constitution or an act of Congress is at stake, 261 but the cries may ring true when the Court severs an imvalid statutory provision. In so doing, it substitutes a judicially rewritten law, stating, "there

\section{8. $112 \mathrm{~S}$. Ct. at 2434.}

259. The Court makes no presumption based on the absence of a severability clause. "In the absence of a severability clause," the Court has noted, "Congress' silence is just that-silence-and does not raise a presumption against severability." Alaska Airlimes, Inc. v. Brock, 480 U.S. 680,686 (1987) (citing Tilton v. Richardson, 403 U.S. 672, 684 (1971) (plurality opinion)); United States v. Jackson, 390 U.S. 570, 585 n.27 (1968).

260. The Court's severability approacl appears to exemplify the "public choice" school of statutory interpretation. As Judge Easterbrook once expressed it, "judicial predictions of how the legislature would lave decided issues it did not in fact decide are bound to be little more than wild guesses." Frank H. Easterbrook, Statutes' Domains, 50 U. ChI. L. Rev. 533, 548 (1983). Thus, the Court's reluctance to employ legislative history to override the presumption of severability seems consistent with public choice theories. However, public clioice theory also postulates that a statute has no spirit or purpose apart from the concrete deal a legislature struck in a given enactment. See, e.g., Frank H. Easterbrook, The Supreme Court 1983 Term-Foreword: The Court and the Economic System, 98 HARv. L. REv. 4, 15-17 (1984). This principle suggests that the presumption of severability is itself mistaken. Under public choice theory, courts should presume that Congress intended exactly the statute it enacted. Hence, if a court invalidates any provision, public choice theory suggests that the court should invalidate the whole statute.

Because public choice theory cannot explain federal severability law, a different theoretical framework must be found to justify it. That framework is most likely to be found in a nonintentionalist school of statutory interpretation whicl nevertheless allows some scope for legislative purpose. For examples of suclı theories, see, e.g., Cass R. Sunstein, Interpreting Statutes in the Regulatory State, 103 HARv. L. REv. 405 (1989) (arguing that courts should follow congressional instructions or, in their absence, norms that focus disputes over statutory meaning on the underlying issues); William N. Eskridge, Jr., Dynamic Statutory Interpretation, 135 U. PA. L. Rev. 1479 (1987) (outlining a method of dynamic judicial interpretation of statutes in light of their current and historical context).

261. Cf. James B. Beam Distilling Co. v. Georgia, 111 S. Ct. 2439, 2451 (1991) (Scalia, J., joined by Marshall and Blackmun, JJ., concurring in the judgment) (recognizing "that judges in a real sense 'make' law"). 
shall be a legal duty $X$ except under circumstance $Y$ " for the law actually enacted, "there shall be a legal duty X."

Judicial willingness to stand in for Congress not only blurs the lines of power between the branches, ${ }^{262}$ but also encourages congressional laziness in matters of constitutional principle. Members of Congress, no less than judges, are constitutionally obligated to obey the Constitution. So long as Congress knows that constitutional infirmities in its legislation will affect only minimally the remainder of its work, the incentive to pass only constitutional laws diminishes. At worst, strict judicial enforcement of severability clauses, coupled with a preference for severability even in the absence of such clauses, encourages Congress to view the constitutionality of its statutes as solely a judicial matter.

To some extent, the constraints placed on severability law by the substantive doctrines explored in Part II help to check congressional incentives to abdicate its constitutional responsibility. Recall that if Congress passes a law to defeat a constitutional guarantee, the law's invalid purpose will infect the entire statute. Moreover, overbreadth analysis of laws infringing First Amendment and other fundamental rights encourages legislative attention to the Constitution. ${ }^{263}$ The risk of congressional laxity may therefore only be substantial when Congress neither aims at constitutional safeguards nor infringes First Amendment or other fundamental rights.

The question remains whether severability law should be substantially reformed. I would argue that it should not. For even if the built-in substantive safeguards leave us uneasy about whether Congress recognizes its duty to enforce the Constitution, this concern alone does not justify a complete overhaul of severability law. Ideally, when the Court applies its severability test and asks whether what remains of a statute after severing the invalid provision " is fully operative as a law," "264 it should be aware that part of what makes a statute "operative" is its passage in accordance with constitutionally prescribed procedures. In the end, judicially crafted rules can only go so far towards ensuring that Congress fulfills its constitutional role. The ultimate responsibility rests with Congress itself.

262. The view that each branch of government exercises only a limited power-the legislature creates laws, the executive executes them, and the judiciary interprets them-is, of course, an oversimplification. In reality power is allocated much more subtly. In Justice Jackson's justly famous words:

The actual art of governing under our Constitution does not and cannot conform to judicial definitions of the power of any of its branches based on isolated clauses or even single Articles torn from context. While the Constitution diffuses power the better to secure liberty, it also contemplates that practice will integrate the dispersed powers into a workable government. Youngstown Sheet \& Tube Co. v. Sawyer, 343 U.S. 579, 635 (1952) (Jackson, J., concurring).

263. Fallon, supra note 30 , at $888-89$ (suggesting that legislators' fear of having statutes completely invalidated encourages them to write narrower laws when regulating expressive activity).

264. Buckley v. Valeo, 424 U.S. 1, 108 (1976) (per curiam) (quoting Champlin Ref. Co. v. Corporation Comm'n of Okla., 286 U.S. 210, 234 (1932)). 


\section{Conclusion}

United States $v$. Salerno suggests that a court confronted with a facial challenge to a state or federal statute should simply ask whether the law is capable of any constitutional applications. If it is, the challenge fails. As I argue above, that standard finds little support in the Supreme Court's cases and is unsound in principle. Moreover, the Salerno principle contains a more basic flaw: It assumes all constitutional cases divide neatly into categories of "facial" and "as-applied" challenges, and that one set of rules suffices for all possible situations in each category.

The distinction between as-applied and facial challenges may confuse more than it illuminates. ${ }^{265}$ In some sense, any constitutional challenge to a statute is both as-applied and facial. It is as-applied in the sense that adjudication in federal court, and often in state court, requires that the statute be applied to the litigant to create a case or controversy. Every challenge to a statute is also facial in that it attacks the statute that authorized the contested government action. ${ }^{266}$ Thus, although I have used the terms "facial" and "as-applied" throughout this article, tracking the Court's vocabulary, the discussion above reveals that the proper approach to a constitutional case typically turns on the applicable substantive constitutional doctrine and the institutional setting, not the classification of a case as a facial or as-applied challenge. Abandoning Salerno and eliminating the distinction between facial and as-applied challenges would focus courts more sharply on the real issues-both subconstitutional and constitutional-at the core of any challenge to a statute.

Courts should work to avoid constitutional questions altogether by construing challenged statutes to make them constitutional, or by severing unconstitutional provisions or applications from the particular provisions or applications before the court. If this fails, however, the subconstitutional policy of constitutional avoidance must give way to more fundamental substantive and institutional constitutional norms.

265. Prior to 1988, the Supreme Court could not entirely avoid distinguishimg facial from asapplied challenges because 28 U.S.C. $\$ 1257$ (1964) provided for mandatory appellate jurisdiction in all cases in which a state's highest court either sustained a state statute against a claim that it violated a federal law or invalidated a federal statute. The Court granted only discretionary review by way of a petition for a writ of certiorari in cases in which a court questioned the constitutionality of a statute or in which a constitutional "title, right, privilege or immunity" was claimed. 28 U.S.C. $§ 1257$ (1964). Justice Brandeis argued that the inost natural reading of the then-current provision would have allowed an appeal of an unsuccessful "facial" challenge, but jurisdiction only by way of certiorari in other constitutional cases. Dahnke-Walker Milling Co. v. Bondurant, 257 U.S. 282, 293-303 (1921) (Brandeis, J., joined by Clarke, J., dissenting). But the Court did not follow that course. Id. at 287-90. Instead, Justice Van Devanter, author of the opinion in Yazoo, wrote for the Court in Dahnke-Walker that, since a statute may only be challenged in its application to a particular litigant, the distinction proffered by Justice Brandeis would elimmate appellate jurisdiction entirely. Id. at 289 (citing Yazoo \& Miss. Valley R.R. v. Jackson Vinegar Co., 226 U.S. 217 (1912)). Nonetheless, in subsequent cases the Court did not allow all unsuccessful constitutional claims to be heard on writ of error, leading to considerable confusion over the facial/as-applied distinction. See generally BATOR Er AL., supra note 55, at 717-21. Now that Congress has eliminated virtually all of the Court's inandatory appellate jurisdiction, see 28 U.S.C. $\S 1257$ (1988), this reason for distinguishing between facial and as-applied challenges has vanished.

266. Discriminatory enforcement of a neutral statute is best seen as a challenge to the discrimination, simpliciter, and not to the statute. 


\section{APPENDIX}

Severability Law in the Individual States

As discussed above, ${ }^{267}$ state severability law is remarkably uniform. Every state except Tennessee and Virginia employs a presumption of severability, unless the statute in question mcludes a nonseverability clause. In general, state courts loold that provisions and applications of statutes are severable.

I list below the most recent severability case from the higliest court in each state. For those states in which the general rule of severability is codified, I give the statutory provision and language.

\section{ALABAMA}

City of Birmingham v. Smith, 507 So. 2d 1312 (Ala. 1987).

\section{ALASKA}

Sonneman v. Hickel, 836 P.2d 936 (Alaska 1992).

The Alaska Statutes contain a general severability provision:

Any law heretofore or hereafter enacted by the Alaska legislature which lacks a severability clause shall be construed as though it contained the clause in the following language, "If any provision of this Act, or the application thereof to any person or circumstance is held invalid, the remainder of this Act and the application to other persons or circumstances shall not be affected thereby."

Alaska Stat. $\$ 01.10 .030$ (1990). The provision creates only a weak presumption in favor of severability. Sonneman, 836 P.2d at 941.

\section{ARIZONA}

Republic Inv. Fund v. Town of Surprise, 166 Ariz. 143, 800 P.2d 1251 (1990).

\section{ARKANSAS}

Cartwright v. Carney, 286 Ark. 121, 690 S.W.2d 716 (1985).

\section{CALIFORNIA}

Calfarm Ins. Co. v. Deukmejian, 48 Cal. 3d 805, 771 P.2d 1247, 258 Cal. Rptr. 161 (1989).

\section{COLORADO}

People v. District Court, 834 P.2d 181 (Colo. 1992).

Colorado's severability doctrine is codified at Colo. REv. STAT. ANN. § 24-204 (West 1989), whicli provides:

If any provision of a statute is found by a court of competent jurisdiction to be unconstitutional, the remaining provisions of the statute are valid, unless it appears to the court that the valid provisions of the statute are so essentially and 
inseparably connected with, and so dependent upon, the void provision that it cannot be presumed the legislature would have enacted the valid provisions without the void one; or unless the court determines that the valid provisions, standing alone, are incomplete and are incapable of being executed in accordance with the legislative intent.

\section{CONNECTICUT}

Payne v. Fairfield Hills Hosp., 215 Conn. 675, 578 A.2d 1025 (1990).

The Connecticut General Statutes contain a universal severability provision: "If any provision of any act passed by the general assembly or its application to any person or circumstances is held invalid, such invalidity shall not affect other provisions or applications of such act." ConN. GEN. STAT. ANN. § 1-3 (West 1988).

\section{DELAWARE}

In re Oberly, 524 A.2d 1176 (Del. 1987).

Del. Code ANN. tit. 1, $\$ 308$ (1985) provides:

If any provision of this Code or amendments hereto, or the application thereof to any person, thing or circumstances is held invalid, such invalidity shall not affect the provisions or application of this Code or sucli amendments that can be given effect without the invalid provisions or application, and to this end the provisions of this Code and such amendments are declared to be severable.

\section{FLORIDA}

Schmitt v. State, 590 So. 2d 404 (Fla. 1991), cert. denied, 112 S. Ct. 1572 (1992).

\section{GEORGIA}

Cunningham v. State, 260 Ga. 827, 400 S.E.2d 916 (1991).

HAWAII

State v. Bloss, 62 Haw. 147, 613 P.2d 354 (1980).

\section{IDAHO}

Lynn v. Kootenai Fire Protective Dist. No. 1, 97 Idaho 623, 550 P.2d 126 (1976).

\section{ILLINOIS}

People ex rel. Chicago Bar Ass'n v. State Bd. of Elections, 136 Ill. 2d 513, 558 N.E.2d 89 (1990).

\section{INDIANA}

Brady v. State, 575 N.E.2d 981 (Ind. 1991). 
Indiana also has a severability statute:

(b) Except in the case of a statute containing a nonseverability provision, each part and application of every statute is severable. If any provision or application of a statute is held invalid, the invalidity does not affect the remainder of the statute unless:

(1) the reniainder is so essentially and inseparably connected with, and so dependent upon, the invalid provision or application that it cannot be presumed that the remainder would have been enacted without the invalid provision or application; or

(2) the remainder is incomplete and incapable of being executed in accordance with the legislative intent without the invalid provision or application.

IND. CODE ANN. § 1-1-1-8 (West 1981).

\section{IOWA}

Western Int'1 v. Kirkpatrick, 396 N.W.2d 359 (Iowa 1986).

Iowa law includes a general severability provision in its statutory construction section:

If any provision of an Act or statute or the application thereof to any person or circumstance is held invalid, the invalidity does not affect other provisions or applications of the Act or statute which can be given effect without the invalid provision or application, and to this end the provisions of the Act or statute are severable.

Iowa CODE ANN. $\$ 4.12$ (West 1989).

\section{KANSAS}

State v. Rupert, 802 P.2d 511 (Kan. 1990).

\section{KENTUCKY}

Kentucky Mun. League v. Commonwealth Dep't of Labor, 530 S.W.2d 198 (Ky. 1975).

Ky. Rev. Stat. Ann. $\$ 446.090$ (Baldwin 1992) provides:

It shall be considered that it is the intent of the General Assembly, in enacting any statute, that if any part of the statute be held unconstitutional the remaining parts shall remain in force, unless the statute provides otherwise, or unless the remaining parts are so essentially and inseparably connected with and dependent upon the unconstitutional part that it is apparent that the General Assembly would not have enacted the remaining parts without the unconstitutional part, or unless the remaining parts, standing alone, are incomplete and incapable of being executed in accordance with the intent of the General Assembly.

\section{LOUISIANA}

State v. Russland Enter., 555 So. 2d 1365 (La. 1990). 


\section{MAINE}

Bayside Enter. v. Maine Agric. Bargaining Bd., 513 A.2d 1355 (Me. 1986).

Maine has a general stațutory construction statute which sets forth its severability presumption:

The following rules shall be observed in the construction of statutes, unless such construction is inconsistent with the plain meaning of the enactment.

8. Severability. The provisions of the statutes are severable. The provisions of any session law are severable. If any provision of the statutes or of a session law is invalid, or if the application of either to any person or circumstance is invalid, such invalidity does not affect other provisions or applications which can be given effect without the invalid provision or application. The repeal of a severability clause located in and applicable to any title or a division of a title, chapter, section or Act, must be construed as the reinoval of surplus language unless the law indicates otherwise.

Me. Rev. Stat. AnN. tit. 1, § 71 (West Supp. 1992).

\section{MARYLAND}

Board of Supervisors of Elections v. Smallwood, 327 Md. 220, 608 A.2d 1222 (1992).

\section{MASSACHUSETTS}

Mayor of Boston v. Treasurer and Receiver Gen., 384 Mass. 718, 429 N.E.2d 691 (1981).

\section{MICHIGAN}

Baldwin v. North Shore Estates Ass'n, 384 Mich. 42, 179 N.W.2d 398 (1970). Michigan has a statutory severability presumption, Мich. СомP. Laws ANN. $\S 8.5$ (West 1992), which reads:

\subsection{Severability clause}

Sec. 5. In the construction of the statutes of this state the following rules shall be observed, unless such construction would be inconsistent with the manifest intent of the legislature, that is to say: If any portion of an act or the application thereof to any person or circumstances shall be found to be invalid by a court, such invalidity shall not affect the remaining portions or applications of the act which can be given effect without the invalid portion or application, provided such remaining portions are not determined by the court to be inoperable, and to this end acts are declared to be severable.

\section{MINNESOTA}

Johnson Bros. Wholesale Liquor Co. v. Commissioner of Revenue, 402 N.W.2d 791 (Minn. 1987).

Minnesota has a statutory severability presumption, MinN. STAT. ANN. $\S 645.20$ (West 1993), which reads: 
645.20. Construction of severable provisions: Unless there is a provision in the law that the provisions shall not be severable, the provisions of all laws shall be severable. If any provision of a law is found to be unconstitutional and void, the remaining provisions of the law shall remain valid, unless the court finds the valid provisions of the law are so essentially and inseparably counected with, and so dependent upon, the void provisions that the court cannot presunie the legislature would have enacted the reniaining valid provisions without the void one; or unless the court finds the remaining valid provisions, standing alone, are incomplete and are incapable of being executed in accordance with the legislative intent.

\section{MISSISSIPPI}

Quinn v. Branning, 404 So. 2d 1018 (Miss. 1981).

\section{MISSOURI}

Millsap v. Quinn, 785 S.W.2d 82 (Mo. 1990).

\section{MONTANA}

Ingraham v. Champion Int'1, 243 Mont. 42, 793 P.2d 769 (1990).

NEBRASKA

Robotham v. State, 241 Neb. 379, 488 N.W.2d 533 (1992).

\section{NEVADA}

Brewery Arts Ctr. v. State Bd. of Examiners, 108 Nev. 1050, 843 P.2d 369 (1992).

\section{NEW HAMPSHIRE}

Carson v. Maurer, 120 N.H. 925, 424 A.2d 825 (1980).

\section{NEW JERSEY}

Chamber of Commerce v. State, 89 N.J. 131, 445 A.2d 353 (1982).

\section{NEW MEXICO}

Bradbury \& Stamm Constr. Co. v. Bureau of Revenue, 70 N.M. 226, 372 P.2d 808 (1962).

\section{NEW YORK}

Association of Surrogates and Supreme Court Reporters v. State, 79 N.Y.2d 39, 588 N.E.2d 51, 580 N.Y.S.2d 153 (1992).

\section{NORTH CAROLINA}

Flippin v. Jarrell, 301 N.C. 108, 270 S.E.2d 482 (1980). 


\section{NORTH DAKOTA}

First Bank of Buffalo v. Conrad, 350 N.W.2d 580 (N.D. 1984).

North Dakota has a statutory severability presumption, N.D. Cent. Code $\S 1-02-20$ (1987) which reads:

1-02-20. Interpretation. In the event that any clause, sentence, paragraph, chapter, or other part of any title, is adjudged by any court of competent or final jurisdiction to be invalid, such judgment does not affect, impair, nor imvalidate any other clause, sentence, paragraph, chapter, section, or part of such title, but is confined in its operation to the clause, sentence, paragraph, section, or part thereof directly involved in the controversy in which such judgment has been rendered.

\section{OHIO}

Emmons v. Keller, 21 Ohio St. 2d 48, 254 N.E.2d 687 (1970), overruled on other grounds by Delozier v. Sommer, 38 Ohio St. 2d 268, 313 N.E.2d 386 (1974), and Kinney v. Kaiser Aluminum \& Chemical Corp., 41 Ohio St. 2d 120,322 N.E.2d 880 (1975).

Ohio has a statutory severability provision, OHIo REv. Code ANN. $\S 1.50$ (Anderson 1990), which reads:

1.50 Severability of Code section provisions. If any provisions of a section of the Revised Code or the application thereof to any person or circumstance is held invalid, the invalidity does not affect other provisions or applications of the section or related sections which can be given effect without the imvalid provision or application, and to this end the provisions are severable.

\section{OKLAHOMA}

Tulsa Exposition \& Fair Corp. v. Board of County Comm'rs, 468 P.2d 501 (Okla. 1970).

\section{OREGON}

City of Portland v. Dollarhide, 300 Or. 490, 714 P.2d 220 (1986).

For acts of the Oregon Legislative Assembly, the severability principle has been codified at Or. Rev. STAT. § 174.040 (1990), which provides:

It shall be considered that it is the legislative intent, in the enactment of any statute, that if any part of the statute is held unconstitutional, the remaining parts shall remain in force unless: (1) The statute provides otherwise; (2) The remaining parts are so essentially and inseparably conneeted with and dependent upon the unconstitutional part that it is apparent that the remaining parts would not have been enacted without the unconstitutional part; or (3) The remaining parts, standing alone, are incomplete and incapable of being executed in accordance with the legislative intent. 


\section{PENNSYLVANIA}

Hopewell Township Bd. of Supervisors v. Golla, 499 Pa. 246, 452 A.2d 1337 (1982).

Pennsylvania has a statutory severability provision, 1 PA. Cons. STAT. ANN. § 1925 (1992), which reads:

The provisions of every statute shall be severable. If any provision of any statute or the application thereof to any person or circumstance is held invalid, the remainder of the statute, and the application of such provision to other persons or circumstances, shall not be affected thereby, unless the court finds that the valid provisions of the statute are so essentially and inseparably connected with, and so depend upon, the void provision or application, that it cannot be presumed the General Assembly would have enacted the remaining valid provisions without the void one; or unless the court finds that the remaining valid provisions, standing alone, are incomplete and are incapable of being executed in accordance with the legislative intent.

\section{RHODE ISLAND}

Landrigan v. McElroy, 457 A.2d 1056 (R.I. 1983).

\section{SOUTH CAROLINA}

Thayer v. South Carolina Tax Comm'n, 307 S.C. 6, 413 S.E.2d 810 (1992).

\section{SOUTH DAKOTA}

Simpson v. Tobin, 367 N.W.2d 757 (S.D. 1985).

\section{TENNESSEE}

In Tennessee, there is a stated presumption against severabihty, or, as the Tennessee courts often call it, elision. See, e.g., Vollmer v. City of Memphis, 730 S.W.2d 619, 622 (Tenn. 1987) (stating presumption exists against sustaining remaining part of statute, where part has been declared unconstitutional). But, cf., Lowe's Cos. v. Cardwell, 813 S.W.2d 428, 430 (Tenn. 1991) (explaining that "under the doctrine of elision, a court may, under appropriate circumstances and in keeping with the expressed intent of a legislative body, ehde an unconstitutional portion of a statute and find the remaining provisions to be constitutional and effective").

The "presumption against severabihty" seems to have coalesced in Chief Justice Green's opinion in Heymann v. Hamilton Nat'l Bank, 151 Tenn. 21, 28, 266 S.W. 1043, 1045 (1924), where he wrote: "Some of us do not believe that elision is permissible to save an act otherwise bad under the two-subject clause of the Constitution." Justice Green proceeded to outlime the test for severability: "Certainly elision is not permissible in any case if the result so attained will defeat the legislative intent." Id.

The stated presumption notwithstanding, in practice Tennessee severability law resembles the law of other states. Generally, "where a part of a statute is so 
interwoven with other portions of an act that we cannot suppose that the legislature would have passed the act with that clause omitted, if such clause is declared void it renders the whole act null." Hobbs v. Lawrence County, 193 Tenn. 608, 615, 247 S.W.2d 73, 76 (1952).

Tennessee courts will apply the rule of ehsion if they determine that "the legislature would have enacted [the statute] with the objectionable features omitted, ... provided, of course, there is left enough of the act for a complete law, capable of enforcement and fairly answering the object of its passage." Gibson County Special Sch. Dist. v. Palmer, 691 S.W.2d 544, 551 (1985).

\section{TEXAS}

Association of Tex. Professional Educators v. Kirby, 788 S.W.2d 827 (Tex. 1990). Tex. Gov't CODE ANN. $§ 312.013$ (West 1993) provides:

312.013. Severability of Statutes.

(a) Unless expressly provided otherwise, if any provision of a statute or its application to any person or circumstance is held invalid, the invalidity does not affect other provisions or applications of the statute that can be given effect without the invalid provision or application, and to this end the provisions of the statute are severable.

(b) This section does not affect the power or duty of a court to ascertain and give effect to legislative intent concerning severability of a statute.

\section{UTAH}

Berry ex rel. Berry v. Beech Aircraft Corp., 717 P.2d 670 (Utah 1985).

\section{VERMONT}

Bagley v. Vermont Dep't of Taxes, 146 Vt. 120, 500 A.2d 223 (1985).

\section{VIRGINIA}

Like Tennessee, Virginia courts describe Virginia severability doctrine as a presumption against severability. Paraphrasing the United States Supreme Court's language in Carter v. Carter Coal Co., 298 U.S. 238, 312-13 (1936), quoted with approval in Hannabass v. Maryland Casualty Co., 194 S.E. 808, 813 (Va. 1938), the Virginia Supreme Court in Board of Supervisors v. Rowe, 216 S.E.2d 199 (Va. 1975), described the rule concerning severability:

Absent a severability provision, a legislative act is presumed to be non-severable, and the burden of proving severability is upon the supporter of the legislation. Where a severability provision is included, a legislative act is presumed to be severable, the burden of proving non-severability is on the assailant of the legislation, and the presumption of severability must be overcome by considerations whicl establish the clear probability that the legislature would not have been satisfied with what remains after elimination of the invalid parts.

Id. at 214. Regardless of the presence of a severability provision, "the determi- 
nation, in the end, is reached by applying the same test-namely, What was the intent of the lawmakers?" Hannabass, 194 S.E. at 813.

While the presence of a severability provision provides the Virginia courts with a rule of construction that may sometimes aid in determining legislative intent, " "it is an aid inerely; not an inexorable command.' " Rowe, 216 S.E. at 214 (quoting Dorchy v. Kansas, 264 U.S. 286, 290 (1924)).

Thus, both Tennessee and Virginia determine severability much the same way as do the rest of the states; the only difference is that the starting point is a presumption against severability. In Robinson v. Commonwealth, 232 S.E.2d 742,744 (Va. 1977), the Virginia Supreme Court stated that "the test of severability is whether the legislature would be satisfied with the remainder after the invalid portions have been ehminated; the intent of the legislative body controls."

\section{WASHINGTON}

City of Seattle v. State, 103 Wash. 2d 663, 694 P.2d 641 (1985).

\section{WEST VIRGINIA}

Anderson's Paving, Inc. v. Hayes, 170 W. Va. 640, 295 S.E.2d 805 (1982). The relevant part of West Virgimia's statutory construction provision reads: § 2-2-10 Rules for constructiou of statutes.

The following rules shall be observed in the construction of statutes, unless a different intent on the part of the Legislature be apparent from the context: ...

(cc) Unless there is a provision in a section, article or chapter of this code specifying that the provisions thereof shall not be severable, the provisions of every section, article or chapter of this code, whether enacted before or subsequent to the effective date of this subdivision [March 30,1973], shall be severable so that if any provision of any such section, article or chapter is held to be unconstitutional or void, the remaining provisions of such section, article or chapter shall renrain valid, unless the court finds the valid provisions are so essentially and inseparably connected with, and so dependent upon, the unconstitutional or void provision that the court cannot presume the Legislature would have enacted the remaining valid provisions without the unconstitutional or void one, or unless the court finds the remaining valid provisions, standing alone, are incoinplete and are incapable of being executed in accordance with the legislative intent: Provided, That if any such section, article or chapter of this code has its own severability clause, then such severability clause shall govern and control with respect to such section, article or chapter in lieu of the provisions of this subdivision.

W. VA. CODE § 2-2-10 (1990).

\section{WISCONSIN}

Burlington Northeru, Inc. v. City of Superior, 131 Wis. 2d 564, 388 N.W.2d 916 (1986), cert. denied, 479 U.S. 1034 (1987). Wisconsin has a statutory construction provision which provides: 
In construing Wisconsin laws the following rules shall be observed unless construction in accordance with a rule would produce a result inconsistent with the manifest intent of the legislature:

(11) SEVERABILITY. The provisions of the statutes are severable. The provisions of any session law are severable. If any provision of the statutes or of a session law is invalid, or if the application of either to any person or circuinstance is invalid, such invalidity shall not affect other provisions or applications which can be given effect without the invalid provision or application.

Wisc. Stat. AnN. § 990.001 (West 1985).

\section{WYOMING}

Bell v. Gray, 377 P.2d 924 (Wyo. 1963). 